\title{
1952
}

Miscellaneous Publication No. 952

$9 g 84 m$

U. S. DEPT. OF AGRICULTURE HATIONA! DOM TINAI IIBRARY

$$
\text { Arr } 211964
$$

CURRENI SERIAL REWURDS

\section{LEGUMES AND GRASSES}

in Dryland Cropping Systems

in the Northern and

Central Great Plains

A Review of the Literature

Agricultural Research Service

U.S. DEPARTMENT OF AGRICULTURE

in cooperation with

State Agricultural Experiment Stations 



\section{Historic, archived document}

Do not assume content reflects current scientific knowledge, policies, or practices. 



\title{
LEGUMES AND GRASSES in Dryland Cropping Systems in the Northern and Central Great Plains
}

A Review of the Literature

\author{
By Paul L. Brown
}

Miscellaneous Publication No. 952

Agricultural Research Service

U.S. DEPARTMENT OF AGRICULTURE

in cooperation with the

State Agricultural Experiment Stations of Colorado, Kansas, Montana, Nebraska,

North Dakota, South Dakota, and Wyoming

Washington, D.C. 


\section{CONTENTS}

Review of United States Soil-Management Problems...

General _. .

North Dakota...

South Dakota...

Montana. .

Wyoming

Nebraska

Kansas $-x_{1}$

Colorado

Carbon and Nitrogen Changes in Soils at 10 Dryland Experiment Stations....

Canadian Prairie Provinces Soil-Management Problems. . . . . . . . . . .

Summary and Conclusions

Literature Cited

For sale by the Superintendent of Documents, U.S. Government Printing Office Washington, D.C., 20402 Price 25 cents 


\section{LEGUMES AND GRASSES \\ in Dryland Cropping Systems in the Northern and Central Great Plains}

\section{A Review of the Literature}

By Paul L. Brown, soil scientist, Soil and Water Conservation Research Division, Agriculture Research Service

The purpose of this publication is to review the literature and determine the value of legumes and grasses as soil-conserving and soilimproving crops in the northern and central Great Plains.

This publication summarizes the following experimental data: Comparison of crop yields in rotations with and without legumes and grasses; (2) comparison of legumes versus inorganic sources of nitrogen; (3) soil-moisture use by legumes and grasses; and (4) chemical and physical effects of legumes and grasses on soils. The term "grass," as used in this publication, excludes cereal crops. The terms "carbon" and "organic carbon" have been used as the authors in the source materials used them.

\section{GEOGRAPHICAL AREA}

The northern and central Great Plains includes most of North Dakota and South Dakota, Nebraska, Kansas, eastern Colorado, eastern Wyoming, and eastern Montana. It also includes parts of Alberta, Saskatchewan, and Manitoba (7). ${ }^{1} \quad$ Figure 1 delineates the area under discussion. The experiment stations at Fargo, N. Dak., Lincoln, Nebr., and Manhattan, Kans., are just east of the Great Plains, but pertinent experimental data from these locations were included to show State and regionwide relationships.

\section{REVIEW OF UNITED STATES SOIL-MANAGEMENT PROBLEMS}

\section{General}

Dryfarming problems in the northern and central Great Plains have been discussed frequently in the literature of the 20th century. The advantages and disadvantages of the use of legumes and grasses as soil-improving and soil-conserving crops have been reported.

In 1917, Pieters (66) reviewed all American experiment station liter-

${ }^{1}$ Italic numbers in parentheses refer to Literature Cited, p. 60. ature on the subject of green manuring. This review was to determine the value of legumes as measured by yields of succeeding crops. He reported data from 28 States and Canada. His findings show that the value of legumes as green manures decreased from the Southeastern to Northwestern United States. In the Dakotas and Canadian Northwest, the use of leguminous green-manure crops was not profitable. In this area, greenmanure crops used the moisture needed for the main crop. 


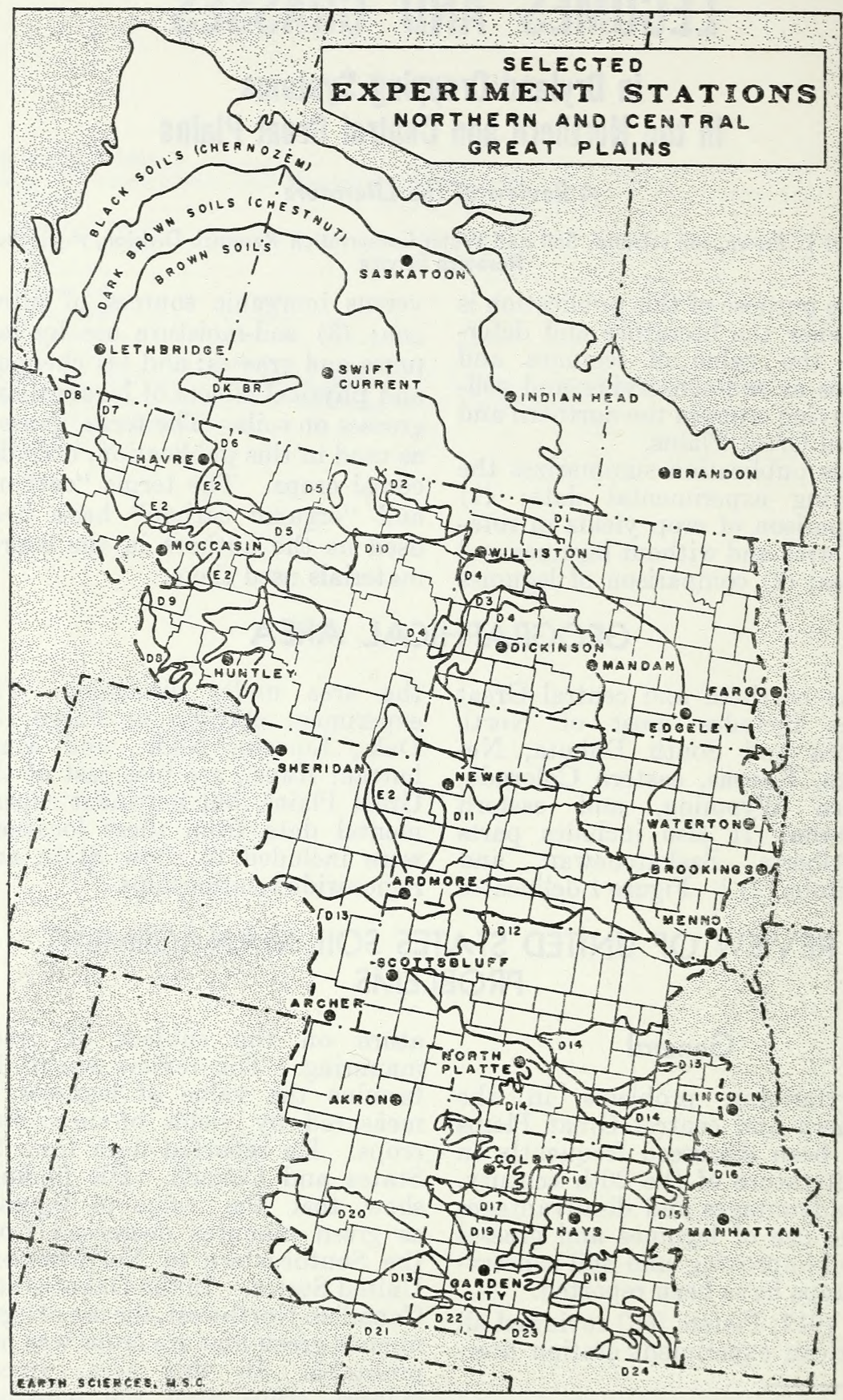

FIGURE 1.-Northern and central Great Plains areas of the United States and Canada, showing problem areas in soil conservation in the United States and great soil groups in Canada (81). See legend on opposite page. 
In 1931, Chilcott (10) stated that the use of biennial and perennial hay and forage crops in rotations was not of major importance in the Great Plains. The conservation and utilization of scanty rainfall was of such predominant importance as to relegate the use of biennial hay and forage crops in rotations to a minor role.

In 1938, Mathews and Cole (52) discussed dryfarming problems in the Great Plains and Intermountain dryland areas. They stated:

Maintenance or increase of the organicmatter content of the soil through the application of manures or green manures will not pay for the cost where crops are grown for grain. Stover yields may be increased enough to justify the added expense.

The inclusion of sod crops in short rotations has not been a success. Establishing a stand of grasses is often too expensive unless it is to be left for more than 2 or 3 years. Further, while the long-time effect of a grass sod may be good, its effect on the crop immediately following is generally bad, because it leaves the soil exceedingly dry.

In 1939, Cole and Mathews (12) reported a study on subsoil moisture conditions under semiarid conditions at Havre, Mont., Mandan, N. Dak., North Platte, Nebr., and Hays and Colby, Kans. This study showed that the depth to

Legend for problem areas in soil conservation (81) shown in figure 1.

Great Plains:

D1 Black Glaciated Plains, Eastern Dakotas

D2 Dark Brown Glaciated Plains, Central Dakotas

D3 Badlands of North Dakota

D4 Residual Plains, West Dakotas

D5 Badlands of Montana

D6 Thinly Glaciated Plains and Scablands

D7 Triangle Area of Montana

D8 Western Montana Foothills and Benches

D9 Central Montana Shale Hills and Plains

D10 Powder-Yellowstone Residual Plains

D11 Pierre Shale Plains

D12 Nebraska Sand Hills

D13 Northern Brown Plains which water penetrated depended on the quantity and type of precipitation and the character of the soil. As a general rule, the annual cycle of water charge and discharge was confined to that part of the zone where roots developed freely and no water reached the underlying substrate. Occasionally, the entire root zone filled with water, and a small quantity of water penetrated beyond reach of plant roots.

In 1944, Jacks (38) discussed the effects of grass on soil. He stated that the most striking effects are related to the physical properties of the soil. Perennial grass, grown in a semiarid temperate climate, was the most efficient producer of granular soil structure. In more arid climates, where grasses grow with difficulty, or in more humid climates, which exert a disintegrating effect on soil structure, granulation was less highly developed. Regardless of climate, perennial grasses were found to be more effective than any other kind of vegetation.

Jacks reported that the full effects that grass had on soil were achieved in 2 years in moist temperate climates and in 4 years in dry temperate climates. Roots are
D14 Nebraska-Kansas Dissected Loess Hills and Tablelands

D15 Central Nebraska-Kansas Loess Plains

D16 Central Kansas Shale-Sandstone Hills and Loess Plains

D17 Breaks of the High Plains

D18 Great Bend Sandy Plains, Arkansas River

D19 Arkansas River Loessial Outwash Plains

D20 Plains of Upper Arkansas and Purgatoire Rivers

D21 Cimarron-Canadian Breaks

D22 Southern High Plains

D23 Red Plains of Kansas, Oklahoma, and Texas

D24 Red Prairies of Kansas, Oklahoma, and Texas

Rocky Mountains:

E2 Outlying mountains of Montana and Black Hills of South Dakota 
the most active part of a grass crop in the formation of soil aggregates. This was demonstrated by the fact that growing perennial grass was much more effective than adding grass clippings or hay to soil.

In 1955, Duley and Coyle (17) discussed dryfarming problems in the United States. They stated that the use of green manures was not effective in improving growth of the succeeding crops. They speculated that benefits might increase after the land had been farmed for a longer time and further experiments determined the most effective methods of using green manures.

Soil-management problems of the United States were discussed by regions in the 1957 Yearbook of Agriculture (33, 63). The United States was divided into 16 regions. Each of the regions had a combination of climate, soils, and agriculture that gave it unique soil-management problems. A brief summary of statements concerning the use of legumes and grasses in the northern and part of the central Great Plains follows:

Northern Great Plains.-Norum, Krantz, and Haas (63) reported that, generally, it was not profitable to plow under sweetclover, peas, or winter rye for green manure and fallow for the rest of the season in the spring wheat subregion, except in years of above-average precipitation. The gains achieved in favorable years were lost in dry years.

Winter Wheat and Grazing Region.-This area includes southwestern Nebraska, eastern Colorado, western three-fourths of Kansas, northwest Oklahoma and Texas, and northeastern New Mexico. Hobbs (33) reported that sweetclover grew well in the more humid areas of the eastern half of Kansas and in Oklahoma east of the Panhandle, but there was little benefit from using sweetclover solely as green manure. Almost as good results were obtained from pasturing it or using it as a hay or seed crop or by omitting the legume entirely (especially in the main wheat areas) and by using nitrogenous fertilizer. Hobbs made no mention of the use of legumes and grasses in the area where summer fallowing is commonly used.

In 1959 , Stickler and coworkers (78) reported on the comparative value of legume green manures and fertilizer nitrogen for corn production in Iowa for 1955-57. They found that the mean cornproducing value of nitrogen from 19 legume green manures, as determined by first- and second-year corn data, was equivalent to 34 and 64 pounds per acre of inorganic nitrogen, respectively. Madrid sweetclover was superior to al] other legumes as a green manure.

\section{Yields}

\section{North Dakota}

Green-manure experiments were conducted at Dickinson, Edgeley, Hettinger, Mandan, and Williston, N. Dak., beginning in $1906(10,13$, $5 \%, 71)$. Yields of spring wheat and oats after green-manure fallow, continuous cropping, and ordinary fallow are presented (table 1 ).

In 1925, Moomaw (57) reported on tillage and rotation experiments at Dickinson, Hettinger, and Williston. Average annual precipitation was 15.4 inches at Dickinson, 14.2 inches at Hettinger, and 14.1 inches at Williston. His findings show that bromegrass and alfalfa were the most productive perennial hay crops for the area, but were of doubtful value in short rotations. Grain yields were not increased by sod crops in the rotation. Stand-establishment difficulties reduced the yields of hay below a profitable point for the period the 


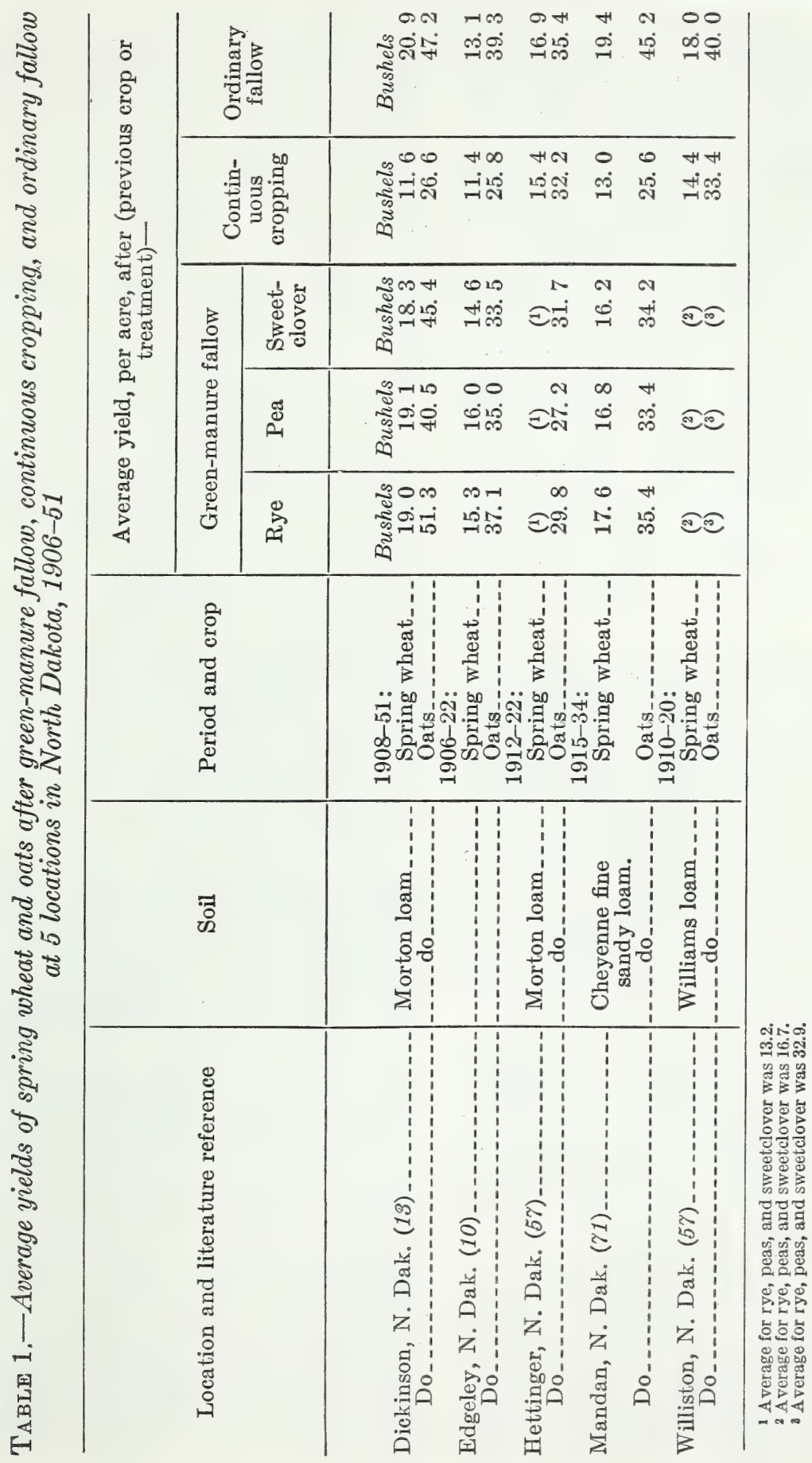


land was occupied. Where a stand was established, he recommended that it be retained for several years rather than being plowed up with the hope of benefiting succeeding grain crops. There was no measured cumulative effect from green manure, and a legume was of no more value than a nonlegume.

In 1931, Chilcott (10) reported on tillage and rotation experiments at Edgeley. The soil at Edgeley is shallow-about 2 feet over shale. This soil has a very limited moisture-storage capacity. Annual precipitation averaged 17.4 inches. Spring wheat yields after greenmanure fallow were 2 to 3 bushels per acre greater than that after ordinary fallow (table 1). Oat yields were lower with green-manure fallow than with ordinary fallow.

In 1936, Sarvis and Thysell (71) reported on crop-rotation and tillage experiments at the Northern Great Plains Field Station at Mandan. Annual precipitation averaged 15.2 inches. Green manuring was a more expensive seedbed preparation than summer-fallowing, and the results with spring wheat to 1934 did not justify this practice (table 1). Alfalfa averaged nearly a ton of hay per acre per year, and bromegrass yielded about half this amount (71).

In 1948, Carpenter (8) reported the effect of organic amendments on crop yields at Mandan. Greenmanure crops increased yields in some years, but the increase did not justify the extra expense. Greenmanure crops had been of no benefit to the soil.

In 1953, Conlon and coworkers (13) reported on rotation and tillage investigations at Dickinson. They found that yields of oats after rye green-manure fallow averaged about 4 bushels per acre more than after ordinary fallow (table 1). How- ever, results to 1951 did not justify the practice of green manuring because of extra costs. Sod crops were unsuited to short rotations because they left the soil in a dry condition. This was reflected in reduced yields of the following grain crops.

In 1955, Haas (24) showed that soil fertility had become limiting for crop production on Cheyenne fine sandy loam at Mandan. $\mathrm{He}$ gave relative yields of wheat and corn for two periods-1915-18 and 1947-53 (table 2).

Annual precipitation averaged 15.7 inches for the first period and 16.7 inches for the last period. During the later period, highest yields were from rotations containing alfalfa or receiving manure. Sweetclover in the rotation with wheat apparently benefited wheat and corn yields. Grass in the rotation did not benefit wheat, but it did improve corn yields. Continuous corn produced the most grain during the first period but least during the last period.

In 1958, Haas and Boatwright ${ }^{2}$ cautioned that spring wheat after grass or legumes at Mandan may suffer from severe moisture deficiency, which counteracts any beneficial effect from the previous sod crop. Corn was considered to be a better crop than wheat after sod.

In a later report, Haas and Boatwright (26) showed that wheat yields after wheat, corn, and greenmanure fallow were all increased to the same yield level at Mandan by adding 80 pounds of $\mathrm{N}$ and 40 pounds of $\mathrm{P}_{2} \mathrm{O}_{5}$. They conducted this experiment on Cheyenne fine sandy loam from 1955 to 1957. Second-year wheat yields were

${ }^{2} \mathrm{H}_{\mathrm{Aas}}, \mathrm{H}$. J., and Boatwright, G. O. GRASS, LEGUME, AND FERTILIZERS AFFECT SPRING WHEAT YIELDS. Northern Great Plains Field Sta., Mandan, N. Dak. [Unpublished Res. Rpt.] 1958. 
TABLE 2.-Relative yields of wheat and corn for two periods of time and loss in soil nitrogen in various rotations, Mandan, N. Dak., 1915-18 and $1947^{7}-53^{1}$

\begin{tabular}{|c|c|c|c|c|c|}
\hline \multirow{3}{*}{ Rotation } & \multicolumn{4}{|c|}{ Relative yield of- } & \multirow{3}{*}{$\begin{array}{c}\text { Loss } \\
\text { in } \\
\text { soil } \\
\text { nitrogen }\end{array}$} \\
\hline & \multicolumn{2}{|c|}{ Wheat } & \multicolumn{2}{|c|}{ Corn } & \\
\hline & $\begin{array}{l}1915 \\
\text { to } \\
1918\end{array}$ & $\begin{array}{c}1947 \\
\text { to } \\
1953^{2}\end{array}$ & $\begin{array}{l}1915 \\
\text { to } \\
1918\end{array}$ & $\begin{array}{c}1947 \\
\text { to } \\
1953\end{array}$ & \\
\hline $\begin{array}{l}\text { Corn, wheat, small grain } \\
\text { Corn, wheat, small grain, grass } \\
\text { Corn, wheat, small grain, sweetclover } \\
\text { Corn, wheat, small grain, alfalfa } \\
\text { Corn, wheat, small grain, manure. } \\
\text { Continuous wheat. } \\
\text { Continuous corn }\end{array}$ & $\begin{array}{r}\text { Percent } \\
100 \\
86 \\
105 \\
110 \\
101 \\
96\end{array}$ & $\begin{array}{r}\text { Percent } \\
100 \\
97 \\
124 \\
140 \\
149 \\
113\end{array}$ & $\begin{array}{r}\text { Percent } \\
100 \\
76 \\
94 \\
97 \\
94 \\
111\end{array}$ & $\begin{array}{r}\text { Percent } \\
100 \\
110 \\
110 \\
123 \\
116 \\
-68\end{array}$ & $\begin{array}{r}\text { Percent } \\
34 \\
30 \\
30 \\
19 \\
3 \\
18 \\
42\end{array}$ \\
\hline
\end{tabular}

1 Data from Haas (24).

24 -year arerage, as 3 years omitted because of hail damage.

doubled by fertilization. Fertilizers were more effective in increasing wheat yields than the use of legumes and grass.

\section{Chemical and Physical Effects of Legumes and Grasses on Soils}

In 1949 , a study was initiated at Mandan on cultivated Cheyenne fine sandy loam and Agar silt loam to determine the effects of legumes and grasses on the maintenance of organic matter and nitrogen. ${ }^{3}$ Fertilizers were applied annually. Sod crops were mowed and the hay removed. Wheat was combined and straw was returned to the soil. The sod was plowed in 1955 . Soil samples were taken in 1949 and 1955. Nitrogen changes for the 0 -

3 HAAS, H. J. FERTILITY MANAGEMENT USE OF LEGUMES AND MANURES FOR THE MAINTENANCE OF ORGANIC MATTER AND NITROGEN, AND SUBSTITUTION OF FERTILIZED CONTINUOUS WHEAT FOR WHEATFALLOW. Paper presented at ARS-SCS Research Application Workshop, Rapid City, S. Dak., Feb. 16-17, 1960. (Mimeo Rpt.)

$711-108-64-2$ to 24-inch depths were measured (table 3).

The data indicate that crested wheatgrass and continuous wheat without fertilization both resulted in nitrogen losses on the fine sandy loam soil; however, these losses were small. Where fertilizers were applied or legumes were grown, small nitrogen increases occurred on both soils. The silt loam soil showed greater nitrogen increases than did the sandy loam soil.

In this same study, one-half of each plot on the Cheyenne soil was mowed and the residue left on the surface from 1949 through 1955. All plots were plowed in 1955 and cropped to spring wheat in 1956 and 1957 ; in 1957 samples of the soil were tested. No fertilizer was applied during 1956 and 1957 except on the continuous-wheat plots that had previously received 30 pounds of both $\mathrm{N}$ and $\mathrm{P}_{2} \mathrm{O}_{5}$. Nitrogen gains and losses for the 0- to 24-inch depths were measured (table 4).

Haas' data indicate that wheat and nonfertilized crested wheat- 
TABLE 3.-Changes in nitrogen content in 0- to 24-inch depths in 2 soils with different rotations and fertilizer treatments, Mandan, N. Dak., $1949-55^{1}$

\begin{tabular}{|c|c|c|c|c|}
\hline \multirow{2}{*}{ Rotation } & \multicolumn{2}{|c|}{$\begin{array}{c}\text { Annual application, } \\
\text { per acre, of - }\end{array}$} & \multicolumn{2}{|c|}{$\begin{array}{l}\text { Gain or loss of } \\
\text { nitrogen in- }\end{array}$} \\
\hline & $\mathrm{N}$ & $\mathrm{P}_{2} \mathrm{O}_{5}$ & $\begin{array}{l}\text { Cheyenne } \\
\text { fine sandy } \\
\text { loam }\end{array}$ & $\begin{array}{l}\text { Agar silt } \\
\text { loam }\end{array}$ \\
\hline Wheat.... & Pounds $_{0}$ & Pounds $_{0}$ & $\begin{array}{l}\text { Percent } \\
-3\end{array}$ & ${ }_{\text {Percent }}^{-3}$ \\
\hline Do & 30 & 30 & +1 & +3 \\
\hline Crested wheatgrass & $\begin{array}{r}0 \\
30\end{array}$ & $\begin{array}{r}0 \\
30\end{array}$ & -1 & +3 \\
\hline Do & 60 & 30 & +1 & $\begin{array}{l}+0 \\
+2\end{array}$ \\
\hline Crested wheatgrass and alfalfa & 0 & 30 & +1 & +3 \\
\hline Crested wheatgrass and sweetclover_- & 0 & 30 & +1 & \\
\hline
\end{tabular}

1 Data from Haas, see footnote 3, p. 7.

TABLE 4.-Changes in nitrogen content in 0- to 24-inch depths of Cheyenne soil with different rotations and fertilizer and harvesting treatments, Mandan, N. Dak., 1949-571

\begin{tabular}{|c|c|c|c|c|}
\hline \multirow{2}{*}{ Rotation, 1949-55 2} & \multicolumn{2}{|c|}{$\begin{array}{c}\text { Annual application } \\
(1949-55) \text {, per acre, } \\
\text { of- }\end{array}$} & \multicolumn{2}{|c|}{$\begin{array}{l}\text { Gain or loss of nitrogen } \\
\text { (1949-57) when } \\
\text { crop was- }\end{array}$} \\
\hline & $\mathrm{N}$ & $\mathrm{P}_{2} \mathrm{O}_{5}$ & $\begin{array}{c}\text { Harvested, } \\
1949-55\end{array}$ & $\begin{array}{l}\text { Not } \\
\text { harvested, } \\
1949-55\end{array}$ \\
\hline $\begin{array}{l}\text { Wheat } \\
\text { Drested wheatgrass } \\
\text { Do } \\
\text { Dood wheatgrass and alfalfa } \\
\text { Crested } \\
\text { Crested wheatgrass and sweetclover.- }\end{array}$ & $\begin{array}{r}\text { Pounds } \\
0 \\
30 \\
0 \\
30 \\
60 \\
0 \\
0\end{array}$ & $\begin{array}{r}\text { Pounds } \\
0 \\
30 \\
0 \\
30 \\
30 \\
30 \\
30\end{array}$ & $\begin{array}{r}\text { Percent } \\
-3 \\
-2 \\
-3 \\
0 \\
+2 \\
+2 \\
+2\end{array}$ & $\begin{array}{r}\text { Percent } \\
-3 \\
-2 \\
-5 \\
+1 \\
+3 \\
+7 \\
+3\end{array}$ \\
\hline
\end{tabular}

1 Data from Haas, see footnote 3, p. 7.

2 All plots cropped to spring wheat in 1956 and 1957.

grass plots showed nitrogen losses. Nitrogen losses were not decreased in the half of each plot on which the residue was left on the surface. Annual applications of 30 pounds of nitrogen on the crested wheatgrass maintained the initial nitrogen content. Sixty pounds of nitrogen produced a slight increase in the nitrogen content of the soil of both harvested and nonharvested plots.

Furthermore, his data show that phosphorus fertilization of mixed crested wheatgrass and alfalfa or sweetclover produced a slight gain 
in soil nitrogen. The nonharvestedplot gains were greater than the harvested-plot gains.

In 1958, Haas (25) reported a 5 -year study on the soil-improving effects of six grasses and alfalfa at Mandan. His study indicates that the total weight of roots increased until the grass stands were about 4 years old. After 4 years, there was little change in total weight of roots. Crested wheatgrass, bromegrass, Russian wildrye, and western wheatgrass produced more root weight than did grean needlegrass and Canada wildrye.

Haas determined root residues $1 \frac{1}{2}, 2 \frac{1}{2}, 3 \frac{1}{2}$, and $4 \frac{1}{2}$ years after the sod was plowed. Less than 25 percent of the grass-root residue remained in the 0 - to 6 -inch depth $2 \frac{1}{2}$ years after plowing. Approximately 500 pounds per acre of threadleaf sedge (Carex filifolia Nutt.) roots were recovered in the upper 12 inches of soil. These roots had persisted in the soil since the land was plowed from sod 35 years earlier. Threadleaf sedge deserves a special study to determine root production, persistence, and effect on soil structure.
In a separate study one manure and seven commercial festilizer treatments were broadcast annually on crested wheatgrass, Russian wildrye, and bromegrass (25). Nitrogen increased root weights of all three species. Phosphorus increased root weights at the 60 pound rate; potassium had no effect. Annual applications of 15 tons of manure had the same effect on root production as 30 pounds of nitrogen.

Nitrogen and carbon changes were measured after 5 years of grass or legumes without fertilization (table 5). Hay crops were removed annually.

Haas' data indicate that there was little change in the nitrogen content of the soil from the 0- to 6 -inch depth under grass or alfalfa. In the 6- to 12-inch depth there were both losses and gains with the grasses. Substantial nitrogen losses from the 12 - to 24-inch depth occurred in all plots. No explanation of this loss was given. Organiccarbon content increased for all depths under all plots of grass and alfalfa except crested wheatgrass and green needlegrass. The in-

TABLE 5.-Changes in nitrogen and carbon contents, by soil depths, after 5 years of grass or alfalfa without fertilization, Mandan, N.Dak. ${ }^{1}$

\begin{tabular}{|c|c|c|c|c|c|c|}
\hline \multirow{2}{*}{ Species } & \multicolumn{3}{|c|}{$\begin{array}{l}\text { Gain or loss of nitrogen } \\
\text { at depth (inches) of- }\end{array}$} & \multicolumn{3}{|c|}{$\begin{array}{l}\text { Gain or loss of carbon at } \\
\text { depth (inches) of- }\end{array}$} \\
\hline & 0 to 6 & 6 to 12 & 12 to 24 & 0 to 6 & 6 to 12 & 12 to 24 \\
\hline $\begin{array}{l}\text { Crested wheatgrass } \\
\text { Green needlegrass } \\
\text { Western wheatgrass. } \\
\text { Canada wildrye } \\
\text { Russian wildrye. } \\
\text { Bromegrass. }\end{array}$ & $\begin{array}{r}\text { Percent } \\
0 \\
-2 \\
+1 \\
0 \\
-2 \\
+2\end{array}$ & $\begin{array}{r}\text { Percent } \\
-6 \\
-5 \\
-2 \\
+2 \\
+7 \\
+9\end{array}$ & $\begin{array}{r}\text { Percent } \\
-6 \\
-7 \\
-8 \\
-5 \\
-7 \\
-11\end{array}$ & $\begin{array}{r}\text { Percent } \\
+4 \\
\quad-1 \\
+1 \\
+1 \\
+3 \\
+5\end{array}$ & $\begin{array}{r}\text { Percent } \\
-4 \\
-2 \\
+2 \\
+4 \\
+12 \\
+18\end{array}$ & $\begin{array}{r}\text { Percent } \\
0 \\
0 \\
+2 \\
+1 \\
+7 \\
+4\end{array}$ \\
\hline Mean_. & 0 & +1 & -7 & +2 & +5 & +2 \\
\hline Alfalfa_- & +1 & +3 & -8 & +2 & +12 & +1 \\
\hline
\end{tabular}

1 Data from Haas (25). 
creases were quite large in the 6- to 12-inch depths under Russian wildrye and bromegrass. Results show that 5 years of grasses and alfalfa were effective in maintaining the nitrogen and carbon content of the surface soil.

Nitrogen and carbon changes were measured 5 years after the sod was plowed (table 6). Corn and small grains were grown during this period.

His data indicate that losses of soil nitrogen, after plowing the sod, occurred in most of the grass plots. The average loss was 3 percent from the 0 - to 12-inch depths and 7 percent from the 12- to 24-inch depths. The net effect of the 10-year period (5 years in sod followed by 5 years in a rotation of corn and small grain) was a slight loss of nitrogen and a slight gain in carbon.

For the alfalfa plots, small nitrogen gains occurred in the 0 - to 12 inch depth and there was a 5 percent loss in the 12- to 24-inch depth. During the same period, losses of soil nitrogen in a rotation of wheat and corn were 6,12 , and 8 percent, respectively, for the three depths. Young and coworkers (84) reported on the laboratory phases of a study to evaluate the effectiveness of 40 years of soil-management practices in maintaining fertility of Fargo clay at Fargo. They compared livestock- and grain-farming systems. The livestock-farm rotation consisted of wheat, clover, oats, and corn. The straw, corn fodder, and clover hay were removed. Manure -7 to 10 tons per acrewas applied before plowing for corn. The grain-farm rotation consisted of wheat, clover, barley, and potatoes. Corn replaced potatoes in 1944. Crop residues and second growth of clover were returned to the soil.

Their findings show that total nitrogen and organic-carbon content of the soil declined in all plots and both rotations. Soil organic carbon and nitrogen declined 27 percent in check plots and 20 percent in residue and manure plots. Results indicated that four times the amount of manure or residue now being returned to the soil may

TABLE 6.-Changes in nitrogen and carbon contents, by soil depths, 5 years after grass and legumes were plowed, Mandan, N. Dak. ${ }^{1}$

\begin{tabular}{|c|c|c|c|c|c|c|}
\hline \multirow{2}{*}{ Species or rotation } & \multicolumn{3}{|c|}{$\begin{array}{l}\text { Gain or loss of nitrogen } \\
\text { at depth (inches) of- }\end{array}$} & \multicolumn{3}{|c|}{$\begin{array}{l}\text { Gain or loss of carbon } \\
\text { at depth (inches) of- }\end{array}$} \\
\hline & 0 to 6 & 6 to 12 & 12 to 24 & 0 to 6 & 6 to 12 & 12 to 24 \\
\hline $\begin{array}{l}\text { Crested wheatgrass } \\
\text { Western wheatgrass_- } \\
\text { Canada wildrye....- } \\
\text { Russian wildrye....- } \\
\text { Bromegrass._. }\end{array}$ & $\begin{array}{r}\text { Percent } \\
-6 \\
0 \\
-2 \\
0 \\
-5 \\
\end{array}$ & $\begin{array}{r}\text { Percent } \\
-8 \\
+1 \\
-5 \\
-6 \\
+1 \\
\end{array}$ & $\begin{array}{r}\text { Percent } \\
-4 \\
-6 \\
-8 \\
-12 \\
-6 \\
\end{array}$ & $\begin{array}{r}\text { Percent } \\
-7 \\
+1 \\
+2 \\
+1 \\
-6 \\
\end{array}$ & $\begin{array}{r}\text { Percent } \\
-6 \\
0 \\
-2 \\
-4 \\
+4 \\
\end{array}$ & $\begin{array}{r}\text { Percent } \\
+1 \\
+1 \\
+3 \\
-6 \\
+2 \\
\end{array}$ \\
\hline Mean_ & -3 & -3 & -7 & -2 & -2 & 0 \\
\hline $\begin{array}{l}\text { Alfalfa } \\
\text { Wheat, corn }\end{array}$ & $\begin{array}{l}+1 \\
-6\end{array}$ & $\begin{array}{r}+4 \\
-12\end{array}$ & $\begin{array}{l}-5 \\
-8\end{array}$ & $\begin{array}{l}+2 \\
-4\end{array}$ & $\begin{array}{l}+12 \\
-14\end{array}$ & $\begin{array}{l}-3 \\
-2\end{array}$ \\
\hline
\end{tabular}

1 Data from Haas (25). 
be required to reduce the carbon and nitrogen losses to zero. Residues and manure were equally effective in the long-term maintenance of soil nitrogen and carbon contents. Manure applications were approximately equal to the manure that would have been produced by feeding the corn, oats, and clover raised on the land.

Physical soil measurements did not show any important changes in Fargo clay that could be related to past management practices. Tilth apparently had not declined enough in any of the plots to limit yields, as evidenced by high yields of corn, wheat, oats, and barley when treated with adequate amounts of nitrogen and phosphorus fertilizer. Since soil tilth had not deteriorated to any extent on Fargo clay, the authors postulated that poor tilth would be a minor problem in coarser textured cultivated soils under Fargo climatic conditions.

\section{Summary}

Legumes and grasses used as green manures and hay or pasture crops frequently depressed yields of crops that immediately followed, owing to the dry soil conditions in which the legumes and grasses left the soil.

Nitrogen-fertilized grasses generally increased the nitrogen and carbon content of the soil to some extent. Unfertilized grass maintained nitrogen and carbon. Legumes added some nitrogen and carbon.

Nitrogen fertilizer appeared to be more efficient than legumes in increasing crop yields.

Use of manure and crop residues on Fargo clay soil reduced the rate of loss of plant-available nitrogen and phosphorus. Data indicated that about four times the residue now being returned to the soil would be needed to maintain car- bon and nitrogen contents of the Fargo soil.

\section{Yields}

\section{South Dakota}

Green-manure experiments were started at Newell and Ardmore, S. Dak., in 1909 and 1913, respectively $(11,51,65)$. Yields of wheat and oats after green-manure fallow, continuous cropping, ordinary fallow, alfalfa, and bromegrass are presented (table 7).

In 1927, Cole and coworkers (11) reported that green-manure fallow and ordinary fallow produced similar yields of spring wheat at Ardmore (table 7). Green-manure fallow lowered yields of winter wheat. In 1937, Mathews and Clark (51) reported that oats on green-manure fallow produced lower grain yields than on ordinary fallow (table 7). No cumulative benefit from plowing under green-manure crops was shown. Any increase in fertility brought about by plowing under a green-manure crop was counterbalanced by the loss of moisture in producing the green manure. Annual precipitation averaged 15.8 inches at Ardmore.

Two grain crops, oats and flax, were grown on land plowed out of alfalfa, bromegrass, and clover for a 20-year period (51). Yields of oats after alfalfa, bromegrass, and sweetclover averaged 20, 23, and 27 bushels per acre, respectively (table 7). Yields of oats after fallow and continuous cropping averaged 38 and 23 bushels per acre, respectively. Average yield of oats after any sod crop was less than that after fallow-the reduction in yield being especially sharp after alfalfa and bromegrass. These two crops left the soil so dry that the succeeding crop suffered from drought.

Depressing effect on crops after sod sometimes extended into the 
12 MIISCELLANEOUS PUBLICATION 952 , U.S. DEPT. OF AGRICULTURE

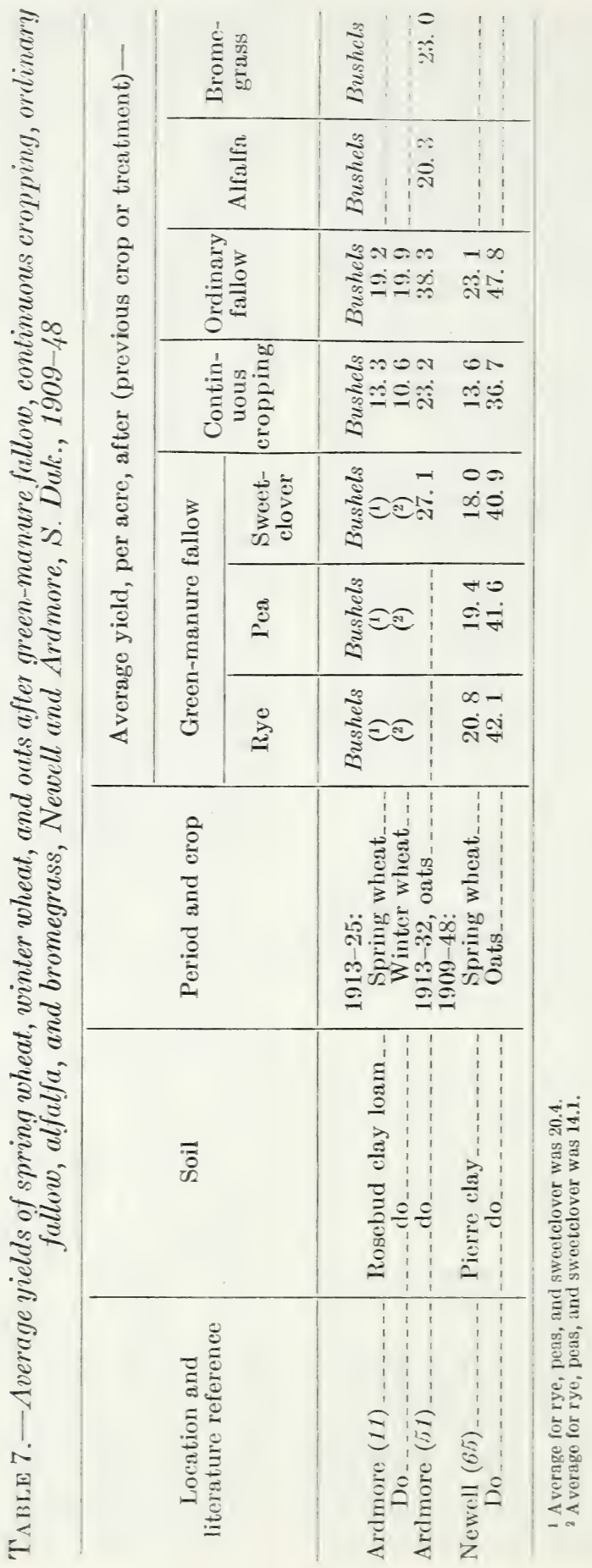


second and third year. These workers concluded that sod crops were of no value in short rotations.

In 1951, Osenbrug and Mathews (65) discussed dryland crop production at the Belle Fourche Field Station at Newell for the previous 40 years. Annual precipitation averaged 16.1 inches. The soil was initially low in organic matter and nitrogen and subject to wind erosion.

Their data indicate that 40-year average yields (table 7) of both wheat and oats were higher on unmanured fallow than immediately after green-manure fallow. Yields on green-manure fallow were generally higher than on ordinary fallow in good seasons. In unfavorable years, the green-manure crop depleted soil moisture so that the succeeding crop was more subject to drought damage.

\section{Legumes Versus Inorganic Nitrogen Sources}

In 1957, Worzella and coworkers (83) published a progress report on research in crops and soil on the Agronomy Farm at Brookings, S. Dak. They had started new rotations in 1954 to compare legumes as a source of nitrogen with nitrogen fertilizer. They tabulated data on yields of corn in 1955 and 1956 and oats in 1956 (table 8).

In 1955, corn yields were limited by July drought. Mature sweetclover plowed under the previous year produced the lowest corn yields (table 8). Twenty pounds of nitrogen on the nonlegume rotation prodüced the highest corn yield. In 1956, mature sweetclover and alfalfa plowed under the previous year produced the highest corn yields. The greatest oat yields were produced with 20 pounds of nitrogen per acre.

In 1957, the Agronomy and Plant Pathology Departments of the South Dakota Agricultural Experiment Station initiated experimental work at two new research farms (72, 73). The Southeast Research Farm was located near Menno in Hutchinson County. The soil is loam and clay loam in association with alkali claypans. Annual precipitation averaged 23.8 inches. The Northeast Research

TABLE 8.-Yields of corn and oats in various rotations and with legumes as source of nitrogen and with nitrogenous fertilizer, Brookings, S. Dak., $1955-56^{1}$

\begin{tabular}{|c|c|c|c|c|}
\hline \multirow{3}{*}{ Rotation } & \multirow{3}{*}{$\begin{array}{l}\text { Nitrogen } \\
\text { added } \\
\text { per acre }{ }^{2}\end{array}$} & \multicolumn{3}{|c|}{ Yield, per acre, of- } \\
\hline & & \multicolumn{2}{|c|}{ Corn } & \multirow{2}{*}{$\begin{array}{l}\text { Oats, } \\
1956\end{array}$} \\
\hline & & 1955 & 1956 & \\
\hline $\begin{array}{l}\text { Corn, oats, flax, wheat } \\
\text { Corn, oats, flax, sweetclover } \\
\text { Corn, oats, flax, mature sweetclover } \\
\text { Corn, oats, flax, sweetclover } \\
\text { Corn, oats, flax, wheat } \\
\text { Do } \\
\text { Do } \\
\text { Corn, flax, alfalfa, alfalfa }\end{array}$ & $\begin{array}{r}\text { Pounds } \\
0 \\
0 \\
0 \\
30 \\
20 \\
40 \\
60 \\
0\end{array}$ & $\begin{array}{r}\text { Bushels } \\
31.7 \\
22.9 \\
15.9 \\
33.2 \\
39.8 \\
35.8 \\
32.9\end{array}$ & $\begin{array}{r}\text { Bushels } \\
62.5 \\
61.7 \\
67.4 \\
62.6 \\
63.2 \\
62.3 \\
60.8 \\
67.0\end{array}$ & $\begin{array}{r}\text { Bushels } \\
33.6 \\
27.6 \\
28.5 \\
41.2 \\
45.3 \\
38.3 \\
30.8\end{array}$ \\
\hline
\end{tabular}

1 Data from Worzella and coworkers (83).

2 Annual applications for the grain crops. 
Farm was located near Watertown in Codington County. The soil is Kranzburg silt loam. Annual precipitation averaged 20.5 inches.

At the two locations, experiments were designed to compare use of legumes and commercial nitrogen as a means of increasing crop yields. These experiments were designed to run for 5 to 8 years. At this writing (1963), only progress reports have been issued. Definite conclusions cannot be made until more data have been collected. Results seem to indicate that, in favorable years, legume and inorganic nitrogen are about equally effective in increasing crop yields $(42,43,72,73,74,75)$. In less favorable years, inorganic nitrogen is more effective. In dry years, a preceding legume crop may reduce yields of grain crops.

Puhr and coworkers (68) reported the results of 1957 soil-fertility experiments conducted on representative soil types in the major crop areas of the State. This study included comparisons of legumes and commercial nitrogen fertilizers as sources of nitrogen at Brookings, Plankinton, and Redfield.

At Brookings, on Vienna loam, sweetclover as the nitrogen source produced significantly greater corn yields than did 20,40 , or 60 pounds of nitrogen fertilizer per acre in 1957. Twenty pounds of nitrogen was approximately equivalent to a sweetclover crop in increasing oat yields.

At Plankinton, on Cavour silty clay loam (solodized-Solonetz), nitrogen from manure or commercial form was more effective for increasing yields of spring wheat than nitrogen supplied by growing greenmanure crops in alternate years. Ordinary fallow produced as good vields of winter wheat as sweetclover fallow. Yields of corn after alfalfa tended to be reduced as compared with those after other treatments, because alfalfa depleted subsoil moisture.

At Redfield, experiments were conducted on nonirrigated and irrigated land (21). Soils at Redfield are Beotia loam and Harmony silty clay loam (82). Nitrogen was more effective than alfalfa in increasing wheat yields on nonirrigated land (table 9). A combination of alfalfa and nitrogen produced the greatest wheat yields.

\section{Chemical and Physical Effects of Legumes and Grasses on Soils}

Sod crops, in rotations at Newell, had a beneficial physical effect on Pierre clay for a temporary period (65). Land in sod rotations was

TABLE 9.-Yields of spring wheat in 2 rotations, with and without nitrogenous fertilizer, Redfield. S. Dak., 1949-53 ${ }^{1}$

\begin{tabular}{|c|c|c|c|}
\hline \multirow{2}{*}{ Rotation } & \multicolumn{2}{|c|}{$\begin{array}{l}\text { Yield, per acre, of spring } \\
\text { wheat with - }\end{array}$} & \multirow{2}{*}{$\begin{array}{l}\text { Increase } \\
\text { with use of } \\
\text { nitrogen }\end{array}$} \\
\hline & No nitrogen & $\begin{array}{l}30 \text { pounds of } \\
\text { nitrogen }\end{array}$ & \\
\hline $\begin{array}{l}\text { Corn, wheat, alfalfa, alfalfa } \\
\text { Corn, wheat........... }\end{array}$ & $\begin{array}{r}\text { Bushels } \\
20.4 \\
14.9\end{array}$ & $\begin{array}{r}\text { Bushels } \\
25.6 \\
22.6\end{array}$ & $\begin{array}{r}\text { Percent } \\
25.5 \\
51.6\end{array}$ \\
\hline Increase with alfalfa, percent & 36. 9 & 13. 3 & - \\
\hline
\end{tabular}

Data from Fine and Campbell (21). 
more friable and worked into a seedbed more readily. This physical effect disappeared almost completely after about 4 years. Land that had recently been in sweetclover was especially susceptible to wind erosion. Sod crops left the land exceedingly dry and often decreased the yields of succeeding crops. When used in deferred rotations with the land cultivated for longer periods between sod crops, yields of other crops were not reduced but were increased occasionally in years of favorable precipitation. This was particularly true in rotations with alfalfa. The authors concluded that alfalfa and grasses had a definite place on any livestock farm but their place was not in short rotations. When used, it was recommended that alfalfa and grasses be left in production several years.

In 1956, Puhr and Worzella (69) outlined a recommended program for management of South Dakota soils. This included the use of legume and grass rotations, with phosphorus applied to the legumes, nitrogen to the grasses, and nitrogen and phosphorus to small grains and corn.

Westin and coworkers (82) reported that water erosion was serious on sloping lands in eastern South Dakota. Erosion was best controlled by increasing the percentage of legumes and grasses in the cropping sequence.

\section{Summary}

Green manures were of little benefit in western South Dakota.

At Ardmore and Newell, bromegrass and alfalfa depressed the yields of crops that immediately followed because of the dry condition in which they left the soil. Grasses and legumes are valuable crops on any livestock farm. They should be grown for several years rather than used in short rotations.
Sod crops had an observed beneficial effect on Pierre clay for about 3 years after plowing. Land was more friable and worked into a seedbed more readily. Quantitative measurements on physical improvement were not made. Recently plowed sweetclover land was observed to be especially susceptible to wind erosion.

Although experimental data were limited, commercial nitrogen appeared to be more efficient in crop production than legume nitrogen in the eastern part of South Dakota. There were exceptions to the foregoing statement, however.

Legumes and grasses are an effective means of decreasing serious water erosion on the sloping lands of eastern South Dakota.

\section{Yields}

\section{Montana}

Green-manure experiments were started at Havre, Mont., in 1917, Moccasin, Mont., in 1909, and Huntley, Mont., in 1913 (1, 2, 28). Yields of several crops after greenmanure fallow, continuous cropping, ordinary fallow, alfalfa, and bromegrass are presented (table 10). Annual precipitation for Havre, Moccasin, and Huntley averaged 13.1, 14.0, and 13.4 inches, respectively.

In 1933, Hansen and coworkers (28) reported on dryland crop yields at Huntley Field Station for 191330. Oat yields after green-manure fallow were less than after ordinary fallow.

Seedbeds prepared by plowing green-manure crops were invariably rougher and more difficult to till than those prepared by stubble plowing in the spring for ordinary fallow. Turning under sweetclover and peas after the soil was dry usually resulted in the seedbed having large clods that were not satisfactorily broken up by planting 


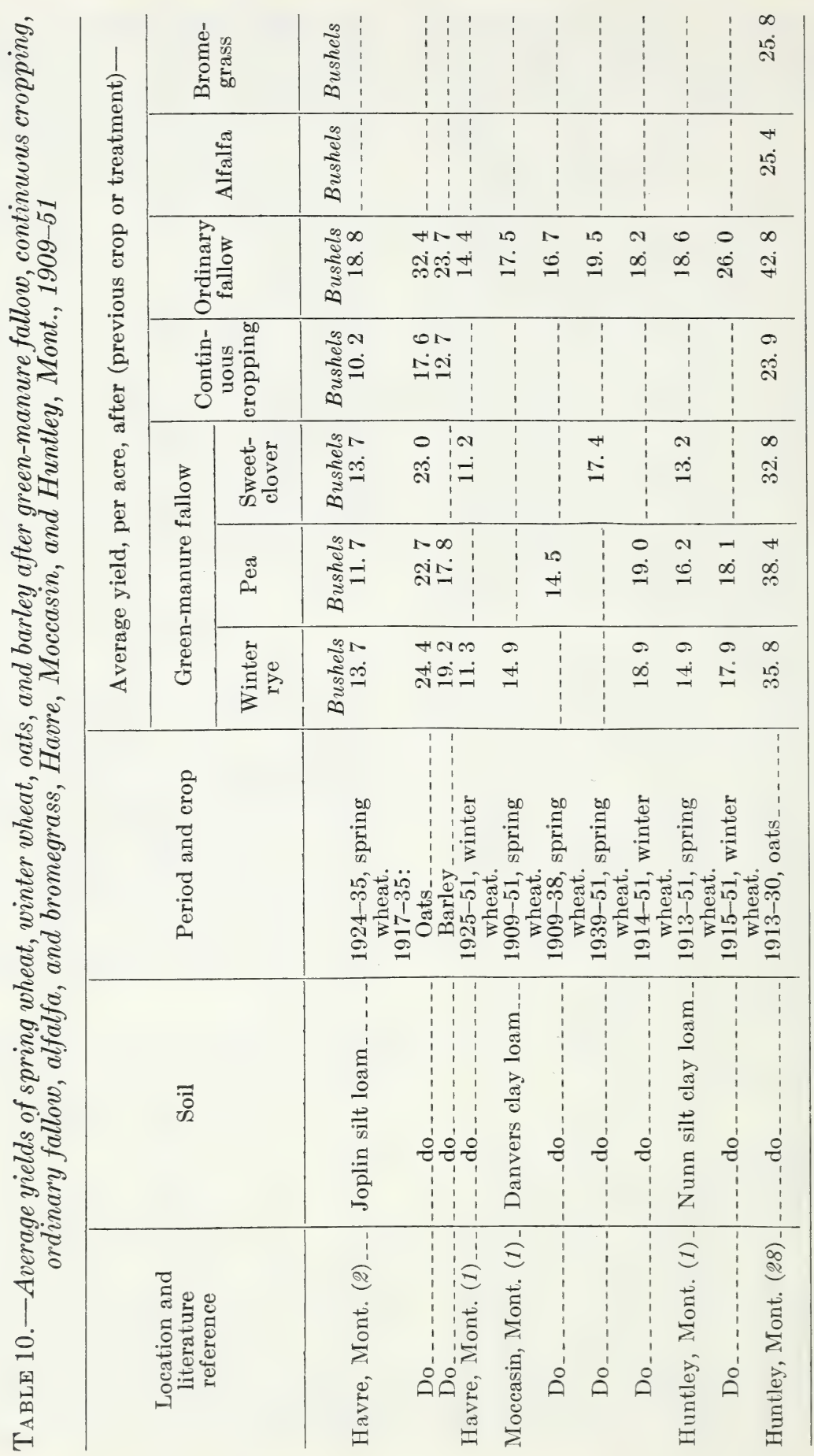


time the following spring. Green manuring had no beneficial effects on the second- and third-year crops.

In 1937, Bell (2) reported on dryland crop investigations at the North Montana Branch Station at Havre. Winter rye, pea, and sweetclover green manures had a depressing effect on yields of small grains the following year compared with ordinary fallow (table 10).

In 1959, Army and Hide (1) reported on the effects of greenmanure crops on dryland wheat production at Havre, Huntley, and Moccasin for 28- to 43-year periods. They found that, compared with ordinary fallow, green-manure fallow crops of winter rye, field peas, and sweetclover decreased yields of spring wheat at Havre, Huntley, and Moccasin an average of 3.2 , 3.6 , and 3.8 bushels per acre, respectively. At Huntley, from 1913 to 1951, yields of winter wheat were decreased 8 bushels per acre by green-manure fallow. At Moccasin, from 1909 to 1951 , yields of winter wheat were increased 0.7 bushel per acre by green-manure fallow.

In 1956, Post and Army (67) examined dryland fallow spring wheat yields to determine whether or not productivity had declined with time. They compared yields for the first 10 years of cultivation at Havre, Huntley, and Moccasin with those for a later 10-year period (1942-51). The yields increased with time at Havre and Huntley-from 14 to 18 bushels per acre at Havre and from 16 to 17 at Huntley. The yields decreased at Moccasin-from 19 to 16 bushels per acre. Rainfall from seeding to harvest was 6.5 inches at Havre and Huntley and 8.4 inches at Moccasin for both periods. Soils at Havre and Huntley are deep; the soil at Moccasin is shallow over gravel.
Windecker and Geeseman ${ }^{4}$ found that crested wheatgrass in rotation was beneficial. Two rotations were used for comparison - crested wheatgrass for 8 years, flax, fallow, spring wheat, oats; and fallow, spring wheat, oats.

From 1947 to 1957, yields of spring wheat in the crested wheatgrass rotation were increased 4.2 bushels per acre and oat yields 7.5 bushels per acre.

Crested wheatgrass hay reached peak production of one-half ton per acre in the second and third year and then gradually declined each year. Flax yields were lowan average of 2.9 bushels per acre.

In spite of increased wheat and oats yields in the grass rotation, the low yields of flax and hay made this an unproductive rotation. The year of fallow prior to the wheat and oats probably removed the deleterious effect of depleted soil moisture that is characteristic of sod crops.

\section{Chemical and Physical Effects of Legumes and Grasses on Soils}

In 1959, Army and Hide (1) reported the carbon and nitrogen analyses of the 0 - to 12 -inch depths of soil from the green-manure study at Havre, Huntley, and Moccasin. Green-manure crops of winter rye, field peas, and sweetclover had not materially affected the nitrogen and carbon contents of the soil. They suggested that green manures should not be used for dryland spring and winter wheat production on soils of the Brown and Chestnut Great Soil Groups.

1 Windecker, Claude, and GeeseMAN, G. E. SUMMARY REPORT OF AGRONOMY, SOILS AND HORTICULTURE RESEARCH WORK AT THE NORTH MONTANA BRANCH station, havre, Mont. Mont. Agr. Expt. Sta. [Mimeo. Rpt.] 1957. 


\section{Summary}

Green-manure fallow reduced the yields of all small-grain crops below those for ordinary fallow at Havre and Huntley. At Moccasin, greenmanure fallow depressed the yield of spring wheat but slightly increased the yield of winter wheat. The yield increase of winter wheat was not enough to pay for the extra cost of the green-manure crop. Green-manure crops did not materially affect the nitrogen or carbon content of the soil.

Eight years of crested wheatgrass in a 12-year rotation increased spring wheat and oats yields to some extent at Havre. Low hay and flax yields more than offset the wheat and oat yield increases.

\section{Yields}

\section{Wyoming}

Green-manure experiments were started at Archer, Wyo., in 1913 $(10,61)$ and Sheridan, Wyo., in $1917 .^{5}$ Yields of several crops after green-manure fallow, continuous cropping, and ordinary fallow are presented in table 11.

In 1925, Towle (79) reported on the work of the Sheridan Field Station. Annual precipitation averaged 15.1 inches. He discussed two sod-crop rotations, one with alfalfa and one with bromegrass. Both were 6-year rotations with the sod occupying the land half the time. Yields of the other crops in these two rotations did not differ from those in other rotations that did not include alfalfa or bromegrass.

In 1931, Chilcott (10) found that spring wheat on pea green-manure fallow yielded the same as ordinary fallow while rye green-manure fallow yielded less. Oats on pea greenmanure fallow outyielded ordinary fallow by 2 bushels per acre.

5 Barnes, O. K. EFFECT OF GREen MANURE AND BARNYARD MANURE ON soIls AND CROPS. Wyo. Agr. Expt. Sta. [Unpublished Res. Rpt.] 1954.
Nelson (61) reported yields of winter wheat for the Archer station for 1914-47. Annual precipitation averaged 15.8 inches. Rye and peas for green-manure fallow produced essentially the same yields as ordinary fallow (table 11).

At Sheridan, Barnes ${ }^{5}$ found that winter wheat on sweetclover greenmanure fallow and oats on rye green-manure fallow produced essentially the same yields as on ordinary fallow (table 11). Wheat yields on rye and pea green-manure fallows were reduced.

\section{Summary}

Green-manure fallow decreased or had no effect on yields of oats and winter wheat at Sheridan and on those of winter wheat and spring wheat at Archer.

Alfalfa and bromegrass, in a 6year rotation at Sheridan, did not increase yields of other crops in the rotation.

\section{Yields}

\section{Nebraska}

Green-manure experiments were initiated at North Platte, Nebr., in 1907 and Scottsbluff, Nebr., in $1912(85,86)$. Yields of several crops after green-manure fallow, continuous cropping, ordinary fallow, alfalfa, and bromegrass are presented (table 12).

In 1923, Zook (85) summarized the initial 10 years of data from dryland crop rotations at Scottsbluff. Annual precipitation averaged 14.0 inches. Pea and rye green-manure fallows depressed yields below those of ordinary fallow (table 12). The author concluded that there was no justification for green manuring in the Scottsbluff area. Green manuring: depressed yields and increased the cost of seedbed preparation. 
LEGUMES AND GRASSES

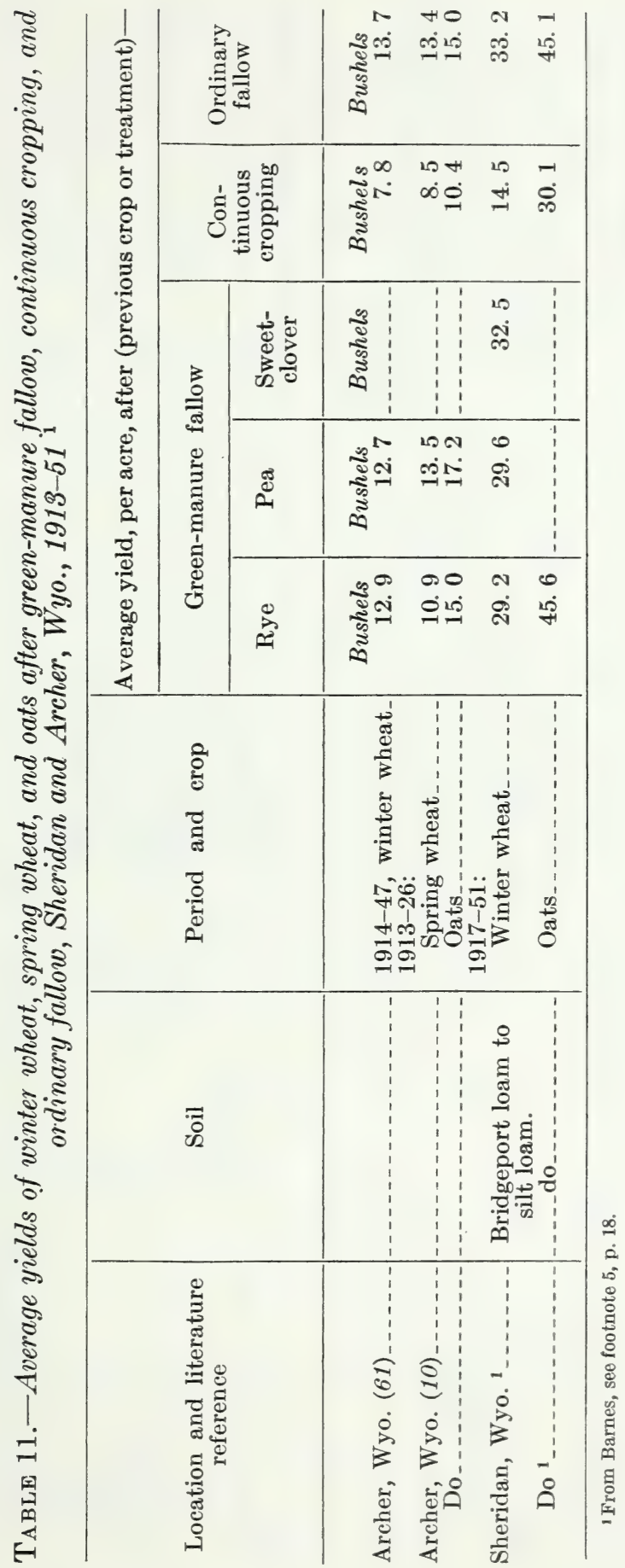


20 Miscellaneous PUblication 952 , U.S. DEPT. OF AGRiculture

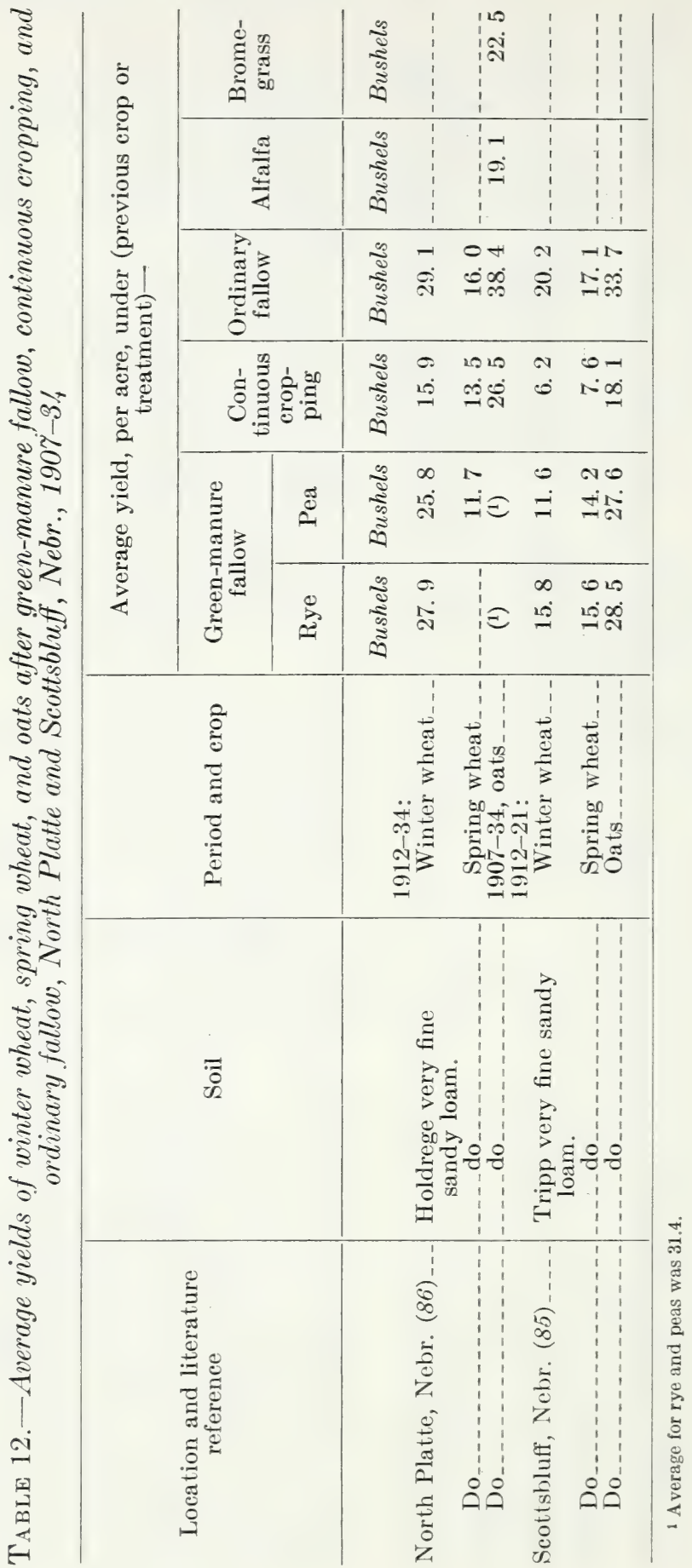


Zook and Weakley (86) reported on crop-rotation and tillage experiments at North Platte for 1907-34 (table 12). Annual precipitation averaged 18.9 inches.

Their data on responses of winter wheat immediately after greenmanure fallow and ordinary fallow and 3 years afterward are presented (table 13).

They found that yields of winter wheat immediately after greenmanure fallow averaged lower than those after ordinary fallow. Rye and peas for green-manure fallow were plowed in May and June, respectively, and the land was fallowed the rest of the year. Ordinary fallow was tilled as soon as spring weed growth started. Part of the moisture used to produce the green-manure crops was stored in the clean fallow. This additional moisture accounted for the higher wheat yields after fallow than after the green-manure crops. The greater yield after rye compared with peas was owing to more moisture being conserved by the earlier plowing date for rye.
However, 3 years later, they found that winter wheat yields after green manures were slightly higher than those after ordinary fallow. Moisture differences had been equalized by the intervening crops. Differences in favor of green manures were greatest when the yields were highest.

Another experiment by Zook and Weakley (86) showed the effects of green manuring on yields of winter wheat grain and straw. For 10 years one plot was clean fallowed and a second plot was seeded to rye each year and plowed under for green manure. Winter wheat was grown continuously on these plots for the following 12 years. The average yield of straw was 44 percent higher on the green-manure plot than on the fallowed plot. Average yields of grain were the same. Increased grain yields on the green-manure plot in years of favorable moisture were offset by decreased yields in dry years when the stimulated early growth of straw on the green-manured soil exhausted soil moisture before the

TABLE 13.-Average yields of winter wheat immediately after and 3 years after ordinary fallow and green-manure fallow, North Platte, Nebr., $1912-34^{1}$

\begin{tabular}{|c|c|c|c|}
\hline \multirow[b]{2}{*}{ Cropping treatment } & \multicolumn{3}{|c|}{$\begin{array}{l}\text { Average yield, per acre, of winter wheat } \\
\text { for- }\end{array}$} \\
\hline & $1912-34$ & $\begin{array}{l}8 \text { high- } \\
\text { yielding } \\
\text { years }\end{array}$ & $\begin{array}{l}8 \text { low- } \\
\text { yielding } \\
\text { years }\end{array}$ \\
\hline & Bushels & Bushels & Bushels \\
\hline \multicolumn{2}{|l|}{ Immediately after: } & & \\
\hline $\begin{array}{l}\text { Ordinary fallow } \\
\text { Rye green-manure fallow }\end{array}$ & $\begin{array}{l}29.1 \\
27.9\end{array}$ & & \\
\hline Pea green-manure fallow & 25.8 & & \\
\hline \multicolumn{4}{|l|}{3 years after: } \\
\hline Rye green-manure fallow & 17. 7 & 34. 3 & 13. 9 \\
\hline Pea green-manure fallow & 17. 4 & 36.3 & 10.8 \\
\hline
\end{tabular}

1 Data from Zook and Weakley (86). 
TABLE 14.-Average yields of wheat and corn in various 12-year rotations, North Platte, Nebr., 1937-59 ${ }^{1}$

\begin{tabular}{|c|c|c|c|c|c|c|}
\hline \multirow{3}{*}{ Rotation } & \multicolumn{6}{|c|}{ Average yield, per acre, in- } \\
\hline & \multicolumn{3}{|c|}{ First cycle } & \multicolumn{3}{|c|}{ Second cycle } \\
\hline & Wheat & Corn & Wheat & Wheat & Corn & Wheat \\
\hline $\begin{array}{l}4 \text { years weeds }{ }^{2} \\
4 \text { years bromegrass }{ }^{2} \\
4 \text { years sweetclover }{ }^{2} \\
\text { Check }^{3}\end{array}$ & $\begin{array}{r}\text { Bushels } \\
32 \\
29 \\
27 \\
29\end{array}$ & $\begin{array}{r}\text { Bushels } \\
32 \\
31 \\
32 \\
24\end{array}$ & $\begin{array}{r}\text { Bushels } \\
14 \\
13 \\
14 \\
12\end{array}$ & $\begin{array}{r}\text { Bushels } \\
30 \\
32 \\
29 \\
29\end{array}$ & $\begin{array}{r}\text { Bushels } \\
29 \\
32 \\
31 \\
27\end{array}$ & $\begin{array}{r}\text { Bushels } \\
12 \\
12 \\
12 \\
12\end{array}$ \\
\hline
\end{tabular}

1 Data from Ramig, see footnote 6, below.

2 Rotations included 4 years of weeds, bromegrass, or sweetclover followed by 8 years of fallow, wheat, corn, and wheat.

3 Fallow, wheat, corn, wheat rotation.

grain was mature. Each year the straw production was greater on the 10-year green-manured plot than that on the 10-year fallowed plot.

After 10 years of continuous green manuring and fallowing, the green-manure plot, at the 0 - to 12 inch soil depth, had 42 percent greater carbon content and 19 percent greater nitrogen content than the fallow plot.

In 1960, Ramig ${ }^{6}$ reported the yields of wheat and corn (table 14) in rotations containing sweetclover, bromegrass, and weeds at North Platte. The soil was HoldregeGoshen silt loam.

His data indicate that wheat yields after fallow during the first cycle were highest after weeds and lowest after sweetclover. Abundant nitrogen from the sweetclover resulted in vegetative overstimulation and decreased grain yields when the moisture supply was exhausted before maturity. Corn yields were notably lower for the

${ }^{6}$ Ramig, R. E. CONSERvation CropPING SYSTEMS FOR THE CENTRAL GREAT PLAINs. Paper presented at ARS-SCS Research Application Workshop, Rapid City, S. Dak., Feb. 16-17, 1960. (Mimeo. Rpt.) check treatment. Results to 1959 indicated that grasses and legumes in dryland rotations have little effect on grain yields. Wheatprotein data indicated temporary increases in soil nitrogen after sweetclover.

\section{Legume Versus Inorganic Nitrogen Sources}

Kiesselbach and Lyness (40) reported the results of crop-rotation experiments at Lincoln for 1942-51. The soil was Sharpsburg silty clay loam. When these experiments were initiated in 1933, lime and commercial fertilizer were not included as treatments.

In 1951, all the grain plots except barley were divided in half in four of the rotations. One-half of each plot was topdressed with nitrogen at the rate of 40 pounds per acre. These plots had never been limed.

The 40-pound application of nitrogen increased the yields of all crops except the manured-wheat crops (table 15). Data indicated that sweetclover did not supply adequate nitrogen for any crop in the 6-year rotations. Results (table 15) might have been different had lime been used. A nearby 
experiment showed that lime was needed for optimum sweetclover growth, which in turn would have added to soil productivity for following crops. Other experiments in the Corn Belt indicate that 40 pounds of nitrogen probably was not sufficient for optimum production of corn in this experiment. The authors indicated that the amount of supplementary nitrogen needed for most profitable production varied with growth and frequency of the legume in the rotation.

\section{Soil Moisture Use by Legumes and Grasses}

In 1929, Kiesselbach and coworkers (41) reported that the productivity of alfalfa meadows declined abruptly 4 to 5 years after seeding at Lincoln, even though a good stand remained. This was attributed to depletion of subsoil moisture. A 2-year stand of alfalfa used subsoil moisture to a depth of 25 feet. A 6-year stand used moisture to 33 feet. Annual precipitation averaged 27.8 inches.

Their findings show that, with ordinary cropping, natural restoration of subsoil moisture after alfalfa was very slow. During 15 years of cropping to cereal crops after plowing an established alfalfa meadow, very little moisture accumulated below the 7-foot level. This indicated that cereal crops after alfalfa used all precipitation and no water was stored in the deep subsoil or lost to percolation at Lincoln.

In 1934, Kiesselbach and coworkers (39) reported on restoration of subsoil moisture at Lincoln by several cultural treatments after depletion by alfalfa meadows. Cropping to corn, oats, and wheat for 5 years restored only 0.1 inch of moisture to the 6- to 15-foot depth. Continuous corn for 5 years restored 3.1 inches, and continuous fallow restored 13.2 inches of moisture to the 6- to 15-foot level. After 1, 2, 3,4 , and 5 years of continuous fallow, the soil was wet to field capacity to depths of $4,7,8,9$, and 11 feet, respectively. Annual precipitation for this period averaged 1.4 inches below normal.

After depletion of subsoil moisture, there was no material change in deep subsoil moisture during 5 years when alfalfa, sweetclover, and red clover were on the land. These crops were equally ineffective in restoring moisture. Five years of sweetclover or red clover did not deplete deep soil moisture reserves below 6 feet.

\section{Chemical and Physical Effects of Legumes and Grasses on Soils}

In 1929, Russel (\%0) discussed organic-matter problems under dryfarming conditions. After dryland was broken up, there was a gradual disappearance of fiber and degranulation of structure. This produced an increased tendency toward erosion by wind and water. Tillage power requirements were also increased.

He found that dryland crops tended to fire for several years after alfalfa was plowed up. This he attributed to excess nitrate production, which led to rapid growth and premature exhaustion of limited soil moisture. Farm manures were observed to do the same thing. Sweetclover did not cause so serious detrimental effects on subsequent crops as alfalfa.

Russel $(70)$ conducted an experiment at Lincoln to determine the effect of increased organic-matter content on intake and conservation of rainfall. Forty tons per acre of well-rotted manure were incorporated into a clay loam surface soil on a uniform slope of 2 percent. An adjacent plot was used as a check. The two plots were sampled 


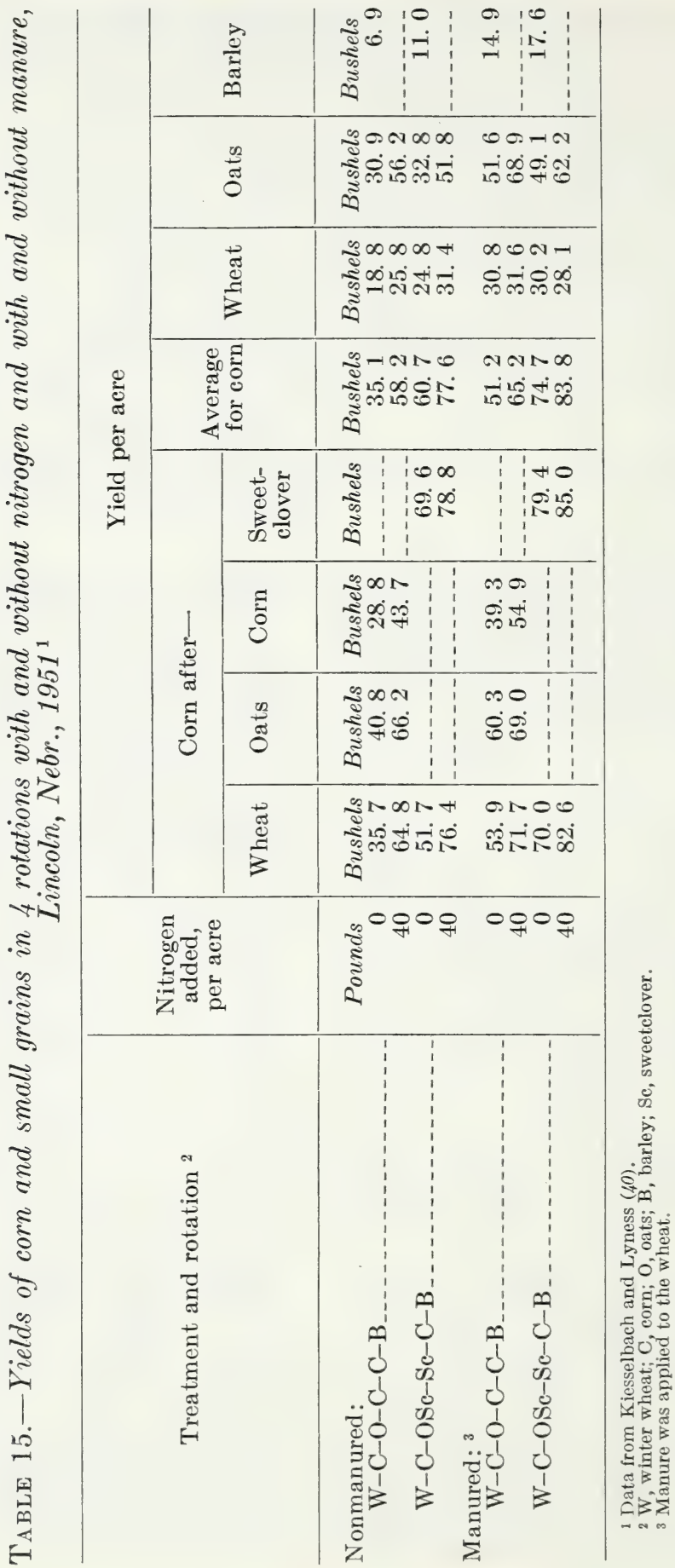


for soil moisture periodically from May 12 to October 14, 1924. Both plots were kept free of vegetation during the period. During the 144-day period, rainfall measured 14.98 inches. On the check plot, 0.94 inches, or 6.3 percent, of the rainfall was conserved. In the manure-treated plot, 2.93 inches, or 19.6 percent, of the rainfall was conserved. Addition of the manure tripled the conservation of rainfall.

Russel (70) found that a high organic-matter content was advantageous in dry weather and detrimental in wet weather. High organic matter was advantageous during dry weather because it reduced soil cracking and lowered evaporation losses. It was detrimental during wet weather because reduced cracking slowed deep water penetration.

Tysdal and Kiesselbach (80) reported that increased soil nitrate production after alfalfa, in eastern Nebraska, was favorable in seasons of high rainfall but was often detrimental when rainfall was deficient. In dry years, nonalfalfa land usually yielded more, because the diminished vegetative growth was better supported by the limited water supply. In eastern Nebraska, the yield increases more than offset the yield depressions. The authors concluded that overstimulation and resultant crop "burning" were more frequent in central and western Nebraska.

In $1946, \mathrm{McHenry}$ and coworkers (47) reported the carbon and nitrogen changes of a Chernozem soil as affected by 1 to 9 years of perennial grass. One of the purposes of this study was to investigate the maintenance of soil organic-matter under various periods of grass. The grass was a mixture of western wheatgrass, crested wheatgrass, and bromegrass. The experiment was conducted at North Platte on Holdrege silt loam.
Their findings show that, with one exception, some loss of nitrogen and carbon occurred, regardless of the number of years in grass (table 16). On plots that had been in grass more than 6 years, total nitrogen and organic-carbon contents were significantly grea ter than the nitrogen and carbon contents of the plots under continuous cultivation.

The authors (47) concluded that perennial grasses do not increase organic-matter levels when included in a cropping system at North Platte. A continuous grass cover barely maintained nitrogen and carbon levels.

McHenry and coworkers (50) studied pore space and aggregation on these same plots. There was no significant difference in pore space saturation related to previous years in grass. Water-stable aggregates were measured in the first cropping year after the grass was plowed. Water-stable aggregates increased in the 1- to 3-inch depth as the number of years in grass increased. In the second cropping year, differences in water-stable aggregates were not related to years in grass. During the first year of cropping, the percentage of water-stable aggregates in 1- to 3-inch depths was correlated with organic matter. Under the conditions of this experiment, any effect that grasses had on measured soil properties was largely dissipated by the end of the first cropping season.

In 1956, the second 10-year cycle of the grass experiments at North Platte was completed. Mazurak and coworkers (54) reported on the effect of age of grass stand and the application of nitrogen on the physical properties of the soil. This was a continuation of the study reported by McHenry and coworkers $(47)$ in 1946 . The main study involved two grasses, intermediate wheatgrass and brome- 
grass; four ages of stand, 2, 4, 6, and 8 years; and two nitrogenfertilizer levels, 0 and 40 pounds of nitrogen per acre. Plots in grass for 20 years and a sequence of grainfallow were used as checks. Maz- urak and coworkers (54) used rate of water entry into the soil to determine the effect of grasses, age of stand, and nitrogen fertilizer on the physical properties of soil (table 17).

TABLE 16.-Changes in total nitrogen and organic-carbon contents of Holdrege silt loam, by soil depths, as influenced by years in perennial grass, North Platte, Nebr., 1935-44 ${ }^{1}$

\begin{tabular}{|c|c|c|c|c|}
\hline \multirow[t]{2}{*}{ Years in sod } & \multicolumn{2}{|c|}{$\begin{array}{l}\text { Gain or loss of total } \\
\text { nitrogen at depth } \\
\text { (inches) of- }\end{array}$} & \multicolumn{2}{|c|}{$\begin{array}{l}\text { Gain or loss of organic } \\
\text { carbon at depth } \\
\text { (inches) of- }\end{array}$} \\
\hline & 0 to 6 & 6 to 12 & 0 to 6 & 6 to 12 \\
\hline (n- & $\begin{array}{l}\text { Percent } \\
-0.003 \\
+.001 \\
-.006 \\
=.009 \\
=.011 \\
-.014 \\
-.019 \\
-.021 \\
-.018 \\
-.016\end{array}$ & $\begin{array}{l}\text { Percent } \\
-0.003 \\
-.009 \\
=.005 \\
-.006 \\
=.016 \\
-.009 \\
=.008 \\
-.008 \\
-.010 \\
-.013\end{array}$ & $\begin{array}{c}\text { Percent } \\
-0.01 \\
-.02 \\
=.02 \\
=.08 \\
=.11 \\
=.12 \\
=.20 \\
=.20 \\
-.17 \\
-.23\end{array}$ & $\begin{array}{r}\text { Percent } \\
-0.00 \\
=.05 \\
=.04 \\
=.06 \\
=.07 \\
=.08 \\
=.11 \\
=.09 \\
=.11 \\
-.11\end{array}$ \\
\hline $\begin{array}{l}\text { Least significant difference at 5- } \\
\text { percent level }\end{array}$ & -0.0137 & & -0.18 & \\
\hline
\end{tabular}

1 Data from McHenry and coworkers (47).

2 Continuously cultivated plots.

TABLE 17.-Average rates, at several interials, of water entry into soil cropped to grain, fallow and to grass for various number of years, North Platte, Nebr., $1956^{1}$

Rotation and age of grass stand (years)

Rate of water entry, per hour, at end of-

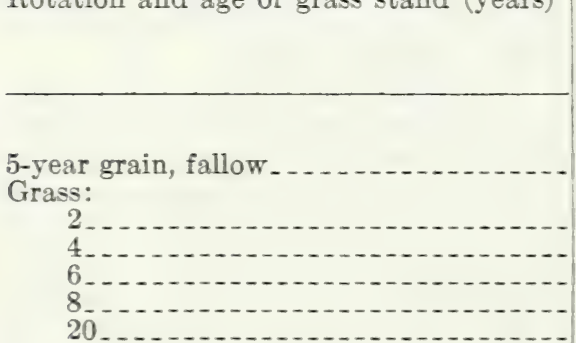

\begin{tabular}{|c|c|c|c|c|c|}
\hline $\begin{array}{c}5 \\
\min .\end{array}$ & $\begin{array}{c}10 \\
\text { min. }\end{array}$ & $\begin{array}{c}20 \\
\text { min. }\end{array}$ & $\begin{array}{c}60 \\
\text { min. }\end{array}$ & $\begin{array}{l}120 \\
\text { min. }\end{array}$ & $\begin{array}{l}360 \\
\text { min. }\end{array}$ \\
\hline $\begin{array}{c}\mathrm{Cm} . \\
8.4\end{array}$ & $\begin{array}{l}\mathrm{Cm} . \\
3.7\end{array}$ & $\begin{array}{c}\mathrm{Cm} . \\
2.2\end{array}$ & $\begin{array}{l}\mathrm{Cm} . \\
1.2\end{array}$ & $\begin{array}{l}\mathrm{Cm} . \\
1.05\end{array}$ & $\begin{array}{c}\mathrm{Cm} . \\
0.95\end{array}$ \\
\hline 9. 3 & 5.9 & 3.9 & 2.0 & 1. 8 & 1. 6 \\
\hline $\begin{array}{r}10.0 \\
\end{array}$ & 6. 6 & 4.8 & 3.0 & 2. 8 & 2. 8 \\
\hline 8. 4 & 6. 0 & 4. 0 & 2. 5 & 2. 6 & 2. 1 \\
\hline 8. 0 & 5. 2 & 3.9 & 3. 0 & 3. 2 & 3.4 \\
\hline 10. 8 & 7. 3 & 5. 1 & 4. 6 & 4. 8 & 4. 9 \\
\hline & & 0.4 & 0. 3 & 0.3 & 0. 3 \\
\hline
\end{tabular}

'Data from Mazurak and coworkers (54). 
Only age of grass showed any statistical significance in rate of water entry (table 17). Rate of water entry for each time interval beyond 10 minutes generally increased with increased age of grass. Four years of grass substantially improved soil structure. Twentyyear grass plots showed the highest rate of water entry at all time intervals. Bulk density of the surface 3 inches of soil was significantly decreased by 6- to 20-year grass stands.

Their data (table 18) indicate that the total nitrogen and oxidizable organic matter in the surface 6 inches increased with the age of grass stand. Nitrogen fertilizer increased the nitrogen content of the surface soil, but it had no significant influence on the organic matter.

Mazurak and Conard (53) compared rates of water entry into soils of three Great Soil Groups when cropped for 7 years to various grasses and small grains. Only the data for the Chernozem and the Chestnut soils are presented (tables 19 and 20). The Chernozem was Holdrege fine sandy loam near North Platte. The Chestnut was Rosebud very fine sandy loam near Alliance. On the Chernozem soil, five cool-season grasses, four warmseason grasses, and a wheat, fallow rotation were compared. Only coolseason grasses and a wheat, fallow rotation were compared on the Chestnut soil. Half of each plot was fertilized with nitrogen each spring. In both studies, moisture content of the soils were near the permanent wilting percentage when rates of water entry were measured.

On both soils, the rate of water entry for the first 10 minutes was highest for the wheat, fallow rotation plots. Infiltration rate was determined when the land was in stubble. On the Chernozem soil,

TABLE 18.-Total nitrogen and oxidizable organic-matter contents of soil by soil depths, as influenced by the age of grass and application of nitrogenous fertilizer, North Platte, Nebr., 1947-56 ${ }^{1}$

\begin{tabular}{|c|c|c|c|c|c|}
\hline \multirow{2}{*}{$\begin{array}{l}\text { Rotation and age of } \\
\text { grass (years) } \\
\text { (1) }\end{array}$} & \multirow{2}{*}{$\begin{array}{l}\text { Annual ap- } \\
\text { plication of } \\
\text { nitrogenous } \\
\text { fertilizer, } \\
\text { per acre } \\
\text { (2) }\end{array}$} & \multicolumn{2}{|c|}{$\begin{array}{l}\text { Total nitrogen at } \\
\text { depth (inches) of }{ }^{2}-\end{array}$} & \multicolumn{2}{|c|}{$\begin{array}{l}\text { Total oxidizable } \\
\text { organic matter at } \\
\text { depth (inches) of }{ }^{2}-\end{array}$} \\
\hline & & $\begin{array}{l}0 \text { to } 6 \\
(3)\end{array}$ & $\begin{array}{c}6 \text { to } 12 \\
(4)\end{array}$ & $\begin{array}{l}0 \text { to } 6 \\
(5)\end{array}$ & $\begin{array}{c}6 \text { to } 12 \\
(6)\end{array}$ \\
\hline $\begin{array}{l}\text { 5-year grain fallow } \\
\text { Grass: }\end{array}$ & $\begin{array}{r}\text { Pounds } \\
0 \\
\\
40 \\
0 \\
40 \\
0 \\
40 \\
0 \\
40 \\
0 \\
0\end{array}$ & $\begin{array}{r}\text { Percent } \\
0.092 \\
\\
.097 \\
.096 \\
.105 \\
.100 \\
.109 \\
.104 \\
.122 \\
.109 \\
.121\end{array}$ & $\begin{array}{r}\text { Percent } \\
0.088 \\
\\
.103 \\
.098 \\
.102 \\
.098 \\
.107 \\
.106 \\
.106 \\
.104 \\
.102\end{array}$ & $\begin{array}{r}\text { Percent } \\
1.6 \\
1.8 \\
1.9 \\
2.1 \\
1.9 \\
2.2 \\
2.1 \\
2.4 \\
2.2 \\
2.7\end{array}$ & $\begin{array}{r}\text { Percent } \\
1.6 \\
1.8 \\
1.8 \\
1.9 \\
1.9 \\
2.0 \\
2.0 \\
2.2 \\
2.0 \\
2.0\end{array}$ \\
\hline
\end{tabular}

1 Data from Mazurak and coworkers (54).

2 Differences statistically significant (at the 5-percent level) for comparisons between ages and between fertilizer and no fertilizer in column 3 and between ages in column 5 . 
TABLE 19.-Rates, at several intervals, of water entry into a Chernozem soil after 7 years of grasses and wheat, fallow, North Platte, Nebr., August $1954^{1}$

\begin{tabular}{|c|c|c|c|c|c|c|}
\hline \multirow{2}{*}{ Species or rotation } & \multicolumn{6}{|c|}{ Rate of water entry, per hour, at end of- } \\
\hline & $\begin{array}{c}5 \\
\min \end{array}$ & 10 & $\begin{array}{l}20 \\
\min \end{array}$ & $\begin{array}{c}60 \\
\text { min. }\end{array}$ & $\begin{array}{l}120 \\
\min .\end{array}$ & $\begin{array}{l}420 \\
\min \end{array}$ \\
\hline \multirow{7}{*}{$\begin{array}{l}\text { Cool-season grasses: } \\
\text { Agropyron smithii (western wheat- } \\
\text { grass) } \\
\text { Elymus junceus (Russian wildrye) } \\
\text { Agropyron intermedium (intermedi- } \\
\text { ate wheatgrass) } \\
\text { Agropyron desertorum (desert wheat- } \\
\text { grass) } \\
\text { Bromus inermis (smooth bromegrass) }\end{array}$} & & & $\mathrm{Cm}$ & $\mathrm{Cm}$. & $\mathrm{Cm}$. & $\mathrm{Cm}$ \\
\hline & 7. 4 & 6. 2 & 5. 2 & 4. 8 & 4. 9 & 5. 4 \\
\hline & 6.8 & 6. 1 & 5.5 & 5. 0 & 5. 1 & 5. 9 \\
\hline & 7. 1 & 5. 9 & 5. 2 & 4. 6 & 4. 7 & 5. 2 \\
\hline & 5. 0 & 4. & 3. 8 & 4. 0 & 4. 4 & 5. 5 \\
\hline & 4. 4 & 3.3 & 2. 8 & 2. & & 4. 1 \\
\hline & 6. 1 & 5. 1 & 4. 5 & 4. 2 & 4. 4 & 5. 2 \\
\hline \multirow{4}{*}{$\begin{array}{l}\text { Warm-season grasses: } \\
\text { Andropogon gerardi (big bluestem) } \\
\text { Bouteloua gracilis (blue grama) } \\
\text { Buchloe dactyloides (buffalograss) } \\
\text { Bouteloua curtipendula (side-oats } \\
\text { grama) }\end{array}$} & & & & & & \\
\hline & 7.9 & $\begin{array}{l}\text { 0. } 9 \\
6.9\end{array}$ & $\begin{array}{l}0.3 \\
5.7\end{array}$ & 4. 7 & 5. 8 & $\begin{array}{l}\text { 5. } 9 \\
\text { 4. } 9\end{array}$ \\
\hline & 4. 6 & 3.3 & 2. 9 & 2. 4 & 2. 2 & 2. 1 \\
\hline & 8. 0 & 6. 3 & 5. 3 & 4. 7 & 4. 6 & 4. 9 \\
\hline \multirow{2}{*}{ Mean } & 7. 1 & 5.8 & 5. 0 & 4. 4 & 4. 3 & 4. 4 \\
\hline & 9.4 & 7. 9 & 6. 4 & 4. 0 & 3. 2 & 3.1 \\
\hline $\begin{array}{l}\text { Least significant difference ( } 5 \text {-per- } \\
\text { cent level) between means. }\end{array}$ & 2. 0 & 1. 6 & 1. 6 & 1. 7 & 1. 8 & 2. 0 \\
\hline
\end{tabular}

1 Data from Mazurak and Conard (53)

the highest rates of water entry after 10 minutes for the plots cropped to cool-season grasses were the plots cropped to Agropyron smithii, Elymus junceus, and A. intermedium. All plots cropped to the warm-season grasses except that to Buchloe dactyloides had high rates of water entry at the end of 10 minutes. After 7 hours, all the plots cropped to grasses except that to $B$. dactyloides had higher rates of water entry than the wheat, fallow rotation plot.' The plot cropped to $B$. dactyloides had significantly lower infiltration rates for the entire study period than any of the other grass plots. On the Chestnut soil, the plot cropped to $A$. smithii had distinctly higher rates of water entry than the plots cropped to other grasses or to grain at the end of 120 and 420 minutes.

Nitrogen fertilizer did not significantly alter the rates of water entry into the two soils.

McHenry and Newell (48) investigated the effects of perennial grasses on total nitrogen, organic matter, and soil structure. The grasses were grown on Butler silty clay loam (Planosol) at Lincoln, from 1938 to 1945 . Total nitrogen and readily oxidizable organic-matter content of the soil increased significantly under various grass covers for the 0 - to 6 -inch depth. The seasonal growth habits of the various grasses showed no distinct differences in total nitrogen and 
TABLE 20.-Rates, at several intervals, of water entry into a Chestnut soil after 7 years of grasses and wheat, fallow, Alliance, Nebr., August $1952^{1}$

\begin{tabular}{|c|c|c|c|c|c|c|c|}
\hline \multirow{2}{*}{ Species or rotation } & \multicolumn{7}{|c|}{ Rate of water entry, per hour, at end of- } \\
\hline & $\begin{array}{c}\tilde{5} \\
\min \end{array}$ & $\begin{array}{c}10 \\
\min \end{array}$ & $\begin{array}{c}20 \\
\min \end{array}$ & $\begin{array}{l}40 \\
\text { min. }\end{array}$ & $\begin{array}{l}60 \\
\min \end{array}$ & $\begin{array}{l}120 \\
\min \end{array}$ & $\begin{array}{l}420 \\
\min \end{array}$ \\
\hline $\begin{array}{l}\text { Cool-season grasses: } \\
\text { Agropyron smithii (western }\end{array}$ & $\mathrm{Cm}$. & $\mathrm{Cm}$ & $\mathrm{Cm}$. & $\mathrm{Cm}$ & $\mathrm{Cm}$ & $\mathrm{Cm}$ & $C m$ \\
\hline wheatgrass) & 10. 2 & 8.4 & 7. 7 & 7. 2 & 6. 9 & 6.4 & 6. 1 \\
\hline $\begin{array}{l}\text { Agropyron desertorum (desert } \\
\text { wheatgrass) }\end{array}$ & 11.5 & 8. 4 & 6.3 & 5. 0 & 4. 7 & 4. 4 & 4. 7 \\
\hline $\begin{array}{l}\text { Agropyron cristatum (crested } \\
\text { wheatgrass) }\end{array}$ & 11. 6 & 8.2 & 6. & 5. 4 & 4. 1 & 3.3 & 2. 8 \\
\hline $\begin{array}{l}\text { Elymus junceus (Russian } \\
\text { wildrye) }\end{array}$ & 8.5 & 7. 1 & 5. 6 & 4. 1 & 3.4 & 2. 6 & 2. 3 \\
\hline $\begin{array}{l}\text { Agropyron intermedium (in- } \\
\text { termediate wheatgrass) }\end{array}$ & 9.6 & 6.3 & 4. 7 & 3. 4 & 2. 9 & 2.5 & 2.4 \\
\hline $\begin{array}{l}\text { Bromus inermis (smooth } \\
\text { brome) }\end{array}$ & 7. 2 & 5.8 & 4. 8 & 4. 0 & 3.8 & 3.5 & 36 \\
\hline Mean_... & 9.8 & 7.4 & 5. 9 & 4. 8 & 4. 3 & 3. 8 & 5. 6 \\
\hline Wheat, fallow..- & 14. 1 & 10.8 & 7. 7 & 5.4 & 4. 4 & 3.3 & 2.4 \\
\hline $\begin{array}{l}\text { Least significant difference } \\
\text { (5-percent level) between } \\
\text { means.- }\end{array}$ & 4. 4 & 2. 6 & 2. 1 & 2. 3 & 2.5 & 2. 7 & 3. 0 \\
\hline
\end{tabular}

1 Data from Mazurak and Conard (53).

readily oxidizable materials. Blue grama, buffalograss, bromegrass, bluegrass, and orchardgrass produced the highest organic-matter contents. Side-oats grama, blue grama, bluegrass, and bromegrass imparted the greatest stability to soil aggregates as measured by the percentage of soil aggregates greater than $0.25 \mathrm{~mm}$. diameter. No significant difference was found for measurements of pore-space saturation, or volume weight.

Their findings indicate that organic-matter content was higher and physical condition of the soil cropped to grass was better than that in an adjoining cultivated field. Stable soil aggregates were correlated with total nitrogen content and readily oxidizable material, but they were not closely related to the vegetative production of the various grasses. Differences in ag- gregate stability were attributed to differential root development of the grasses.

After 2 years of small-grain cropping, McHenry and Newell (49) again determined the water-stable aggregates in the soil from the same plots as sampled in their previous study. Water-stable aggregates greater than $0.25 \mathrm{~mm}$. had decreased an average of 70 percent in all grass plots except buffalograss plots. Buffalograss plots decreased approximately 50 percent in aggregate stability.

Duley and Domingo (18) made infiltration tests on several grassland soils to determine the effect of grass cover on infiltration. A sprinklertype infiltrometer was used. The total cover, including live grass and associated litter, affected infiltration more than the kind of grass or the type of soil. There was little 
indication that grass roots had much effect on water intake.

Duley and Russel (19) investigated the use of sweetclover in stubble-mulch farming. Along the border of the Great Plains and the Corn Belt, two objections to the use of sweetclover as a soil-improvement crop have been made by farmers. First, it was considered a moisture-depleting crop that affected the growth of the following crop, and secondly, it was believed that sweetclover made the land more erodible. The data (table 21) indicate that subtilling the sweetclover crop rather than plowing for green manure was an effective way of handling the crop.

The data illustrate the effectiveness of surface sweetclover residue in reducing runoff and erosion as compared with the residue plowed under. Crop yields after subtilling and plowing the sweetclover were essentially the same.

McCalla and Russel (46) studied production of soil nitrates as af- fected by sweetclover residues left on the soil surface. Available nitrogen with first-year corn after 2 years of sweetclover was 10 percent lower in subtilled plots than in plowed plots. The amount of available nitrogen produced was believed to be sufficient to produce large yields of corn and other crops. The authors suggested that lowered nitrate production would reduce overstimulation under limited moisture conditions. No data were presented to support this belief, however.

Duley and coworkers (20) reported on soil conservation and management on sandy farmland in northeastern Nebraska. On the sandy soils east of the Sand Hills section, much of the land is cultivated. These soils are subject to severe blowing and are relatively low in productivity. Sloping land soils are exposed to severe water erosion. In 1950, the Research Department of the U.S. Soil Conservation Service and the Agronomy

TABLE 21.-Effects of subtilling and plowing sweetclover on runoff and erosion, Lincoln, Nebr., 1942, 1946, $1947^{1}$

\begin{tabular}{|c|c|c|c|c|c|}
\hline \multirow{2}{*}{ Date } & \multirow{2}{*}{ Crop and residue } & \multicolumn{2}{|c|}{ Runoff } & \multicolumn{2}{|c|}{ Erosion } \\
\hline & & Subtilled ${ }^{2}$ & Plowed & Subtilled ${ }^{2}$ & Plowed \\
\hline $1942 \ldots$ & Second-year corn after & $\begin{array}{l}\text { Inches } \\
\quad 1.05\end{array}$ & $\begin{array}{r}\text { Inches } \\
1.93\end{array}$ & $\begin{array}{l}\text { Tons per } \\
\text { acre } \\
\text { 3. } 64\end{array}$ & $\begin{array}{c}\text { Tons per } \\
\text { acre } \\
7.36\end{array}$ \\
\hline $1942 \ldots$ & First-year corn after & .58 & 1. 84 & 1. 43 & 13. 33 \\
\hline 1946 & Corn after 2 years of & $\mathrm{T}$ & .36 & $\mathrm{~T}$ & 1. 49 \\
\hline 1946. & Corn after 1 year of & $\mathrm{T}$ & .04 & $\mathrm{~T}$ & .03 \\
\hline 1947. & $\begin{array}{l}\text { Oats after } 2 \text { years of } \\
\text { sweetclover. }\end{array}$ & .45 & 1. 76 & .17 & .21 \\
\hline Totals . . . . & n-n & 2. 08 & 5. 93 & 5. 24 & 22. 42 \\
\hline $\begin{array}{l}\text { Relative } \\
\text { amounts. }\end{array}$ & -1 & & 2. 85 & & 4. 28 \\
\hline
\end{tabular}

1 Data from Duley and Russel (19).

$2 \mathrm{~T}$, trace. 
Department of the Nebraska Agricultural Experiment Station began cooperative studies on the Pierce Soil Conservation District farm in Pierce County. Chief soil conservation problems were: (a) preventing wind and water erosion and (b) increasing crop yields through improved soil fertility.

They reported that wind and water erosion were controlled effectively by (a) keeping the land covered with a vigorous-growing crop as much of the time as possible and (b) keeping the residue from the previous crop on the surface to prevent soil movement by wind when there was no crop growing on the land. Large yields of residue were necessary to protect the soil in the interval between crops.

They found that supplemental nitrogen was necessary to improve grain and forage yields. Their initial effort to supply more nitrogen was by growing more legumes. Their tests proved that vetch and partridgepea can be grown on these sandy soils without special soil treatment but that lime and phosphate improved their growth and effect on succeeding crops. Sweetclover, lespedeza, and alfalfa were grown successfully where the soil has been limed and phosphated (table 22).
Vetch and biennial sweetclover were considerably more effective in increasing corn yields than the other three legumes. Inorganic nitrogen also produced profitable yield responses when applied to nonlegume grains and grasses.

Comprrisons between legume and commercial nitrogen were limited to rye in 1952 . Vetch was more effective in increasing rye grain yields than was 33 pounds of ammonium nitrate. Partridgepea was about equal to 33 pounds of ammonium nitrate. Unfortunately, other rates of nitrogen were not used.

Duley (16) reported on yields in different cropping systems and fertilizer treatments under stubble mulching and plowing in eastern Nebraska. Soil type was Sharpsburg silty clay loam, rolling phase, at the University of Nebraska. He gave yields from legume and nonlegume rotations during years of varying moisture supplies (table 23).

His data (table 23) indicate that in certain years higher yields were obtained from the nonlegume rotations than from rotations including sweetclover. These were usually the years of extreme moisture conditions, either too wet or too dry.

Duley (16) conducted a separate fertilizer experiment with corn on subtilled land for 3 years (table 24).

TABLE 22.-Average yields of corn in legume and nonlegume rotations and the increase from the legume, Sandy Land Farm, Pierce, Nebr., 1951-52 12

\begin{tabular}{|c|c|c|}
\hline Previous-year crop & $\begin{array}{l}\text { 2-year mean } \\
\text { corn yield, } \\
\text { per acre }\end{array}$ & $\begin{array}{l}\text { Increase, per } \\
\text { acre, over } \\
\text { no legumes }\end{array}$ \\
\hline $\begin{array}{l}\text { Vetch } \\
\text { Biennial sweetclover } \\
\text { Annual sweetclover } \\
\text { Lespedeza } \\
\text { Partridgepea } \\
\text { No legumes }\end{array}$ & $\begin{array}{r}\text { Bushels } \\
59.6 \\
56.6 \\
47.2 \\
35.8 \\
32.4 \\
27.0\end{array}$ & $\begin{array}{r}\text { Bushels } \\
32.6 \\
29.6 \\
20.2 \\
8.8 \\
5.4\end{array}$ \\
\hline
\end{tabular}

1 Data from Duley and coworkers (20).

21 ton of lime per acre was applied in $1950 ; 86$ pounds $\mathrm{P}_{2} \mathrm{O}_{5}$ per acre at legume seeding in 1950 and 1951. 711-108-64-5 
His data (tables 23 and 24) indicate that nitrogenous fertilizer was more effective than sweetclover in increasing corn yields in 1953 and 1955. The optimum rate of nitrogenous fertilizer varied with yield level and rainfall.

\section{Summary}

Rye and pea green-manure fallow reduced yields of winter wheat, spring wheat, and oats below those for ordinary fallow at Scottsbluff and North Platte. At North Platte, in favorable years green manures plowed down 3 years previously had some beneficial effect. In unfavorable years, pea green manure plowed down 3 years previously reduced wheat yields. Four years of weeds, bromegrass, and sweetclover had no differential effect on succeeding yields of wheat and corn.

$\mathrm{T}_{\mathrm{ABLE}}$ 23.- Yields of corn in legume and nonlegume rotations during years of varying rainfall, Lincoln, Nebr., 1947-56 ${ }^{1}$

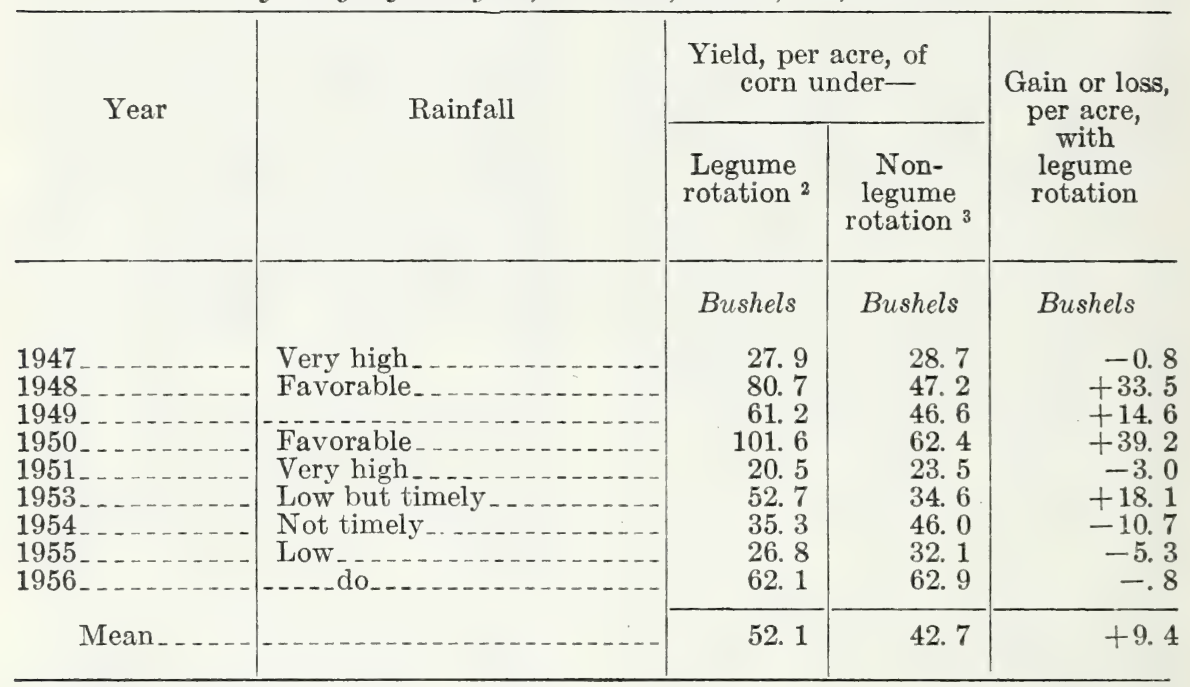

1 Data from Duley (16).

2 Sweetclover, sweetclover, wheat, corn, oats.

3 Corn, oats, wheat.

TABLE 24.-Yields of corn with no nitrogenous fertilizer and with 40 and 80 pounds per acre, on subtilled land, Lincoln, Nebr., 1953-55 ${ }^{1}$

\begin{tabular}{|c|c|c|c|c|}
\hline \multirow[t]{2}{*}{ Year } & \multirow[t]{2}{*}{ Rainfall } & \multicolumn{3}{|c|}{$\begin{array}{c}\text { Grain yield, per acre, with } \\
\text { indicated pounds of nitrogen } \\
\text { (per acre) }\end{array}$} \\
\hline & & 0 & 40 & 80 \\
\hline $\begin{array}{l}1953 \ldots \\
1954 \ldots \\
1955 \ldots\end{array}$ & $\begin{array}{l}\text { Low but timely } \\
\text { Not timely } \\
\text { Low }\end{array}$ & $\begin{array}{r}\text { Bushels } \\
48.2 \\
45.1 \\
31.2\end{array}$ & $\begin{array}{r}\text { Bushels } \\
51.4 \\
44.7 \\
39.0\end{array}$ & $\begin{array}{l}\text { Bushels } \\
61.0 \\
48.3 \\
31.1\end{array}$ \\
\hline
\end{tabular}

1 Data from Duley (16). 
Legumes and grasses are well suited to the cropping systems for sandy farm lands of northeastern Nebraska. Soil conservation problems in this section consist chiefly of (1) preventing wind and water erosion and (2) increasing crop yields through improved soil fertility. Legumes and grasses provide maximum protection from wind erosion. Lime and phosphate are required on most land for sweetclover, lespedeza, and alfalfa. Fertilizer nitrogen may be needed to supplement the legume nitrogen on most farms.

At Lincoln, alfalfa used soil moisture to a depth of 33 feet. Deep subsoil moisture reserves were not replenished during subsequent cropping to small grains. Continuous corn restored some of the subsoil moisture. Five years of continuous fallow restored subsoil moisture to field capacity to only 11 feet. Storage efficiency was extremely low.

At Lincoln, sweetclover and red clover did not deplete soil moisture reserves below 6 feet during 192832.

Crop-rotation experiments at Lincoln showed that alfalfa, red clover, and sweetclover were effective in increasing yields of corn and small grain. Limited data showed that sweetclover, in a 6-year rotation without lime, did not supply adequate nitrogen for the rotation. These data indicate that nitrogen fertilizer may be used in place of or at least to supplement legume nitrogen to maintain and increase grain yields.

Perennial grasses increased nitrogen and organic-matter contents of the soil after 6 to 10 years at both North Platte and Lincoln. At North Platte, the rate of water entry into soil increased with age of grass.

At Lincoln, side-oats grama, blue grama, bluegrass, and bromegrass imparted the greatest stability to soil aggregates, as measured by the precentage of aggregates greater than $0.25 \mathrm{~mm}$. diameter. Two years after the grass plots were plowed and cropped, water-stable aggregates in all grass plots except buffalograss plots had decreased 70 percent. Buffalograss plots showed approximately 50 percent decrease in aggregation.

\section{Kansas}

\section{Yields}

Green-manure experiments were started at Hays, Kans., in $1908^{7}$ and Colby, Kans., in 1915 (44). Yields of several crops after greenmanure fallow, continuous cropping, and ordinary fallow are presented (table 25).

In 1945 , Hallsted ${ }^{7}$ tabulated the yields from the dryland experiments at Hays. Annual precipitation averaged 22.7 inches.

His data indicate that yields of winter wheat and barley after green-manure fallow were less than after ordinary fallow. Yields after rye or pea green-manure fallow were greater than with continuous cropping.

Kuska and Mathews (44) reported the results of experiments with crop rotations at Colby for 1915-50. Annual precipitation averaged 18.5 inches. Their data on yields of milo and winter wheat in green-manure and comparable rotations for 1915-47 are presented (table 26).

Their findings show that yields of milo immediately after greenmanure fallow were lower than those after ordinary fallow (table 26). They concluded that this was because of moisture used in producing

7 Hallsted, A. L. TABUlated yield FROM DRYLAND AGRICULTURE TILLAGE AND ROTATION EXPERIMENTS CONDUCTED AT HAYs, Kansas. Kans. Agr. Expt. Sta. [Unpublished Rpt.]. 1945. 
34 Miscellaneous PUblication 952, U.S. DEPT. OF AGRICUlture

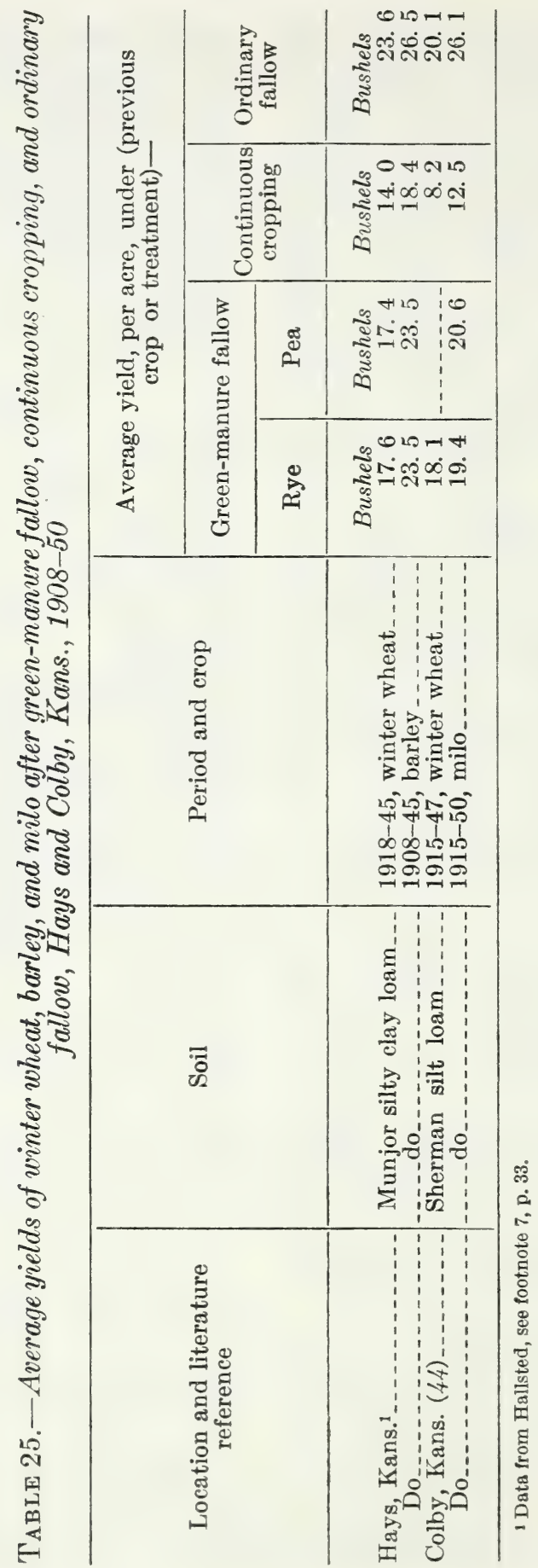


TABLE 26.-Average yields of milo and winter wheat in various rotations, Colby, Kans., 1915-47 1

\begin{tabular}{|c|c|c|c|c|}
\hline \multirow{3}{*}{ Rotation } & \multicolumn{4}{|c|}{ Average yield, per acre, of- } \\
\hline & \multicolumn{2}{|c|}{ Milo } & \multicolumn{2}{|c|}{ Winter wheat ${ }^{2}$} \\
\hline & Grain & Stover & Grain & Straw \\
\hline $\begin{array}{l}\text { Rye, }{ }^{3} \text { milo, fallow, winter wheat } \\
\text { Field peas, }{ }^{3} \text { milo, fallow, winter wheat } \\
\text { Fallow, milo, fallow, winter wheat } \\
\text { Fallow, crop, } \\
\text { Continuous crop }\end{array}$ & $\begin{array}{c}\text { Bushels } \\
20.3 \\
20.6 \\
25.4 \\
24.9 \\
12.0\end{array}$ & $\begin{array}{r}\text { Pounds } \\
3,330 \\
3,310 \\
3,860 \\
\end{array}$ & $\begin{array}{r}\text { Bushels } \\
20.5 \\
19.6 \\
18.9 \\
18.8 \\
7.3\end{array}$ & $\begin{array}{r}\text { Pounds } \\
2,410 \\
2,280 \\
2,760 \\
\end{array}$ \\
\hline
\end{tabular}

1 Data from Kuska and Mathews (44).

23 years after green manure.

8 Green-manure fallow.

the green-manure crop. The third year after green-manure fallow, winter wheat on fallow produced slightly more grain, but less straw, than in a similar non-green-manure rotation.

Fallow was substituted for the green-manure crop in the same rotations for 1948-50 (44). During this period grain yields of both milo and wheat in the green-manure rotations were almost exactly equal to those in the fallowed rotations.

The authors concluded that there were no apparent differences between the effects of winter rye and field peas as green-manure crops and that there were no cumulative beneficial effects from their use.

The average yields of most crops for the last 5 years of the experiments compared favorably with the average for the second 5 years, when the precipitation was essentially the same (44). On some plots, the highest yields were obtained in 1947, after 34 years of cropping to the same crop. This indicated soil productivity had not declined appreciably with time.

Metzger (55) studied residual effects of several alfalfa cropping periods on yield and protein con- tent of succeeding wheat crops at Manhattan, Kans. Alfalfa cropping for 2 years increased the protein content of wheat for at least 8 years. Yield increases persisted for about 3 years. Longer periods of alfalfa cropping produced greater residual effects, but footrot disease problems made it impossible to obtain reliable data on longtime effects.

In 1955, Hobbs (32) reported the effect of different crop rotations on crop yields at Manhattan. On unfertilized plots, wheat yields declined with time except in the alfalfa rotation. Corn yields were maintained or increased with the alfalfa rotation by all fertilizer and manure treatments. In the nonalfalfa and continuous cropping systems, corn yields declined regardless of fertilizer or manure treatments.

Alfalfa-yield trends were downward. Hobbs believed that moisture had become the main limiting factor in the second and subsequent times that this crop was seeded on a plot of land. Another possible explanation, not mentioned, is that the nutrient supply in the deep 
subsoil may have been depleted to the extent that it limited production.

The regression lines calculated from annual vields of treated and untreated wheat, corn, and alfalfa when grown continuously on the same land are shown in figure 2.

\section{Legumes Versus Inorganic Nitrogen Sources}

Bray and Schnittker (4) studied the economics of crop rotations in eastern and central Kansas. Part of their studies were based on Hobbs' data (32). If prices for alfalfa hay are favorable, they concluded that up to 25 percent of the cropland in eastern Kansas could profitably be cropped to alfalfa. However. the data showed that fertilizers were good substitutes for legumes in rotation unless there were soil structure or erosion problems.

\section{Soil Moisture Use by Legumes and Grasses}

In 1929, Duley (15) reported the effect of alfalfa on soil moisture at Manhattan on Geary silt loam. Alfalfa reduced the moisture content of the deep subsoil to a low level, which then remained constant as long as alfalfa was on the land. When alfalfa land in a 16vear rotation was broken and planted to corn and wheat for 10 years, the deep subsoil failed to gain significant moisture. Similar results were obtained in Nebraska (39).

In 1936, Grandfield and Metzger (23) found that alfalfa depleted the available moisture to a depth of 25 feet in 2 years at Manhattan. Clean fallow restored moisture in 2 vears. These results are at variance with Nebraska results (39), where 5 years of fallow failed to restore moisture below the 11-foot level. The difference in rate of restoration of subsoil moisture un- der fallow in the Kansas and Nebraska experiments emphasizes the importance of soil and climatic variability. Apparently the soil at Manhattan was more permeable than the soil at Lincoln. Annual precipitation areraged 31.9 inches at Manhattan and 27.5 inches at Lincoln.

In 1953, Hobbs (31) reported on replenishment of soil moisture supplies after the growth of alfalfa and bromegrass at Manhattan for 1938-49. The land was plowed out of alfalfa and bromegrass in 1937 and cropped to cereals for 12 years. Twelve years of cereal cropping resulted in water being stored to a depth of at least 22 feet. This deep moisture reserve was arailable to alfalfa but not to cereals. If not used by deep-rooted crops such as legumes, this water would eventually move to the water table. Annual precipitation for the 12 years areraged 0.62 inch above normal. From October 1941 to October 1945 annual precipitation exceeded longtime averages by 13.4 , $1.3,11.3$, and 10.6 inches. Moisture samplis were not taken during this period, but it seems probable that most of the deep moisture storage may have occurred in this 4-year period.

The disagreement between Hobbs' (31) and Duley's (15) data are believed to be due to exceptionally wet years that occurred during Hobbs' study. Hobbs found that bromegrass did not seriously deplete soil moisture below 4 feet.

Under favorable rainfall conditions, Hobbs concluded that it was unnecessary to rallow for planting alfalfa on land previously sown to this crop, provided a sufficient number of cereal crops had been produced between alfalfa crops.

Myers (58) found that sweetclover grown for two seasons reduced the subsoil moisture to a maximum depth of 14 feet at Man- 


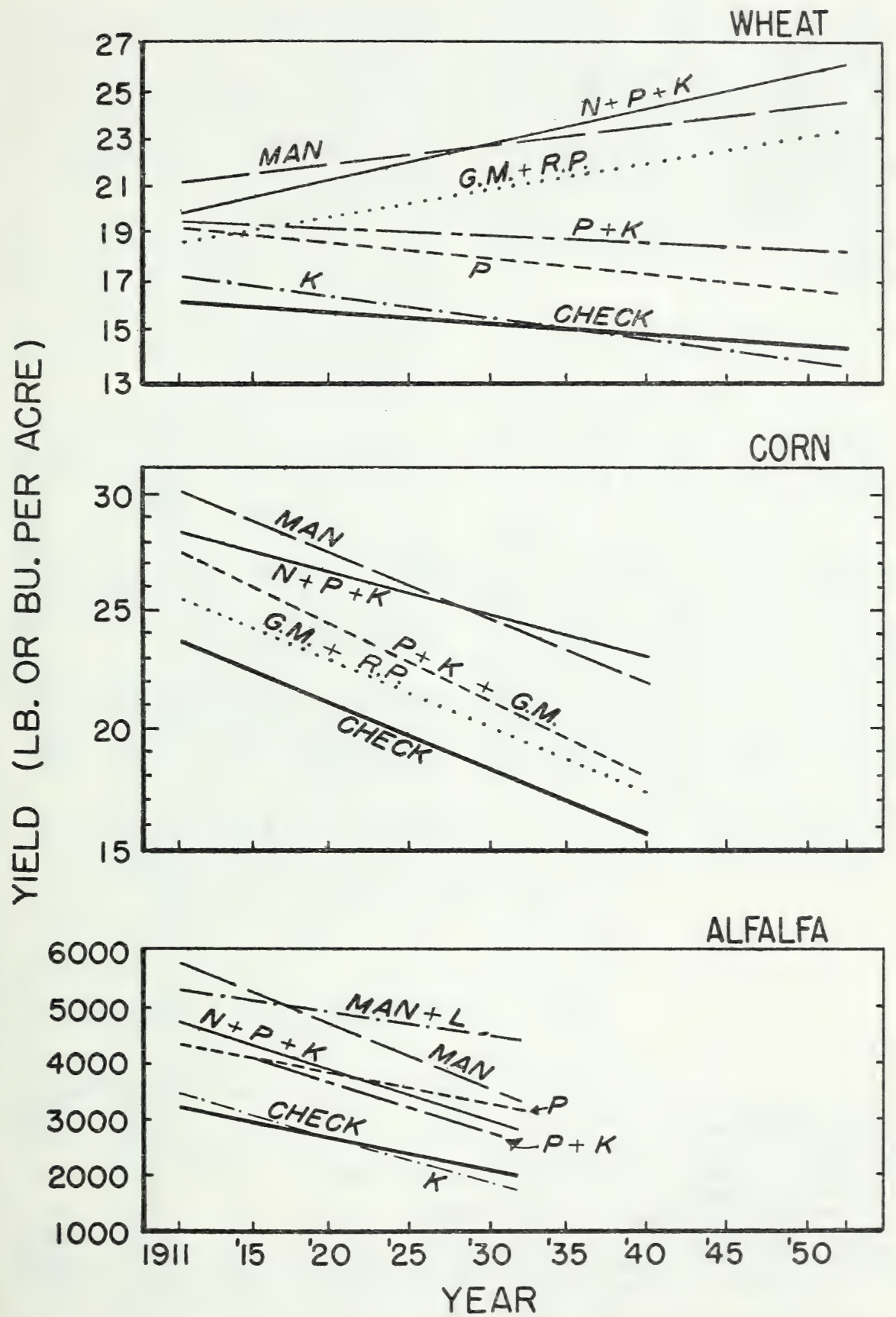

FIGURE 2.-Regression lines calculated from the annual yields of treated and untreated wheat, corn, and alfalfa when grown continuously on the same land at Manhattan, Kans. From Hobbs (32). 
hattan. One year's growth of sweetclover reduced the subsoil moisture to near the wilting point to a maximum depth of 9 feet. The growth of sweetclover for 1 or 2 years under limited rainfall conditions may result in the development of a dry layer of sufficient depth to prevent utilization of moisture at a lower leve] by subsequent alfalfa crops.

\section{Chemical and Physical Effects of Legumes and Grasses on Soils}

Nitrogen and carbon changes of the soils have been measured periodically at the Hays, Colby, and Garden City Branch Experiment Stations $(34,35,59)$.

In 1943, Myers and coworkers (59) reported on nitrogen and carbon changes in the 0 - to 7 -inch layer of these soils during 1916-38. The higher the nitrogen and carbon contents of the soil in 1916, the greater the loss of these elements during this period. Cropping system showed a definite relationship to the loss of each element. Continuous small-grain production and alternate small grain and fallow caused relatively low losses. Continuous row crops and alternate row crops and fallow produced the greatest losses. Rotations including row crops and small grain produced intermediate losses.

In 1957, Hobbs and Brown (34, $35)$ reported on nitrogen and organic-carbon changes for 1916-46. Nitrogen losses are curvilinear with time; the greatest losses occurring in the years immediately after sod breaking (fig. 3 ).

Although a new nitrogen equilibrium at each station was indicated, apparently no location had reached that equilibrium. Figure 3 indicates that highest equilibrium will be reached in the soils with the highest original nitrogen content (Hays) and the lowest equilibrium in the soils with the lowest original content (Garden City).

Hobbs and Brown found that green manure had differential effects on nitrogen and carbon losses from the surface soils at Hays, Colby, and Garden City (table 27).

TABLE 27.-Losses of nitrogen and carbon from 0- to 6-inch soil depths with various rotations at Hays, Colby, and Garden City, Kans., 1916-46 ${ }^{1}$

\begin{tabular}{|c|c|c|c|c|c|c|}
\hline \multirow{3}{*}{ Rotation } & \multicolumn{6}{|c|}{ Loss of nitrogen and carbon at- } \\
\hline & \multicolumn{2}{|c|}{ Hays } & \multicolumn{2}{|c|}{ Colby } & \multicolumn{2}{|c|}{ Garden City } \\
\hline & $\begin{array}{l}\text { Nitro- } \\
\text { gen }\end{array}$ & Carbon & $\begin{array}{l}\text { Nitro- } \\
\text { gen }\end{array}$ & Carbon & $\begin{array}{l}\text { Nitro- } \\
\text { gen }\end{array}$ & Carbon \\
\hline $\begin{array}{l}\text { Continuous small grain } \\
\text { Small grain, fallow }\end{array}$ & $\begin{array}{r}\text { Percent } \\
13.5 \\
13.4\end{array}$ & $\begin{array}{r}\text { Percent } \\
25.1 \\
27.7\end{array}$ & $\begin{array}{r}\text { Percent } \\
12.8 \\
23.8\end{array}$ & $\begin{array}{r}\text { Percent } \\
21.3 \\
27.8\end{array}$ & $\begin{array}{r}\text { Percent } \\
7.9 \\
9.8\end{array}$ & $\begin{array}{r}\text { Percent } \\
33.0 \\
25.0\end{array}$ \\
\hline $\begin{array}{l}\text { Including rye green- } \\
\text { manure }\end{array}$ & 15. 4 & 29. 0 & 26.6 & 33.8 & 15.5 & 35.1 \\
\hline $\begin{array}{l}\text { Including pea green- } \\
\text { manure }\end{array}$ & 16. 6 & 29. 4 & 32.9 & 43. 6 & 22.0 & 37. 4 \\
\hline Fallow, wheat, sorghum & 31.1 & 37.4 & 25.0 & 26.4 & 12.5 & 34. 2 \\
\hline Continuous row crop...... & 31.5 & 42. 0 & 27.0 & 40.4 & 30. 9 & 46. 3 \\
\hline Row crop, fallow... & 38. 4 & 51. 6 & 29. 9 & 44.1 & 27.7 & 40. 0 \\
\hline Mear & 22.8 & 34.6 & 25.4 & 33.9 & 18. 0 & 35.8 \\
\hline
\end{tabular}

1 Data from Hobbs and Brown ( 35 ).

2 Small grain, rye green-manure, small grain, row crop.

3 Small grain, pea green-manure, small grain, row crop. 


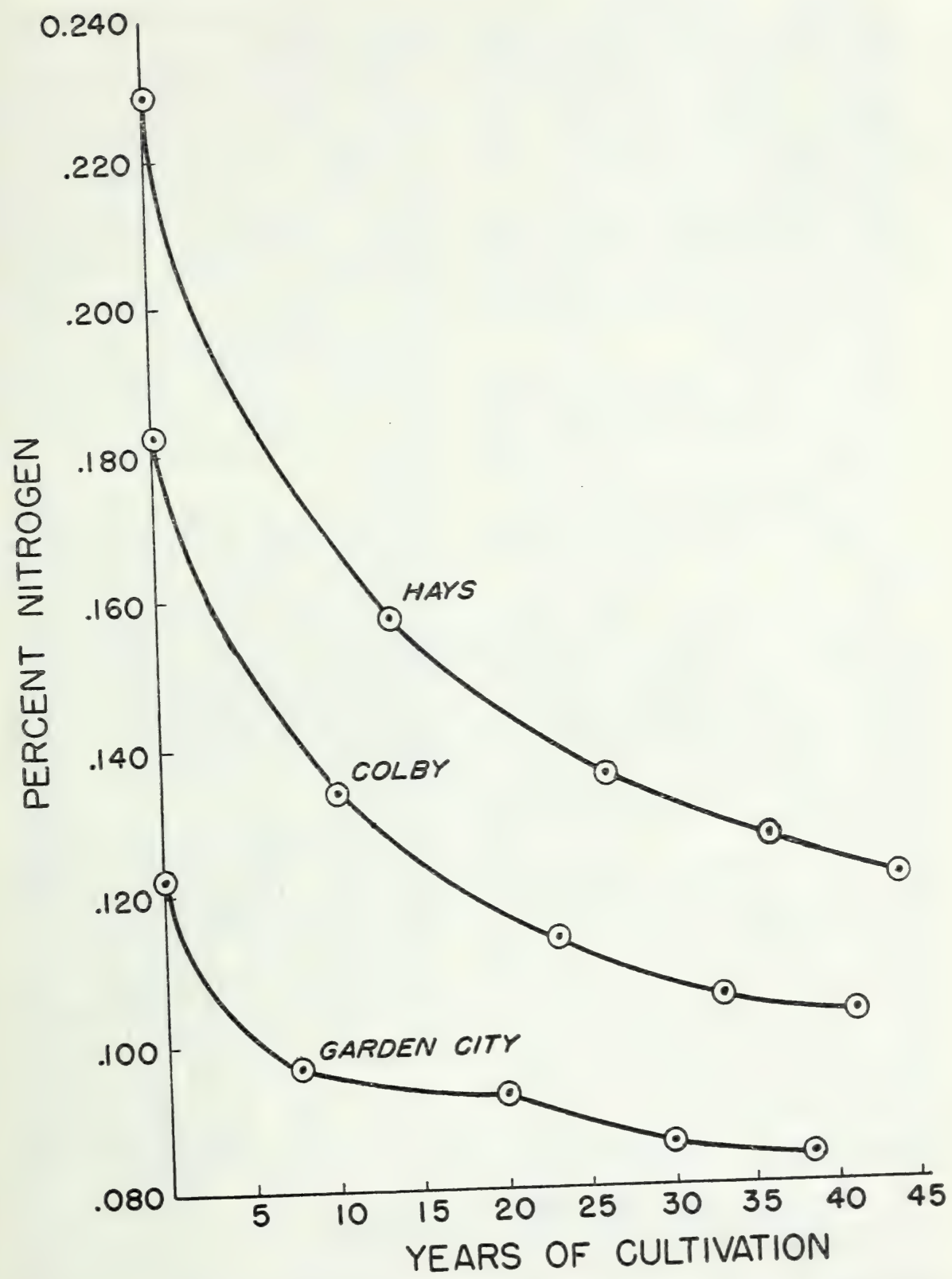

FigURE 3.-Effect of cultivation on nitrogen content of surface soils at Hays, Colby, and Garden City, Kans., 1916-46. Data from Hobbs and Brown (35). 
At Hays, green-manure rotations caused slightly greater nitrogen and carbon losses than continuous small grain or alternate small grain and fallow. Alternate row crop and fallow caused the greatest nitrogen and carbon losses.

At Colby, green-manure rotations caused large losses of soil nitrogen and carbon. These rotations were as destructive as continuous row crop and alternate row crop and fallow.

At Garden City, green-manure rotations were intermediate between continuous small grain and continuous row crop in soil nitrogen and carbon losses.

Reasons for the differential effects of green manures are not known. Soil erosion may have been a factor.

Hobbs and Brown (35) studied the effects of manure and straw applications on nitrogen and carbon losses at Hays. Manure applications reduced both nitrogen and carbon losses (fig. 4). However, 3 tons of straw was as effective as 3 tons of manure in reducing these losses (35).

Long extrapolations are questionable, but extrapolating the curves to zero nitrogen and carbon losses indicated that 24 to 30 tons of manure applied every 3 years may be necessary to maintain soil nitrogen and carbon. This is a fantastic figure for dryland areas where little manure is available.

Metzger (56) studied the nitrogen and organic-carbon contents of soils as influenced by cropping systems and soil treatments. This study was on the soil-fertility field plots at Manhattan for the period 1915 to 1934 . The soil was Geary silty clay loam. The cropping systems studied were a 16-year rotation (alfalfa, 4 years, and corn, wheat, wheat rotated for 12 years), a 3year rotation (corn, soybeans, wheat), continuous wheat, and continuous alfalfa.

The 16-year rotation led in the rate of loss of nitrogen, but the 3 -year rotation led in rate of loss of carbon. Corn dissipated nitrogen and carbon two to three times faster than rotation or continuous wheat. Alfalfa grown continuously increased the supply of nitrogen and carbon in the soil at the rate of 0.71 percent and 0.43 percent per year, respectively. Alfalfa, in continuous culture, continued to add to the supply of nitrogen in the soil for 19 years, although all topgrowth was regularly removed as hay.

Results from studies (56) of the nitrate content of the wheat plots previously cropped to alfalfa for periods up to 9 years indicate a rather sharp decline in nitrate production 6 years after plowing the alfalfa sod. Residual effects in nitrate accumulating capacity were evident for 8 years or more on all plots cropped to alfalfa for 2 years or longer.

Manured and green-manured plots maintained higher nitrogen and carbon levels than did control plots (56). Commercial fertilizer had a similar but less marked effect.

Fritschen and Hobbs (22) reported further studies on the soilfertility field plots at Manhattan in 1956. They determined the average nitrogen and carbon contents under three cropping systems for 1915-56 (fig. 5). All cropping systems showed losses of both nitrogen and organic carbon for the period of study. Greatest total losses of both nitrogen and organic carbon occurred in the 3-year rotation. Total losses of nitrogen from plots under the 16-year rotation (alfalfa for 4 years, and corn, wheat, wheat for 12 years) were significantly greater than those from plots in continuous wheat. Initial nitrogen level was higher for the 


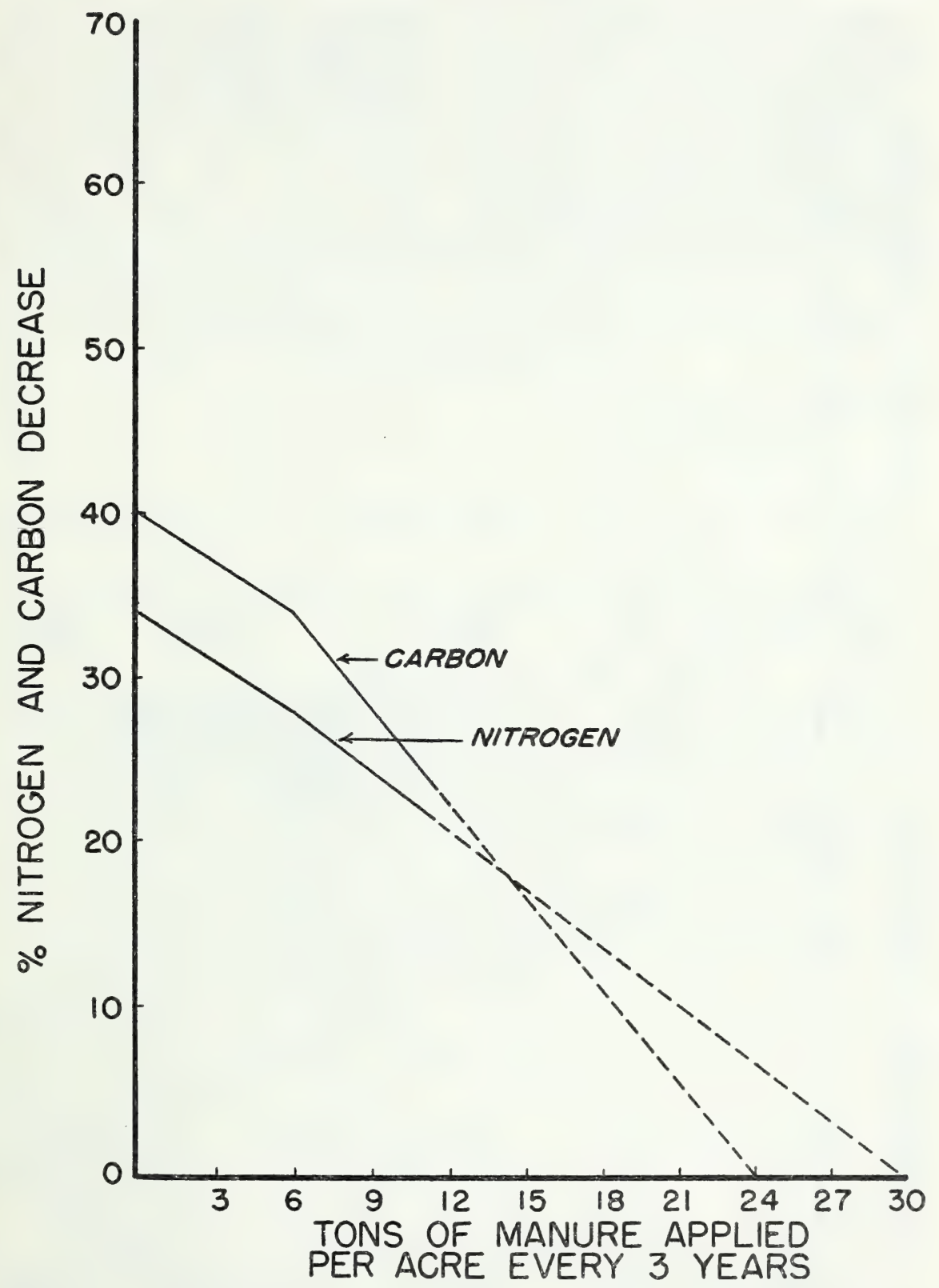

Figure 4.-Effects of manure (applied every 3 years) on nitrogen and carbon losses in a fallow, wheat, kafir rotation at Hays, Kans., 1916-46. Data from Hobbs and Brown (35). 

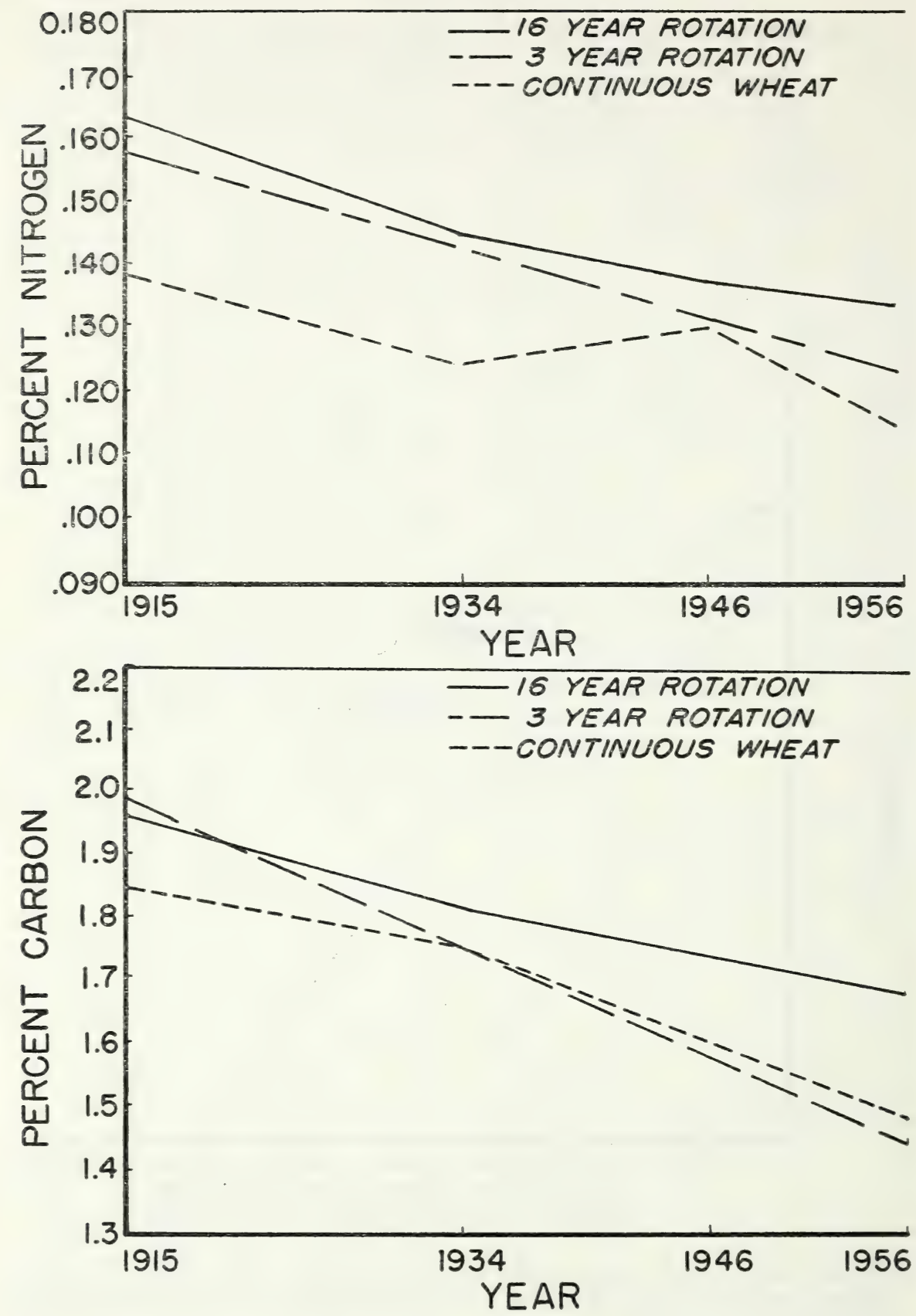

FigURE 5.-Average nitrogen and carbon content under three cropping systems as influenced by treatments and length of cultivation at Manhattan, Kans. Data from Fritschen and Hobbs (22). 
16-year rotation. Greater losses of nitrogen are attributed to corn. Fertilizers, including a combination of nitrogen, phosphorus, and potassium, were not effective in decreasing nitrogen and organic-carbon losses.

Olmstead (64) studied the effects of longtime cropping systems on soil aggregation at Hays in 1945 .
Plots studied were on the drvland agricultural project and adjacent fields of the experiment station. Soils were Munjor and Yocemento silty clay loam. He determined the percentage of water-stable aggregates under various cropping systems (table 28). By definition, water-stable aggregates were those larger than $0.2 \mathrm{~mm}$.

TABLE 28.-Percentage of water-stable aggregates at 2 depths in experimental fields, Hays, Kans., $1945^{1}$

\begin{tabular}{|c|c|c|c|c|c|c|}
\hline \multirow{3}{*}{$\begin{array}{l}\text { Item } \\
\text { number }\end{array}$} & \multirow{3}{*}{$\begin{array}{l}\text { Rotation } \\
\text { and plot }\end{array}$} & \multirow{3}{*}{ Cropping system } & \multicolumn{4}{|c|}{$\begin{array}{l}\text { Water-stable aggregates } \\
\text { larger than } 0.2 \mathrm{~mm} \text {. at a } \\
\text { depth of - }\end{array}$} \\
\hline & & & \multicolumn{2}{|c|}{$\begin{array}{l}1 \text { to } 5 \\
\text { inches }\end{array}$} & \multicolumn{2}{|c|}{$\begin{array}{l}7 \text { to } 11 \\
\text { inches }\end{array}$} \\
\hline & & & $\begin{array}{l}\text { Per- } \\
\text { cent }\end{array}$ & $\begin{array}{l}\text { Stand- } \\
\text { ard } \\
\text { error }\end{array}$ & $\begin{array}{l}\text { Per- } \\
\text { cent }\end{array}$ & $\begin{array}{l}\text { Stand- } \\
\text { ard } \\
\text { error }\end{array}$ \\
\hline 1 & $\mathrm{MC}-\mathrm{B}$ & Winter wheat, early plow_ & 9.8 & 1.4 & 38. 2 & 3.9 \\
\hline 2 & MC-I & Winter wheat, fallow...... & 5. 9 & 3 & 32.1 & 2. 0 \\
\hline$\overline{3}$ & $570-\mathrm{D}$ & $\begin{array}{l}\text { Winter wheat, fallow, fallow, } \\
\text { fallow. }\end{array}$ & 11. 9 & 2. 7 & 46. 9 & 1. 2 \\
\hline 4 & MC-D & Spring barley, fall plow....... & 13. 4 & 1. 0 & 42. 8 & 8 \\
\hline 5 & $560-$ & $\begin{array}{l}\text { Wheat, kafir, fallow, } 12 \text { tons } \\
\text { manure. }\end{array}$ & 10. 2 & .9 & 44. 2 & 2. 7 \\
\hline 6 & $92-\mathrm{A}_{-}$ & Wheat, corn, barley, peas & 9.8 & 1. 0 & 50.5 & 1. 5 \\
\hline 7 & $\mathrm{MC}-\mathrm{B}$ & $\begin{array}{l}\text { (green manure). } \\
\text { Kafir, fall plow_............... }\end{array}$ & 10. 5 & 1. 0 & 49. 6 & 1. 8 \\
\hline 8 & 501-A_ & $\begin{array}{l}\text { Fallow, wheat, kafir, plow } 14 \\
\text { inches deep. }\end{array}$ & 16.5 & .8 & 23. 1 & 1. 3 \\
\hline 9 & $591-$ & Wheat, stubbled-in, no tillage, & 46. 6 & 2. 0 & 57.4 & 2. 2 \\
\hline 10 & $\mathrm{C}-15-7$ & Wheat, stubble burned, no & 31.3 & 1. 2 & 45. 1 & 1. 5 \\
\hline 11 & C-15-8 & $\begin{array}{l}\text { tillage, } 10 \text { years. } \\
\text { Wheat, stubbled-in, no tillage, }\end{array}$ & 26.8 & 1.5 & 54. 5 & 1. 3 \\
\hline 12 & 141-A. & $\begin{array}{l}18 \text { years. } \\
\text { Buffalograss, } 1 \text { year... }\end{array}$ & 19. 7 & 1. 7 & 58. 9 & 1. 3 \\
\hline 13 & 141 & Buffalograss, 4 years.... & 25.8 & 1.5 & 55.5 & 1. 7 \\
\hline 14 & Range 10 & Weeds, no tillage, 3 years. & 5.2 & .7 & 30.6 & 2.6 \\
\hline 15 & Range 5 & Side-oats grama, 7 years & 21.8 & 1. 7 & 42. 5 & 1.9 \\
\hline 16 & Range 5. & Blue grama, 7 years.......... & 23. 0 & .6 & 55. 0 & 2. 1 \\
\hline 17 & Range 5_ & Buffalograss, 7 years & 25.3 & 1.5 & 55.7 & 1. 4 \\
\hline 18 & Range 5_ & Western wheatgrass, 7 years & 14. 7 & 1. 1 & 50. 1 & 2. 3 \\
\hline 19 & Range 5 & Switchgrass, 7 years........... & 18.1 & 1.4 & 50.8 & 1. 7 \\
\hline 20 & $\operatorname{Ran}$ & Little bluestem, 7 years. . . . . . & 18. 1 & 1. 0 & 52.8 & 1.8 \\
\hline 21 & Range 5. & Big bluestem, 7 years. . . & 17. 4 & .9 & 53. 7 & 2. 7 \\
\hline 22 & Range 3 & $\begin{array}{l}\text { Sweetclover, sweetclover, fal- } \\
\text { low, } 14 \text { years. }\end{array}$ & 12. 4 & .9 & 57.0 & 3.7 \\
\hline 23 & Project_ & Buffalograss, 28 years... & 60.2 & 3. 3 & 66.9 & 1. 6 \\
\hline 24 & & Native pasture & 56. 0 & 1. 7 & 61.8 & 1. 0 \\
\hline
\end{tabular}

1 Data from Olmstead (64). 
All plots showed approximately 80 percent loss of aggregation in the surface-tilled zone since the area was broken from sod about 1902. The lower half of the top foot of soil and the middle of the second foot showed only slightly lower aggregation than native pasture (64). There were practically no waterstable aggregates at 30 inches.

Field examination indicated that tilth was better on the small-grain plots than on the row-crop plots (table 28). Small-grain plots were loose, well granulated, and had a high infiltration capacity. Rowcrop plots were compact and massive with high volume weights. However, the well-granulated wheat plots did not have a higher content of water-stable aggregates than the row-crop plots. Data show that barnyard manure and green manures (rotations $560-\mathrm{A}$ and $92-\mathrm{A}$ ) had not significantly improved aggregation.

Items 9,10 , and 11 are of special interest. Plot 591-A had been continuously planted to wheat without tillage for 29 years. Plots $\mathrm{C}-15-7$ and $\mathrm{C}-15-8$ had been planted to continuous wheat without tillage for 18 years. These three plots showed high aggregation. Aggregation must be attributed to noncultivation on these plots. Average wheat yields were extremely low-less than 6 bushels per acre.

Grasses that had been seeded 7 vears (items 15 to 21 ) showed definite improvement in aggregation compared to nongrass plots. Western wheatgrass was least effective. Buffalograss was most effective, followed by blue grama. Four years of buffalograss doubled aggregation compared to nongrass plots.

Sweetclover was not effective as a soil-aggregating crop. Fourteen years of sweetclover, sweetclover, fallow produced only 12.4 percent water-stable aggregates in the plowed zone.
Myers and Myers (60) studied soil aggregation as a factor in yields after alfalfa at Manhattan. They made aggregate analyses of soil from legume and nonlegume rotations. Legume rotation was 2 years of alfalfa, row crop, oats, and wheat. Nonlegume rotation was row crop, oats, and wheat. They found approximately 50 percent higher total aggregation in samples taken before row crop and before oats from the legume rotations than in those taken from the nonlegume rotations. Improved aggregation lasted for about 2 years after the legumes were plowed. The breakdown of water-stable aggregates in the legume rotation coincided with small-grain yields in the rotations. The legume rotations increased oats yields an average of 6.7 bushels over yields from the nonlegume rotation, but increased wheat yields only 1.1 bushels. Row-crop yields were erratic because summer drought reduced yields and appeared to mask any favorable effect of the legumes.

The authors believed that increased small-grain yields were caused by favorable soil structure created by the legumes rather than from their influence on soil nitrogen.

Chepil (9) mixed dry wheat straw and freshly cut alfalfa hay with five Kansas soils and exposed them under field conditions. After partial decomposition, he found that straw and alfalfa hay had increased the proportion of waterstable particles greater than 0.84 $\mathrm{mm}$. in diameter, decreased the proportion of water-stable particles smaller than $0.02 \mathrm{~mm}$., increased the proportion of dry soil clods greater than $0.84 \mathrm{~mm}$., and slightly decreased erodibility of soil by wind. Effects were more pronounced with large amounts of added vegetative matter.

After 2 to 5 years, his results show that the decomposed vege- 
tative matter or decomposition products had little or no influence on the proportion of water-stable aggregates greater than $0.84 \mathrm{~mm}$., but they increased the proportion of medium-sized water-stable aggregates, decreased the proportion of water-stable aggregates less than $0.02 \mathrm{~mm}$., decreased soil cloddiness, and increased wind erosion. He concluded that far greater protection from wind erosion would be derived from maintenance of vegetative materials on the soil surface than from mixing them into the soil to increase soil aggregation during the initial stage of their decomposition.

\section{Summary}

Yields of all crops on greenmanure fallow were less than those on ordinary fallow at Hays and Colby. Yield reductions were caused by reduced moisture storage. Green-manure fallow crops had used part of the moisture normally stored by ordinary fallow. There was no cumulative benefit from their use.

Crop rotations and fertilizer treatments have been studied at Manhattan since 1915. Grain yields on unfertilized plots declined with time in all but the alfalfa rotation. In both legume and nonlegume rotations, there. was an upward trend in wheat vields with time where commercial fertilizer or manure was used. In all rotations except the 16-year rotation that included 4 years of alfalfa, there was a downward trend in corn yields where commercial fertilizer or manure was used. There was a downward trend in alfalfa yields regardless of fertilizer treatment.

At Manhattan, alfalfa depleted available soil moisture to a depth of 25 feet. Two years of fallow with normal precipitation restored depleted soil-moisture reserves.
From 1919 to 1928, continuous cereal cropping failed to restore soil-moisture reserves depleted by alfalfa. However, from 1938 to 1949, 12 years of cereal cropping resulted in water being stored to a depth of at least 22 feet. From October 1941 to October 1945, total precipitation exceeded longtime totals by 36.6 inches. Soilmoisture samples were not taken, but most of the water probably was stored during this period.

At Manhattan, sweetclover reduced subsoil moisture to a depth of 9 feet in 1 year and 14 feet in 2 years. Bromegrass did not deplete the soil moisture below 4 feet.

Soil nitrogen and carbon changes have been measured periodically at the Hays, Colby, and Garden City Branch Stations since 1916. At Hays, green-manure rotations have been less effective than continuous small grains in conserving soil nitrogen and carbon. At Colby, green-manure rotations caused nitrogen and carbon losses as great as continuous row crop. At Garden City, green-manure rotations were intermediate between continuous small grain and continuous row crop in soil nitrogen and carbon losses. Reasons for the differential effects of green manure are not known.

At Manhattan, none of the crop rotations or fertilizer treatments maintained the nitrogen and carbon content of the soil at its original level. Green manures reduced carbon and nitrogen losses. Commercial fertilizer had a similar but less marked effect.

Alfalfa grown continuously at Manhattan increased the supply of nitrogen and carbon in the plow layer of soil at the rate of 0.71 percent and 0.43 percent per year, respectively. Alfalfa added to the supply of soil nitrogen for 19 yearsthe duration of the experiment. Wheat grain yields were increased 
for 3 years and protein content was increased for 8 years after plowing the alfalfa sod. Nitrate production capacity showed a sharp decline 6 years after the alfalfa sod was plowed.

Seeded grasses increased aggregation at Hays. Buffalograss was the most effective of seven grasses tested. The most rapid increase in aggregation was brought about in 4 or 5 years. Twenty-eight years of buffalograss restored aggregation to the same level as native pasture. How long this aggregation would last when the grass sod is plowed is unknown.

Continuous wheat, stubbled-in without tillage, showed greater soil aggregation than other cropping systems. However, yields from stubbled-in wheat were too low to be profitable.

All cultivated plots at Hays showed low aggregation in the plow layer.

\section{Yields}

\section{Colorado}

In 1944, Brandon and Mathews (3) published the results of dryland rotations and tillage experiments at the Akron (Colorado) Field Station for 1909-38. The soil is Rago silt loam. Annual precipitation averaged 17.1 inches. They tabulated data on yields of winter wheat, spring wheat, and oats after greenmanure fallow, continuous cropping, and ordinary fallow (table 29).

Crops after green-manure fallow yielded less than crops on ordinary fallowed land. Yields after the green manures were related to the moisture used by the green-manure crop. Yields were highest after winter rye, next highest after peas, and lowest after sweetclover. Winter rye was plowed under early; peas and sweetclover were plowed under about a month later than winter rye. Sweetclover grew more vigorously than peas and used more soil moisture. Moisture limitations prevented the crops from making productive use of any greater fertility that resulted from green manuring, because burning due to overstimulation was frequently evident.

Second-and third-year yields after green-manure crops were no higher than those in rotations containing ordinary fallow; usually they were lower.

In two 6-year rotations, bromegrass and alfalfa were grown for 3

TABLE 29.-Average yields of winter wheat, spring wheat, and oats after green-manure fallow, continuous cropping, and ordinary fallow, Akron, Colo., 1909-38 ${ }^{1}$

\begin{tabular}{|c|c|c|c|c|c|}
\hline \multirow{3}{*}{ Crop } & \multicolumn{5}{|c|}{$\begin{array}{c}\text { Average yield, per acre, under (previous crop or } \\
\text { treatment) - }\end{array}$} \\
\hline & \multicolumn{3}{|c|}{ Green-manure fallow } & \multirow{2}{*}{$\begin{array}{l}\text { Continuous } \\
\text { cropping }\end{array}$} & \multirow{2}{*}{$\begin{array}{l}\text { Ordinary } \\
\text { fallow }\end{array}$} \\
\hline & Rye & Pea & $\begin{array}{l}\text { Sweet- } \\
\text { clover }\end{array}$ & & \\
\hline $\begin{array}{l}\text { Winter wheat.- } \\
\text { Spring wheat. } \\
\text { Oats. }\end{array}$ & $\begin{array}{r}\text { Bushels } \\
11.4 \\
7.7 \\
20.3\end{array}$ & $\begin{array}{r}\text { Bushels } \\
9.0 \\
6.8 \\
17.9\end{array}$ & $\begin{array}{r}\text { Bushels } \\
5.9 \\
15.6\end{array}$ & $\begin{array}{r}\text { Bushels } \\
7.1 \\
7.8 \\
16.3\end{array}$ & $\begin{array}{r}\text { Bushels } \\
16.3 \\
10.2 \\
27.7\end{array}$ \\
\hline
\end{tabular}

1 Data from Brandon and Mathews (\$). 
consecutive years followed by oats, corn, and spring wheat (table 30 ). Oat yields after 3 years of alfalfa and bromegrass were reduced when compared with yields after 3 years of wheat; the reduction probably was caused by dry soil conditions. The second and third crops after alfalfa and bromegrass also were reduced.

The authors concluded that grass should be grown for an indeterminate period rather than be made a definite part of rotations.

\section{Summary}

Yields of winter wheat, spring wheat, and oats after green-manure fallow were substantially lower than those after ordinary fallow. The second and third crops after green manures tended to yield less than those in comparable rotations with fallow.

Bromegrass and alfalfa grown for 3 years reduced the yields of oats, corn, and spring wheat that were grown during the succeeding 3 years.

TABLE 30.-Average grain yields of oats, corn, and spring wheat in alfalfa, bromegrass, and nonsod rotations, Akron, Colo., 1909-38 ${ }^{1}$

\begin{tabular}{|c|c|c|c|}
\hline \multirow{2}{*}{ Previous 3-year crop } & \multicolumn{3}{|c|}{ Average yield, per acre, for- } \\
\hline & $\begin{array}{l}\text { First } \\
\text { crop, } \\
\text { oats }\end{array}$ & $\begin{array}{l}\text { Second } \\
\text { crop, } \\
\text { corn }\end{array}$ & $\begin{array}{l}\text { Third } \\
\text { crop, spring } \\
\text { wheat }\end{array}$ \\
\hline $\begin{array}{l}\text { Bromegrass } \\
\text { Alfalfa } \\
\text { Wheat }\end{array}$ & $\begin{array}{r}\text { Bushels } \\
12.0 \\
12.1 \\
16.4\end{array}$ & $\begin{array}{r}\text { Bushels } \\
7.8 \\
8.5 \\
10.6\end{array}$ & $\begin{array}{r}\text { Bushels } \\
5.8 \\
6.6 \\
8.8\end{array}$ \\
\hline
\end{tabular}

1 Data from Brandon and Mathews (3).

\section{CARBON AND NITROGEN CHANGES IN SOILS AT 10 DRYLAND EXPERIMENT STATIONS}

In 1957, Haas and coworkers (27) reported on the nitrogen and carbon changes of soils from 17 experiment stations in the Great Plains. Ten of these stations were in the northern and central Great Plains. The stations were estab- lished in the early part of the 20th century to study the effects of different rotations and tillage practices on crop production under dryland conditions. The following list shows the designations and locations of the 10 stations.

Experiment Station:

Location.

United States Northern Great Plains Field Station....... Mandan, N. Dak.

Dickinson Substation.

North Montana Branch Station......................Havre, Mont.

Central Montana Branch Station... Moceasin, Mont.

Sheridan Substation. . . .

Archer Substation.

United States Akron Field Station...............................

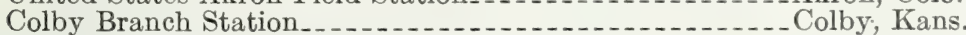

Fort Hays Branch Station

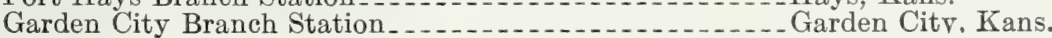


These drrland stations provided excellent opportunity to study changes in soil nitrogen as influenced by different cropping systems over a wide range of soil and climatic conditions.

Purposes of this study were: (1) to determine the effects of cropping on the total nitrogen and carbon contents of various dryland soils; (2) to evaluate the relationship of total nitrogen in the soil to the capacity of that soil to produce nitrate-nitrogen; and (3) to show the influence of the changes in soil nitrogen on crop yields.

Changes in total nitrogen in the surface 6 inches of soil at the 10 locations were tabulated (table 31 ).

Average loss of nitrogen was 36 percent in 37 years. This was a 0.98-percent loss of nitrogen for each year of cropping. Percentage reduction in nitrogen content caused by cultivation and cropping was relatively constant, even though there was wide variation in total nitrogen content of the virgin soils.

Changes in organic carbon in the surface 6 inches of soil at the same 10 locations were tabulated (table 32).

Annual carbon loss averaged 1.17 percent over a 37-year period. Cropping caused greater organiccarbon losses than nitrogen losses.

Nitrogen and carbon losses from the 6- to 12-inch depth at Mandan, Dickinson, Havre, Sheridan, Archer, and Akron were also measured (27). An average of 15 percent of the nitrogen and 20 percent of the carbon was lost during 35 years of cropping.

Losses of soil nitrogen and carbon were measured for several small grains (27). Haas and coworkers found no indication that one small grain influenced nitrogen and carbon losses more than any other.

Percentage change in nitrogen and carbon content of the surface and subsurface soils in rotations with and without green manures were tabulated (tables 33 and 34).

TABLE 31.-Total nitrogen in surface 6 inches of virgin soils and soils cropped for an average of 37 years and the total and per-year percentage loss caused by cropping, 10 locations in the northern and central Great Plains ${ }^{1}$

\begin{tabular}{|c|c|c|c|c|c|c|}
\hline \multirow[b]{2}{*}{ Location } & \multirow{2}{*}{$\begin{array}{l}\text { Cropping } \\
\text { period }\end{array}$} & \multirow{2}{*}{$\begin{array}{l}\text { Years } \\
\text { of } \\
\text { crop- } \\
\text { ping }\end{array}$} & \multicolumn{4}{|c|}{ Total nitrogen content } \\
\hline & & & $\begin{array}{l}\text { Virgin } \\
\text { soils }\end{array}$ & $\begin{array}{l}\text { Cropped } \\
\text { soils }\end{array}$ & $\begin{array}{l}\text { Loss } \\
\text { with } \\
\text { erop- } \\
\text { ping }\end{array}$ & $\begin{array}{l}\text { Loss per } \\
\text { year of } \\
\text { crop- } \\
\text { ping }\end{array}$ \\
\hline $\begin{array}{l}\text { Mandan, N. Dak. } \\
\text { Dickinson, N. Dak. } \\
\text { Havre, Mont. } \\
\text { Moccasin, Mont. } \\
\text { Sheridan, Wyo } \\
\text { Archer, Wyo } \\
\text { Akron, Colo } \\
\text { Colby, Kans } \\
\text { Hays, Kans } \\
\text { Garden City, Kans. }\end{array}$ & $\begin{array}{l}1913-43 \\
1907-47 \\
1916-47 \\
1908-47 \\
1917-47 \\
1913-47 \\
1908-47 \\
1905-46 \\
1903-46 \\
1907-46\end{array}$ & $\begin{array}{r}\text { Number } \\
30 \\
40 \\
31 \\
39 \\
30 \\
34 \\
39 \\
41 \\
43 \\
39\end{array}$ & $\begin{array}{r}\text { Percent } \\
0.160 \\
.293 \\
.151 \\
.300 \\
.159 \\
.122 \\
.134 \\
.165 \\
.220 \\
.120\end{array}$ & $\begin{array}{r}\text { Percent } \\
0.116 \\
.149 \\
.090 \\
.205 \\
.121 \\
.082 \\
.086 \\
.105 \\
.122 \\
.077\end{array}$ & $\begin{array}{r}\text { Percent } \\
28 \\
49 \\
40 \\
32 \\
24 \\
33 \\
36 \\
36 \\
45 \\
36\end{array}$ & $\begin{array}{r}\text { Percent } \\
0.93 \\
1.23 \\
\text { 1. } 29 \\
.82 \\
.80 \\
.97 \\
.92 \\
.88 \\
1.05 \\
.92\end{array}$ \\
\hline Mear & 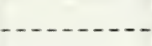 & 37 & 0.182 & 0.115 & 36 & 0.98 \\
\hline
\end{tabular}

${ }_{1}$ Data from Haas and coworkers (27). 
TABLE 32.-Organic carbon in surface 6 inches of virgin soils and soils cropped for an average of 37 years and the total and per-year percentage loss caused by cropping, 10 locations in the northern and central Great Plains ${ }^{1}$

\begin{tabular}{|c|c|c|c|c|c|c|}
\hline \multirow[b]{2}{*}{ Location } & \multirow{2}{*}{$\begin{array}{l}\text { Cropping } \\
\text { period }\end{array}$} & \multirow{2}{*}{$\begin{array}{l}\text { Years } \\
\text { of } \\
\text { crop- } \\
\text { ping }\end{array}$} & \multicolumn{4}{|c|}{ Organic-carbon content } \\
\hline & & & $\begin{array}{l}\text { Virgin } \\
\text { soils }\end{array}$ & $\begin{array}{c}\text { Cropped } \\
\text { soils }\end{array}$ & $\begin{array}{l}\text { Loss } \\
\text { with } \\
\text { crop- } \\
\text { ping }\end{array}$ & $\begin{array}{l}\text { Loss per } \\
\text { year of } \\
\text { crop- } \\
\text { ping }\end{array}$ \\
\hline $\begin{array}{l}\text { Mandan, N. Dak } \\
\text { Dickinson, N. Dak } \\
\text { Havre, Mont } \\
\text { Moccasin, Mont } \\
\text { Sheridan, Wyo } \\
\text { Archer, Wyo } \\
\text { Akron, Colo } \\
\text { Colby, Kans } \\
\text { Hays, Kans } \\
\text { Garden City, Kans }\end{array}$ & $\begin{array}{l}1913-43 \\
1907-47 \\
1916-47 \\
1908-47 \\
1917-47 \\
1913-47 \\
1908-47 \\
1905-46 \\
1903-46 \\
1907-46\end{array}$ & $\begin{array}{r}\text { Number } \\
30 \\
40 \\
31 \\
39 \\
30 \\
34 \\
39 \\
41 \\
43 \\
39\end{array}$ & $\begin{array}{r}\text { Percent } \\
\text { 2. } 11 \\
\text { 3. } 64 \\
\text { 1. } 75 \\
\text { 3. } 24 \\
\text { 1. } 66 \\
\text { 1. } 33 \\
\text { 1. } 42 \\
\text { 1. } 83 \\
\text { 2. } 47 \\
\text { 1. } 13\end{array}$ & $\begin{array}{r}\text { Percent } \\
1.45 \\
1.51 \\
.83 \\
2.19 \\
1.19 \\
.78 \\
.77 \\
1.01 \\
1.21 \\
.69\end{array}$ & $\begin{array}{r}\text { Percent } \\
31 \\
59 \\
53 \\
32 \\
28 \\
41 \\
46 \\
45 \\
51 \\
39\end{array}$ & $\begin{array}{r}\text { Percent } \\
\text { 1. } 03 \\
\text { 1. } 48 \\
\text { 1. } 71 \\
.85 \\
.93 \\
\text { 1. } 21 \\
\text { 1. } 18 \\
\text { 1. } 10 \\
\text { 1. } 19 \\
\text { 1. } 00\end{array}$ \\
\hline Mean_... & - & 37 & 2. 06 & 1. 16 & 42 & 1. 17 \\
\hline
\end{tabular}

1 Data from Haas and coworkers (27).

TABLE 33.-Losses of nitrogen from surface and subsurface soils compared with virgin sod in rotations with and without green manure at 10 locations in the northern and central Great Plains, 1903-4712

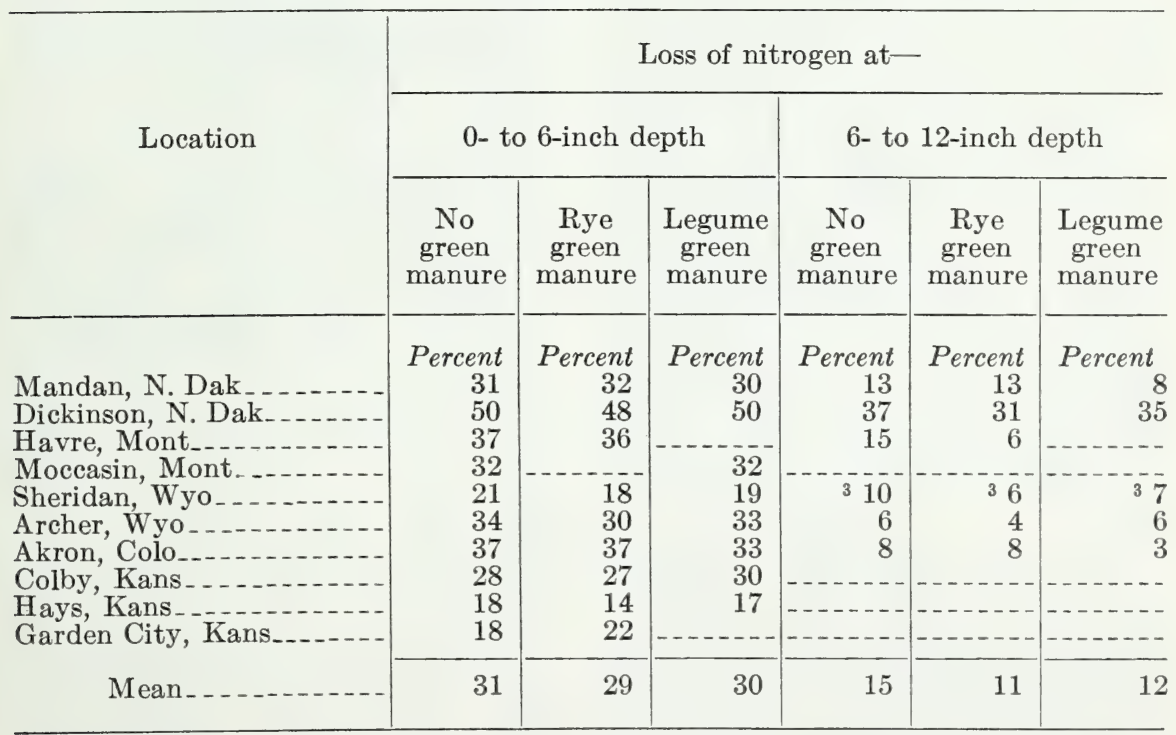

1 Data from Haas and coworkers (27)

2 Periods of cropping varied from 30 to 40 years.

3 Sampling depth was 6 to 20 inches. 
TABLE 34.- - Losses of organic carbon in surface and subsurface soils compared with virgin sod in rotations with and without green manure at 7 locations in the northern and central Great Plains, 1903-4712

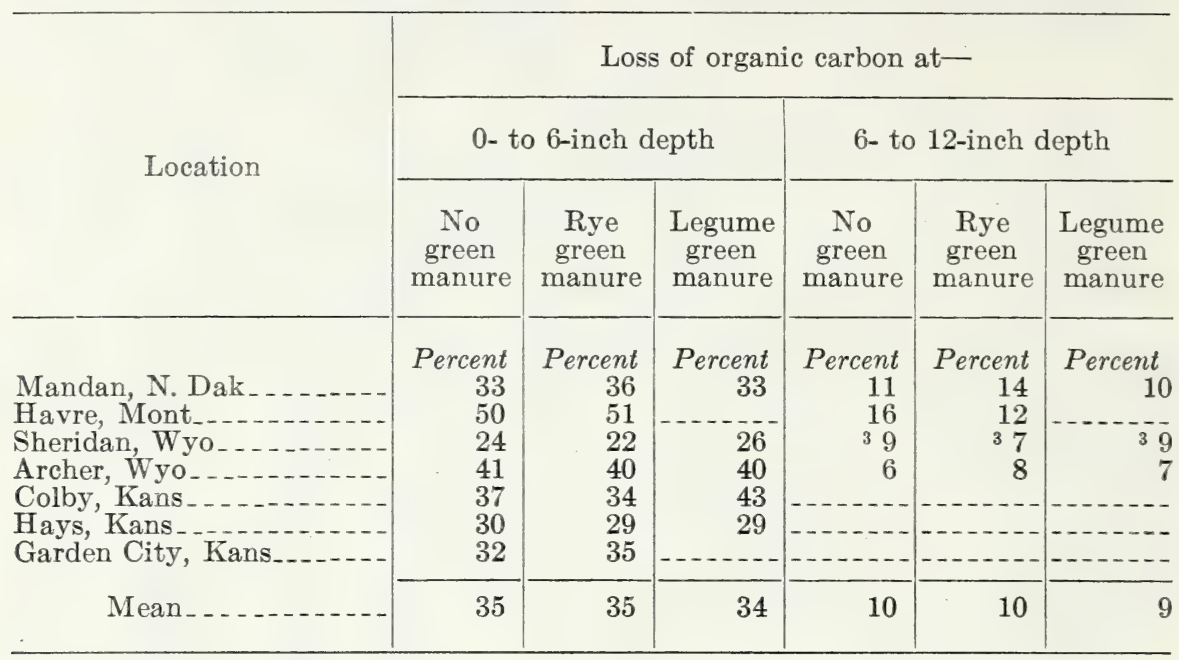

1 Data from Haas and coworkers (27).

2 Periods of cropping varied from 30 to 34 years.

3 Sampling depth was 6 to 20 inches.

Legumes used were sweetclover, cowpeas, and field peas. These were plowed in spring or early summer and the land fallowed the rest of the season. Data indicate that neither rye nor legume green manures were effective in reducing nitrogen and carbon losses.

At Sheridan, Wyo., one plot was planted to peas continuously for 30 years (27). The crop was plowed under for green manure each year. Soil from this plot lost 28 percent of its nitrogen, which was as high as from row-crop and small-grain rotations, where the crops were removed. Wind and water erosion was a problem on this plot, which probably accounted for some of the loss.

The results obtained in this study (27) indicated that green manures have been of little or no value in reducing the loss of nitrogen under dryland conditions in the northern and central Great Plains.

Nitrogen and carbon changes of surface and subsurface soils of rotations with and without grass and alfalfa were tabulated (table 35). Grass and alfalfa rotations consisted of six plots each. Three of these plots were in grass or alfalfa and three were in a rotation of corn, wheat, and oats.

Data indicate that grass and alfalfa rotations reduced nitrogen and carbon losses at Mandan and Sheridan but had little effect at Dickinson and Archer. It appeared that alfalfa was adding nitrogen to the soil at Mandan but not in sufficient quantities to maintain the soil at its original level. The losses from these rotations were substantially the same as from plots continually cropped to small grains.

As a part of this same study, Haas and coworkers (27) determined the nitrate-production capacity of northern and central Great Plains soils. High-nitrogen soils at most locations maintained a higher level of nitrate production than did the 
TABLE 35.-Changes in nitrogen and organic-carbon content in surface and subsurface soils compared with virgin sod in rotations with and without grass or alfalfa at several locations in the northern and central Great Plains, $1906-47^{12}$

\begin{tabular}{|c|c|c|c|c|c|c|}
\hline \multirow{3}{*}{ Location } & \multicolumn{6}{|c|}{ Gain or loss of nitrogen at- } \\
\hline & \multicolumn{3}{|c|}{0 - to 6-inch depth } & \multicolumn{3}{|c|}{ 6- to 12 -inch depth } \\
\hline & $\begin{array}{l}\text { Rota- } \\
\text { tion } \\
\text { without } \\
\text { grass or } \\
\text { alfalfa }\end{array}$ & $\begin{array}{l}\text { Grass } \\
\text { and } \\
\text { grain } \\
\text { rotation }\end{array}$ & $\begin{array}{l}\text { Alfalfa } \\
\text { and } \\
\text { grain } \\
\text { rotation }\end{array}$ & $\begin{array}{l}\text { Rota- } \\
\text { tion } \\
\text { without } \\
\text { grass or } \\
\text { alfalfa }\end{array}$ & $\begin{array}{l}\text { Grass } \\
\text { and } \\
\text { grain } \\
\text { rotation }\end{array}$ & $\begin{array}{l}\text { Alfalfa } \\
\text { and } \\
\text { grain } \\
\text { rotation }\end{array}$ \\
\hline $\begin{array}{l}\text { Mandan, N. Dak } \\
\text { Dickinson, N. Dak } \\
\text { Sheridan, Wyo } \\
\text { Archer, Wyo }\end{array}$ & $\begin{array}{r}\text { Percent } \\
-31 \\
-49 \\
-27 \\
-34\end{array}$ & $\begin{array}{r}\text { Percent } \\
-25 \\
-13 \\
-30\end{array}$ & $\begin{array}{r}\text { Percent } \\
-18 \\
-44 \\
-18 \\
-35\end{array}$ & $\begin{array}{r}\text { Percent } \\
-13 \\
-30 \\
-10 \\
-6\end{array}$ & \begin{tabular}{r} 
Percent \\
-6 \\
\hdashline $3-8$ \\
-3
\end{tabular} & $\begin{array}{r}\text { Percent } \\
+3 \\
-31 \\
3-5 \\
-9\end{array}$ \\
\hline \multirow[t]{2}{*}{ Mean } & -35 & -23 & -29 & -15 & -6 & -10 \\
\hline & \multicolumn{6}{|c|}{ Gain or loss of organic carbon } \\
\hline $\begin{array}{l}\text { Mandan, N. Dak } \\
\text { Sheridan, Wyo } \\
\text { Archer, Wyo }\end{array}$ & $\begin{array}{l}-36 \\
-31 \\
-41\end{array}$ & $\begin{array}{l}-29 \\
-20 \\
-38\end{array}$ & $\begin{array}{l}-24 \\
-26 \\
-44\end{array}$ & $\begin{array}{r}-13 \\
-10 \\
-6\end{array}$ & $\begin{array}{c}-8 \\
--4\end{array}$ & \\
\hline Mean.... & -36 & -29 & -31 & -10 & -6 & -2 \\
\hline
\end{tabular}

Data from Haas and coworkers ( 27$)$.

3 Periods of cropping varied from 30 to 40 years.

8 Sampling depth was 6 to 20 inches.

low-nitrogen soils. The highnitrogen soils produced a greater quantity of nitrate-nitrogen and were able to maintain production for a longer time. The results indicate that not only was the total nitrogen content of the soils reduced an average of 36 percent but the quantity of nitrate-nitrogen produced by these soils was also reduced by almost the same percentage.

The effects of number of years of cropping on crop yields were studied by means of multiple regression analyses of the data from Mandan, Dickinson, Havre, Sheridan, Archer, and Hays (27). There were two independent variables-precipitation and the years of cropping.
The dependent variable was yield. Results showed that corn and kafir yields were significantly reduced by cropping at some locations but that wheat yields were not.

When the percentage changes in soil nitrogen were compared with the percentage change in yield, there was little relationship between the two (27). In some instances, yield changes were greater than the nitrogen changes; while in others, the reverse was true.

\section{Summary}

The effects of cropping systems on the carbon and nitrogen content of the soils at 10 locations in the northern and central Great Plains were studied. Nitrogen losses av- 
eraged 36 percent for the 37-year period. Losses of organic carbon averaged 42 percent. Neither legume nor rye green manures were effective in reducing nitrogen and carbon losses.

Rotational effects of grass and alfalfa on the loss of soil nitrogen were studied at Mandan, Dickinson, Sheridan, and Archer. Except for alfalfa at Archer, grass and alfalfa reduced nitrogen losses in the surface soil. Neither grass nor alfalfa maintained the nitrogen at its original level. Losses of total nitrogan from the soils resulted in similar losses of nitrate-nitrogen producing capacity.

Data from Mandan, Dickinson, Havre, Sheridan, Archer, and Hays indicated that row-crop yields declined with years of cropping, while wheat yields did not change significantly. There was little relationship between the change in soil nitrogen and the change in yield.

\section{CANADIAN PRAIRIE PROVINCES SOIL-MANAGEMENT PROBLEMS}

\section{Yields}

Results from the Prairie Provinces of Alberta, Saskatchewan, and Manitoba are presented to complete the findings for the northern Great Plains. In 1911, the Dominion Experimental Farm Systems established comprehensive experiments in the Prairie Provinces to test the value of different crop rotations.

Hopkins and Barnes (36) reported the yields from these rotations in 1928. One of the experiments was conducted to determine the value of plowing under legume crops in 3-year rotations of green-manure fallow, wheat, and oats (table 36).

These experiments showed that yields were not increased by plowing under peas or vetch.

In 1944, Hopkins and Leahey (37) published a second report on the results of crop-rotation experiments conducted on the Dominion Experimental Farms in the Prairie Provinces. This report covered more than 30 years of records from different cropping systems. An important objective of the report

TABLE 36.-Average yields of spring wheat and oats in 3-year rotations with various treatments during the fallow year, Brandon, Manitoba, and Indian Head, Saskatchewan, $1928^{1}$

\begin{tabular}{|c|c|c|c|c|}
\hline \multirow{3}{*}{ Treatment during fallow year } & \multicolumn{4}{|c|}{ Average yield, per acre, at- } \\
\hline & \multicolumn{2}{|c|}{ Brandon } & \multicolumn{2}{|c|}{ Indian $\mathrm{Head}$} \\
\hline & $\begin{array}{c}\text { Spring } \\
\text { wheat, } \\
15 \text {-y ear } \\
\text { means }\end{array}$ & $\begin{array}{l}\text { Oats, } \\
\text { 13-year } \\
\text { means }\end{array}$ & $\begin{array}{l}\text { Spring } \\
\text { wheat, } \\
\text { 9-year } \\
\text { means }\end{array}$ & $\begin{array}{l}\text { Oats, } \\
\text { 9-year } \\
\text { means }\end{array}$ \\
\hline $\begin{array}{l}\text { Summer fallow } \\
\text { Peas plowed under early July } \\
\text { Vetch plowed under late July }\end{array}$ & $\begin{array}{r}\text { Bushels } \\
34.7 \\
33.8 \\
32.8\end{array}$ & $\begin{array}{r}\text { Bushels } \\
71.1 \\
72.0 \\
68.3\end{array}$ & $\begin{array}{r}\text { Bushels } \\
34.2 \\
33.5 \\
35.5\end{array}$ & $\begin{array}{r}\text { Bushels } \\
55.6 \\
56.0 \\
55.0\end{array}$ \\
\hline
\end{tabular}

1 Data from Hopkins and Barnes (36). 
was a comparison between graincrop rotations and the so-called mixed-farming rotations, which included legume and nonlegume hay and intertilled crops.

Beneficial effects of mixed-farming rotations over straight-grain rotations were outstanding in the Black and Gray wooded soil zones. In the drier Brown and Dark Brown soil zones, these rotations possessed no advantage over grain rotations. Discussion of results at Lethbridge, Alberta; and Swift Current and Indian Head, Saskatchewan follow.

Lethbridge, Alberta.-The experiments were located on Dark Brown (Chestnut) loam soil. Annual precipitation averaged 15.8 inches. Results with mixed-farming on dryland were not satisfactory. Weeds were controlled in grain rotations as effectively as in mixed-farming rotations. Yields from biennial or perennial hay crops were low and usually contdined a large amount of weeds in the first year after seeding. Pea and oat hay alone yielded two to three times as much hay as biennial or perennial hay crops. In grain rotations, farm manures and legume hay crops on dryland did not increase yields of the following crop over yields without these practices. Summer fallow wheat yields were exceptionally good in the grain rotations and did not tend to decline.

Swift Current, Saskatchewan.The experiments were located on Haverhill loam soil (Brown soil). Annual precipitation averaged 14.5 inches. The mixed-farming rotation was a failure. Wheat yields after grass were depressed. The hay crop usually included large amounts of weeds, so quality was poor. Yields of oat hay were much larger than those of biennial or perennial hay. Where hay crops were grown, it was concluded that the crop should be left in production for several years.
Indian Head, Saskatchewan.Experiments were located on Black Indian Head clay soil (Chernozem). Annual precipitation averaged 17.7 inches. A serious disadvantage of the fallow, wheat, wheat rotation was infestation with wild oats, especially in the second-year wheat crop. Hay crops did not yield well. Stands were difficult to obtain in a dry year, and the first-year hay always contained a large percentage of weeds. The authors concluded that hay should be left in production for several years rather than used for 1 or 2 years in a grain rotation. Oat hay yielded more than perennial hay crops.

Hopkins and Leahey (37) concluded that plowing under a crop for green manure was not advisable in the Prairie Provinces. Usually the yields of wheat the following year were less than were obtained after a regular summer fallow. In areas with sufficient moisture, it was preferable to harvest the crop for hay rather than plow it under for green manure.

They found that, in the Black soil zone (Chernozem), yields from a straight-grain rotation declined with time. Originally the grain rotations produced the greatest yields, but by 1944, mixed-farming rotations were superior.

In 1948, Doughty (14) discussed the maintenance of organic matter in Brown soils. Crop-yield data in the Brown soil zones of Alberta and Saskatchewan did not indicate any appreciable decrease in yield during the previous 25- to 30-year period. Yields showed a decrease during the first 4 to 5 years after plowing the sod. After this initial period, yields showed no decrease that could be attributed to a loss in productivity.

Loss of nitrogen and organic carbon after plowing grass sod was more rapid than the accumulation when grass was reestablished (14). 
Return of all crop residue was recommended as the most practical way to compensate for losses of organic matter from medium- and fine-textured soils of the Brown soil zone. For coarse-textured soil, grass seeding was generally recommended.

In 1954, Hill (29, 30) discussed wheat yields and soil fertility on the Canadian Prairies after a half century of farming. Cereal production alternating with fallow was the usual cropping practice in the Brown soil zones of southern Alberta and Saskatchewan where moisture was a limiting factor. Continued use of the practice was of chief concern to farmers and agronomists in the area.

Hill (30) tabulated the long-term and 10-year average yields of continuous wheat and fallow wheat at Lethbridge, Alberta (table 37). The data indicate that yields did not decline with time with these cropping systems.

Hill (30) found that during 40 years of cropping at Lethbridge, average losses of 25 percent nitrogen and 19 percent organic matter have occurred in the grain rotations. The smallest loss was in the 10-year rotation, with nitrogen and organicmatter losses of 14 percent and 5 percent, respectively.
At Indian Head, Saskatchewan (30), wheat yields after fallow showed no trends over a 40-year period. Wheat after wheat showed a downward trend. Wild oats was believed to be the cause, because this weed became a serious problem in later years.

At Brandon, Manitoba (30), yields of wheat on fallow were maintained. Yields were somewhat better in the manured rotation than those in the nonmanured rotation, but yield increases were not enough to pay the cost of manure application. Yields of second and third crops after fallow were seriously affected by infestations of wild oats in later years.

Hill (30) concluded that the wheat, fallow system could be continued profitably in western Canada for many years provided erosion and weeds were controlled.

Newton and coworkers (62), in comparing virgin and cultivated soils, reported on the analysis of soil samples from 85 locations in Alberta, Saskatchewan, and Manitoba. Average period of cultivation was 22 years. Losses of organic carbon and nitrogen from the surface 6 inches of Brown, Dark Brown, and Black soils were similar. Organic carbon loss was 20 percent of the original content, and nitro-

\section{TABLE 37.-Long-term and 1941-50 average yields from continuous wheat} and fallow, wheat rotations, Lethbridge, Alberta ${ }^{1}$

\begin{tabular}{|c|c|c|}
\hline \multirow{2}{*}{ Rotation } & \multicolumn{2}{|c|}{$\begin{array}{l}\text { Average grain yield, per } \\
\text { acre, for- }\end{array}$} \\
\hline & $1912-51$ & $1941-50$ \\
\hline $\begin{array}{l}\text { Continuous wheat } \\
\text { Alternate wheat and fallow } \\
\text { Wheat, wheat, fallow } \\
\text { 10-year including alfalfa }\end{array}$ & $\begin{array}{l}\text { Bushels } \\
12.2 \\
27.1 \\
225.8 \\
225.4\end{array}$ & $\begin{array}{l}\text { Bushels } \\
\quad 12.1 \\
27.1 \\
228.3 \\
225.5\end{array}$ \\
\hline
\end{tabular}

1 Data from Hill (so).

Fallow wheat ylelds. 
gen loss was 18 percent. Losses of organic carbon and nitrogen from the 6 - to 12 -inch depths were small as compared with the original content. Losses were comparable with those reported by Haas and coworkers (27) for the U.S. northern Great Plains.

Newton and coworkers (62) calculated that one-third to one-half of the nitrogen lost from the surface 6 inches of cultivated soil in the Brown, Dark Brown, and Black soil zones was removed by crops. Grain and fallow rotations carried on for 25 to 30 years at Lethbridge and Indian Head resulted in large losses of organic carbon and nitrogen. Comparable rotations that included legumes or legumes and grasses and barnyard manure caused smaller losses of organic carbon and nitrogen.

The value of sweetclover as a dryland green-manure crop has been studied at Lethbridge, Alberta, for 30 years $(6)$. On fallow, wheat, wheat rotations, average yield of fallow wheat was higher from cloverless fallow than that where clover fallow was used. Average yields of second-year wheat were almost 2 bushels per acre higher from rotations that included clover than from those that did not include clover. During years of good moisture, this difference was more than 2 bushels. The average yield of wheat after clover fallow was much higher where the clover was plowed for fallow before May 15 than where plowing was delayed until after the clover was more mature.

\section{Chemical and Physical Effects of Legumes and Grasses on Soils}

Lehane and Staple (45) investigated the effects of crested wheatgrass on physical and chemical characteristics of soil. This investigation was to determine the beneficial effects of a large-scale regrassing program that had been carried out in the Brown soil zone of western Canada from 1937 to 1942 . Crested wheatgrass had germinated and survived better than other grasses and had proved to be a relatively efficient user of moisture under dry conditions. Coarse-, medium-, and fine-textured soils were sampled. Composite samples to a depth of 6 inches were taken from crested wheatgrass sod and from nearby cultivated land. Effects of crested wheatgrass on seven soil properties were tabulated (table 38 ).

The data indicate that crested wheatgrass had beneficial effects on coarse- and medium-textured soils. Decomposed and undecomposed sod samples showed a large increase in field capacity, a smaller increase in permanent wilting point, and a net increase in available moistureholding capacity. Bulk density was decreased and carbon and nitrogen increased. The authors suggested that part of the organic carbon increase and most of the nitrogen increase may have been caused by soil drift material blown onto the sod land. Grass increased dry aggregation of coarse-textured soils and increased both the dry and wet aggregation of mediumtextured soils. Fine-textured soils showed little benefit from the grass.

Stevenson and White (7/) studied root production of several perennial grasses at Saskatoon, Saskatchewan. Two objectives of the study were to determine the relative root production of slender wheatgrass, crested wheatgrass, and bromegrass and the time required for satisfactory restoration of root fiber to a cultivated soil. All three grasses increased root production each year for 5 years. Five-year stands of crested wheatgrass added more than 3 tons of roots per acre, which was about one-half the quantity of roots present in native prairie soil. Root yields of bromegrass and crested 
TABLE 38.-Effects of crested wheatgrass on 7 physical and chemical characteristics of coarse-, medium-, and fine-textured soils in southwestern Saskatchewan, $1942^{1}$

\begin{tabular}{|c|c|c|c|c|c|c|c|c|}
\hline $\begin{array}{c}\text { Type of soil and } \\
\text { treatment }\end{array}$ & $\begin{array}{l}\text { Field } \\
\text { capac- } \\
\text { ity }\end{array}$ & $\begin{array}{l}\text { Perma- } \\
\text { nent } \\
\text { wilting } \\
\text { point }\end{array}$ & $\begin{array}{l}\text { Avail- } \\
\text { able } \\
\text { mois- } \\
\text { ture } \\
\text { capac- } \\
\text { ity }\end{array}$ & $\begin{array}{c}\text { Bulk } \\
\text { densi- } \\
\text { ty }\end{array}$ & C & $\mathrm{N}$ & $\begin{array}{c}\text { Dry } \\
\text { sepa- } \\
\text { rates, } \\
>0.83 \\
\mathrm{~mm} .\end{array}$ & $\begin{array}{l}\text { Wet } \\
\text { sepa- } \\
\text { rates, } \\
>0.177 \\
\mathrm{~mm} .\end{array}$ \\
\hline & $\begin{array}{l}\text { Per- } \\
\text { cent }\end{array}$ & $\begin{array}{l}\text { Per- } \\
\text { cent }\end{array}$ & $\begin{array}{l}\text { Per- } \\
\text { cent }\end{array}$ & & $\begin{array}{l}\text { Per- } \\
\text { cent }\end{array}$ & $\begin{array}{l}\text { Per- } \\
\text { cent }\end{array}$ & $\begin{array}{l}\text { Per- } \\
\text { cent }\end{array}$ & $\begin{array}{l}\text { Per- } \\
\text { cent }\end{array}$ \\
\hline $\begin{array}{c}\text { Coarse-textured soils: } \\
\text { Cultivated land }\end{array}$ & 160 & 58 & & & 120 & & & \\
\hline Sod & $\begin{array}{l}\text { 10. } 0 \\
21.2\end{array}$ & $\begin{array}{l}5.2 \\
6.1\end{array}$ & $\begin{array}{l}10.8 \\
15.0\end{array}$ & $\begin{array}{l}\text { 1. } 43 \\
\text { 1. } 36\end{array}$ & $\begin{array}{l}1.30 \\
1.90\end{array}$ & 0. $\begin{array}{r}026 \\
.167\end{array}$ & $\begin{array}{l}\text { 15. } 1 \\
17.9\end{array}$ & $\begin{array}{l}61.6 \\
61.6\end{array}$ \\
\hline $\begin{array}{l}\text { Sod decomposed: } \\
5 \text { months }\end{array}$ & 21.3 & 5.9 & & 135 & 1. 66 & 160 & 226 & \\
\hline $\begin{array}{l}10 \text { months } \\
\text { Medium-textured }\end{array}$ & 21.4 & 6. 1 & 15. 4 & 1. 33 & $\begin{array}{l}1.00 \\
1.45\end{array}$ & .150 & $\begin{array}{l}22.0 \\
28.0\end{array}$ & $\begin{array}{l}61.6 \\
61.5\end{array}$ \\
\hline $\begin{array}{l}\text { Soils: } \\
\text { Cultivated land. }\end{array}$ & 25.8 & 9.3 & 16. 5 & 1. 23 & 2. 10 & .214 & 37.2 & 41.5 \\
\hline Sod & 29.1 & 10. 2 & 18.9 & 1. 16 & 2. 61 & .259 & 37. 3 & 50. 9 \\
\hline $\begin{array}{l}\text { Sod decompos } \\
5 \text { months. }\end{array}$ & 29.7 & 10.4 & 3 & 1. 12 & 2. 40 & 243 & & \\
\hline $\begin{array}{l}10 \text { months } \\
\text { ine-textured soils: }\end{array}$ & 29.9 & 10.8 & 19.1 & 1. 10 & 2. 33 & 238 & 49. 1 & 49. 9 \\
\hline Cultivated land.... & 40.4 & 18. 6 & 21.8 & 1.02 & 2. 08 & .214 & 65,4 & \\
\hline Sod - - & 40.6 & 19. 2 & 21. 4 & 1. 04 & 2. 16 & .207 & 64. 9 & $68.8^{7}$ \\
\hline $\begin{array}{l}\text { Sod de } \\
5 \mathrm{mo}\end{array}$ & 41.0 & 19.5 & 21.5 & 1. 02 & 2. 00 & 206 & & 68.2 \\
\hline 10 months & 40. 6 & 19. 6 & 21.0 & 1. 02 & 1. 92 & 201 & 71.8 & 70. 1 \\
\hline
\end{tabular}

1Data from Lehane and Staple (45).

wheatgrass were similar. Slender wheatgrass produced about one-half as much root material as the other two grasses and was considered of little value in improving soil structure. Crested wheatgrass was superior to bromegrass in increasing the size of soil aggregates. The authors concluded that a 5-year stand of crested wheatgrass would provide satisfactory restoration of soil structure to cultivated clay loam soil. There was no indication of the duration of this beneficial effect.

Effect of adding crop residues to two types of soils in pot cultures was studied at Swift Current, Saskatchewan (5). The experiment was carried on for 5 years. One treatment consisted of one crop of wheat per year grown on the wheat, fallow rotations. The other treat- ment consisted of a similar rotation but with the addition of finely ground straw in amounts equal to the crop produced. Data on the organic matter and nitrogen losses are tabulated (table 39).

Losses of organic matter and nitrogen were reduced by adding straw to the soil. The authors postulated that similar beneficial effects would occur under field conditions.

\section{Summary}

Green manuring was not recommended for Brown and Dark Brown soils in the Prairie Provinces. Usually the small-grain yields after green-manure fallow were less than those after ordinary fallow.

Legume and grass crops in rotations reduced yields of succeeding 
TABLE 39.-Losses of organic motter and nitrogen from virgin and cultivated soil of 2 types, with and without residue, during 5 years of pot culture, Swift Current, Saskatchewan, $1954^{1}$

\begin{tabular}{|c|c|c|c|c|}
\hline \multirow{2}{*}{ Soil } & \multicolumn{2}{|c|}{$\begin{array}{l}\text { Loss in organic } \\
\text { matter- }\end{array}$} & \multicolumn{2}{|c|}{ Loss in nitrogen- } \\
\hline & $\begin{array}{l}\text { Without } \\
\text { residue }\end{array}$ & $\begin{array}{l}\text { With } \\
\text { residue }\end{array}$ & $\begin{array}{l}\text { Without } \\
\text { residue }\end{array}$ & $\begin{array}{l}\text { With } \\
\text { residue }\end{array}$ \\
\hline $\begin{array}{l}\text { Wood mountain clay loam: } \\
\text { Virgin } \\
\text { Cultivated. } \\
\text { Sceptre clay: }\end{array}$ & $\begin{array}{r}\text { Percent } \\
26.9 \\
21.6\end{array}$ & $\begin{array}{r}\text { Percent } \\
20.3 \\
17.7\end{array}$ & $\begin{array}{l}\text { Percent } \\
23.2 \\
21.3\end{array}$ & $\begin{array}{r}\text { Percent } \\
19.4 \\
17.9\end{array}$ \\
\hline Virgin & $\begin{array}{l}\text { 16. } 9 \\
\text { 12. } 4\end{array}$ & $\begin{aligned} 12.8 \\
9.3\end{aligned}$ & $\begin{array}{l}21.4 \\
21.3\end{array}$ & $\begin{array}{l}20.1 \\
15.4\end{array}$ \\
\hline
\end{tabular}

1 Data from (5).

crops at Lethbridge, Alberta, in the Chestnut soil zone and at Swift Current, Saskatchewan, in the Brown soil zone.

On Chernozem soils at Indian Head, Saskatchewan, and Brandon, Manitoba, legume-grass rotations produced higher yields than straightgrain rotations in a 10 -year period. Nitrogen fertilizer also increased grain yields, but there is insufficient data to indicate whether or not nitrogen would substitute for legumes and grasses in rotation on Chernozem soils.

Cropping caused substantial nitrogen and carbon losses. Legumes and grasses in rotations reduced but did not eliminate these losses.

Yields of fallow wheat have not declined with years of cropping on Brown, Dark Brown, and Chernozem soils. Yields of continuous wheat have declined to some extent in the more humid areas. Part of this decline was attributed to weed problems.
In 1954, Hill (30) concluded that the wheat, summer fallow system of cropping can profitably be continued in Western Canada for many years provided erosion and weeds are controlled.

In southwestern Saskatchewan, crested wheatgrass increased the water-holding capacity, carbon and nitrogen content, and aggregation of coarse- and medium-textured soils. Grass had little effect on fine-textured soils.

At Saskatoon, Saskatchewan, a 5-year stand of crested wheatgrass added more than 3 tons of root fiber to a cultivated clay loam soil. This restored soil structure to a satisfactory condition. Duration of this effect after the grass was plowed was not reported.

The addition of crop residues to soil in pot cultures reduced losses of organic matter and nitrogen. The authors postulated that similar benefits would occur under field conditions. 


\section{SUMMARY AND CONCLUSIONS}

In the drier areas of the Chernozem and in all the Chestnut and Brown soil zones of the United States and Canada, legumes and grasses, used as green-manure, hay, or pasture crops, usually depress the yields of the crops immediately following. Yield reductions are commonly associated with depleted soil-moisture reserves. Even if the land is fallowed before planting the following crop, yields are frequently not increased over those with ordinary fallow.

Along the eastern edge of the northern and central Great Plains, where annual precipitation is greater, legumes in rotation increase yields of corn and small grain in years of average or aboveaverage precipitation. In dry years, grain yields may be depressed by dry soil conditions after legumes.

The increased crop yjelds in areas of higher rainfall are attributed to the addition of nitrogen from the legume rotation. Limited data indicate that inorganic nitrogen is usually more efficient than legume nitrogen in increasing crop yields. More research data are needed to compare legume and inorganic nitrogen sources. Based on yields of following crops, the average legume inorganic nitrogen equivalent is estimated to be 30 to 40 pounds per acre per year. Values vary according to legume-growing conditions. This amount of nitrogen is probably not enough to meet the nitrogen requirements of grain crops in 3- and 4-year rotations. Supplemental nitrogen will almost certainly be needed for optimum crop production.

From the standpoint of increasing yields of following crops, available data indicate little justification for growing legumes and grasses in short rotation on class I, II, and III land ${ }^{8}$ in the northern and central
Great Plains.

Available research data were examined to determine whether or not water was being lost through deep percolation with existing cropping systems. If water was being lost, deeper rooted crops could be grown to use this water. In 1939 (12) data from Havre, Mont., Mandan, N. Dak., North Platte, Nebr., Hays and Colby, Kans., showed that the annual cropland cycle of water charge and discharge was, generally, confined to the root zone and that no water was moving to the underlying strata.

At both Lincoln, Nebr., and Manhattan, Kans., alfalfa used soil moisture to at least 30 feet when moisture was available from the surface downward. When deep soil moisture reserves were depleted at Lincoln, this moisture was not restored on medium- to heavy-textured soils under continuous cereal cropping. Five years of continuous fallow rewet the soil to only 11 feet.

At Manhattan, 2 years of fallow restored deep subsoil moisture reserves that had been depleted by alfalfa. Cereal cropping restored deep soil moisture reserves after 12 years (1938 to 1949). During one 4-year period, total precipitation exceeded average precipitation by 36.6 inches. Soil-moisture samples were not taken during this period, but it seems probable that much of the deep moisture restoration may have been during this period. Since precipitation at Lincoln and Manhattan is greater than in the Plains, it seems probable that water is not being lost to the water table on

${ }^{8}$ Land-capability classes I, II, and III are explained by Steele (76) as follows: Class I land is good land with few management limitations. Class II land has moderate limitations. Some easily applied conservation practices are necessary. Class III land has severe limitations. Continuous cultivation is possible if these limitations are handled properly. 
most medium- and fine-textured cultivated soils of the northern and central Great Plains.

Data are inadequate, but it seems probable that subhumid sandy lands are the only cultivated areas in the northern and central Great Plains where water may be moving to the water table. Some of the sandy cultivated soils of northeastern $\mathrm{Ne}$ braska and the Great Bend area of Kansas are probably losing some precipitation to the water table. Alfalfa would be a good crop to grow to make use of this water. Sweetclover has been shown to use soil moisture to 9 feet in 1 year and 14 feet in 2 years. Grasses are comparatively shallow rooted and seldom deplete soil moisture below 6 feet.

When grown for several years, grasses maintain or may increase soil nitrogen and organic matter. Nitrogen applications may increase nitrogen buildup, but seem to have little effect on accumulation of organic matter. Alfalfa grown for several years usually increases soil nitrogen and organic matter. Where legumes and grasses are grown for less than 1 year, chemical and physical soil effects are usually not measurable.

Several dryland experiment stations have grown legumes and grass for 3 years in 6-year rotations. Nitrogen and carbon losses from the soil have been reduced compared with nonlegume, grass rotations. Reductions in nitrogen losses were due to reduced runoff and erosion and to legume-nitrogen additions.

Sweetclover, field peas, and rye have been used in a green-manure fallow system once in 4 years at several dryland experiment stations in the northern and central Great Plains. Compared with non-greenmanure cropping systems, nitrogen and carbon losses from the soil were not significantly reduced.
When grown for several years, grasses decrease bulk density of the surface soil, increase infiltration, improve aggregation, and reduce erosion. Effect of legumes on the physical condition of the soil appears to be minor. Fourteen years of sweetclover, fallow rotation at Hays, Kans., did not increase surface-soil aggregation appreciably.

Data from Kansas, Nebraska, North Dakota, and southwestern Saskatchewan indicate that 3 to 5 years of grass substantially improves soil structure. In southwestern Saskatchewan, crested wheatgrass had a beneficial effect on coarse- and medium-textured soils, but it had little effect on fine-textured soils. Data from Hays, Kans., indicate that 25 to 30 years of buffalograss are necessary to restore aggregation of a cultivated soil to the same level as native pasture. Limited tests in Nebraska and Kansas indicate that buffalograss is one of the best grasses for soil-aggregate formation and stability.

Beneficial effects of grass appear to be rather shortlived. Data from Mandan, N. Dak., indicate that 75 to 95 percent of grass roots in the surface 6 inches of soil had decomposed $2 \frac{1}{2}$ years after plowing. At Lincoln, Nebr., water-stable aggregation for all grasses except buffalograss had decreased 70 percent 2 years after plowing. Buffalograss aggregation decreased 50 percent. Structural improvement under grass appears to be considerably slower than structural deterioration after the grass is plowed.

Improved soil physical conditions have seldom increased crop yields in the northern and central Great Plains. This probably indicates that physical conditions are not limiting crop production.

Legumes and grasses are effective in reducing wind and water erosion. Decomposing legume and 
straw residues decrease erosion by increasing nonerodible aggregates in soil. After residues are decomposed, there is evidence that wind erosion may be aggravated, because soil structure breaks down into wind-erodible aggregates.

Where present cropping systems result in greater than allowable soil losses, ${ }^{9}$ a change in cropping system is needed. Excessive erosion eventually decreases yields. Incorporating legumes and grasses in the cropping system is an effective way to reduce soil losses. Legumes and grasses are well adapted to subhumid class III lands, ${ }^{10}$ such as in northeastern

9 Klingebiel, A. A. SOIL FACTOR AND SOIL LOSS TOLERANCE. In Soil Loss Prediction-North Dakota, South Dakota, Nebraska, and Kansas., pp. 18-19. Soil Conserv. Serv. (Report presented at Soil-Loss Prediction Workshop, Lincoln, Nebr., May 8-9, 1961.)

10 See footnote 8, p. 58 .
Nebraska, because of continuous need for wind and water-erosion protection. On such lands, commercial nitrogen to supplement legume nitrogen may be necessary for optimum crop production.

Legumes and grasses are valuable crops in themselves. They are an essential part of any livestock enterprise.

This review brings out the fact that not enough research work has been done to assess completely the effects of legumes and grasses under all soil and climatic conditions of the northern and central Great Plains. Historically, legumes- and grassrotation experiments were mostly located on favorable sites. Erosion effects cannot be studied adequately under these conditions. Even now (1963), few rotation experiments are designed to study the Jongtime effects of soil erosion

\section{LITERATURE CITED}

(1) Army, T. J., and Hide, J. C.

1959. EFFECTS OF GREEN MANURE CROPS ON DRYLAND WHEAT PRODUCTION

(2) BeLl, M. A. in the great plains of montana. Agron. Jour. 51: 196-198.

1937. THE EFFECT OF TILLAGE METHODS, CROP SEQUENCE, AND DATE OF SEEDING UPON THE YIELD AND QUALITY OF CEREALS AND OTHER CROPS GROWN UNDER DRYLAND CONDITIONS IN NORTH-CENTRAL Montana. Mont. Agr. Expt. Sta. Bul. 336, 100 pp.

(3) Brandon, J. F., and Mathews, O. R.

1944. DRYLAND ROTATIONS AND TILLAGE EXPERIMENTS AT THE AKRON (COlORAdo) Field Station. U.S. Dept. Agr. Cir. 700, 53 pp.

(4) Bray, J. O., and Schnittker, J. A.

1956. Legumes or commercial fertilizers? Kans. Agr. Expt. Sta. Bul. $384,16 \mathrm{pp}$.

(5) Canada Departiment of Agriculture.

1956. SoIl FERTILITY. Canada Expt. Farm Soil Res. Lab. Swift Current (Sask.) Prog. Rpt. 1948-54: 27-43.

(6)

1959. RESEARCH HIGHLIGHTS [FOR] 1958. Canada Expt. Farm Lethbridge (Alberta) Lith. Mimeo. 10: 6-8.

(7) Canada Department of Mines and Technical Surveys.

1957. SOIL REgIONS 35 . Atlas of Canada.

(8) Carpenter, R. W.

1948. EFFECT OF ORGANIC AMENDMENTS ON CROP YIELDS AT MANDAN, NORTh DAKOta. N. Dak. Expt. Sta. Bimo. Bul. 10, pp. 87-89.

(9) Chepil, W. S.

1955. FACTORS THAT INFLUENCE CLOD STRUCTURE AND ERODIBILITY OF SOII BY WIND: V. ORGANIC MATTER AT VARIOUS STAGES OF DECOMPOSITION. Soil Sci. 80: 413-421. 
(10) Chilcotт, E. C.

1931. THE RELATIONS BETWEEN CROP YIELDS AND PRECIPITATION IN THE GREAT PLAINS AREA. CROP ROTATIONS AND TILLAGE METHODS. U.S. Dept. Agr. Misc. Cir. 81, Sup. 1, 164 pp.

(11) Cole, J. S., Kelso, F. L., Russell, E. Z., and others.

1927. WORK OF THE UNITED STATES DRY-LAND FIELD STATION, ARDMORE, S. DAK., 1912 TO 1925. U.S. Dept. Agr. Tech. Bul. 17, 68 pp, and Mathews, O. R

1939. SUbSoIl MoISTURe under semiarid conditions. U.S. Dept. Agr. Tech. Bul. 637, $71 \mathrm{pp}$.

(13) Conlon, T. J., Douglas, R. J., and Moomaw, L.

1953. ROTATIONS AND TILLAGE INVESTIGATIONS AT THE DICKINSON EXPERIment station, dickinson, NORTH DaKota. N. Dak. Agr. Expt. Sta. Bul. 383, $126 \mathrm{pp}$.

(14) Doughty, J. L.

1948. THE Maintenance of ORganic Matter in the BRown solls. Sci. Agr. 28: 88-95.

(15) Duley, F. L.

1929. the effect of alfalfa on soll moisture. Amer. Soc. Agron. Jour, 21: 224-231,

(16)

1960. YIELDS ON DIFFERENT CROPPING SYSTEMS AND FERTILIZER TESTS UNDER StUbble MULChing and Plowing in Eastern nebraska. Nebr. Agr. Expt. Sta. Res. Bul. 190, 53 pp. 13: 554-557.

1955. FARMiNG WHERE RAINFALL IS $8-20$ INCHES A YEAR. In U.S. Dept. Agr. Yearbook "Water," pp. 407-415. and Domingo, C. E.

1949. EFfeCt of Grass on intake of Water. Nebr. Agr. Expt. Sta. Res. Bul. 159,15 pp. and Russel, J. C.

1948. Sweetclover in a stubble-mulch system. Soil Sci. Soc. Amer. Proc.

(20) Russel, J. C., Gooding, T. H., and Fox, R. L.

1953. SOIL CONSERVATION AND MANAGEMENT ON SANDY FARM LAND IN Northeast Nebraska. Nebr. Agr. Expt. Sta. Bul. 420, 39 pp.

(21) Fine, L. O., and CAMpbell, R. E.

1954. SoIl Experiments. S. Dak. Agr. Expt. Sta. Cir. 107, pp. 19-29.

(22) Fritschen, L. J., and HobBs, J. A.

1958. EFFECT OF CROP ROTATION AND FERTILIZER TREATMENT ON THE NITROgen and organic Carbon contents of a prairie soll. Soil Sci. Soc. Amer. Proc. 22: 439-441.

(23) Grandfield, C. O., and Metzger, W. H.

1936. RELATION OF FALLOW TO RESTORATION OF SUBSOIL MOISTURE IN AN OLD ALFALFA FIELD AND SUBSEQUENT DEPLETION AFTER RESEEDING. Amer. Soc. Agron. Jour. 28: 115-123.

(24) HAAS, H. J.

1955. CROPPING SYSTEMS INFLUENCE WHEAT AND CORN YIELDS AND NITROGEN LEVELS OF DRYLAND sorls. Soil and Water Conserv. Jour. 10: 152,

(25)

1955. EFFECT OF FERTILIZERS, AGE OF STAND, AND DECOMPOSITION ON WEIGHT OF GRASS ROOTS AND OF GRASS AND ALFALFA ON SOIL NITROGEN AND CARBON. Agron. Jour. 50: 5-9.

(26) and Bostwright, G. O.

1960. LET'S TAKE ANOTHER LOOK AT SUMMER FALLOW IN THE NORTHERN PLAINS. Soil and Water Conserv. Jour. 15: 176-179.

(27) Evans, C. E., and Miles, E. F.

1957. NITROGEN AND CARBON CHANGES IN GREAT PLAINS SOILS AS INFLUenced by CROpping and soil treatments. U.S. Dept. Agt. Tech.

Bul. 1164, 111 pp.
(28) Hansen, D., Seaman, A. E., and Kopland, D. V.

1933. AGRicultural inVestigations At THE HUNTLEy (MONTANA) FIELd Station, 1927-1930. U.S. Dept. Agr. Tech. Bul. 353, 50 pp.

(29) HiLL, K. W.

1954. THESE SOILS HAVE GROWN WHEAT FOR FIFTY YEARS. What's New in Crops and Soils $6(7): 14-15$. 
(30) HiLL, K. W.

1954. WHEAT YIELDS AND SOIL FERTILITY ON THE CANADIAN PRAIRIE AFTER A Half-century of farming. Soil Sci. Soc. Amei Proc. 18: 182-184.

(31) Новвs, J. А.

1953. REPLENISHMENT OF SOIL MOISTURE SUPPLY FOLLOWING THE GROWTH of ALFALFA. Agron. Jour. 45: 490-493.

(36) Hopkins, E. S., and Barnes, S.

1955. THE EFFECT OF CROP ROTATIONS AND SOIL TREATMENTS ON SOIL Productivity. Soil Sci. Soc. Amer. Proc. 19: 320-324.

1957. the winter wheat and grazing Region. In U.S. Dept. Agr. Yearbook "Soil," pp. 505-515. and Brown, P. L.

1957. Nitrogen Changes in CUltivated dRyland soils. Agron. Jour. 49: 257-260.

and Brown, P. L.

1957. NITROGEN AND ORGANIC CARBON CHANGES IN CULTIVATED WESTERN KanSAs soils. Kans. Agr. Expt. Sta. Tech. Bul. 89, 48 pp.

1928. CROP ROTATION AND SOIL MANAGEMENT FOR THE PRAIRIE PROVINCES. Canada Dept. Agr. (n.s.) Bul. 98, 53 pp.

(38) JACKS, G. V and LEAHEY, A.

1944. CROP ROtations in THe PRAIRIE Provinces. Canada Dept. Agr. Farmers' Bul. 124, 70 pp.

1944. The influence of herbage rotations on the sorl. Imp. Agt. Bur. Joint Pub. 6: $42-55$.

(39) Kresselbach, T. A., Anderson, A., and Russel, J. C.

1934. SUBSOIL MOISTURE AND CROP SEQUENCE IN RELATION TO ALFALFA PRODUCtion. Amer. Soc. Agron. Jour. 26: 422-442.

(40) and LYNESS, W. E.

1952. Crop rotation experiments. Nebr. Agr. Expt. Sta. Bul. 416, 33 pp.

(41) Russel, J. C., and Anderson, A.

1929. THE SIGNIFICANCE OF SUBSOIL MOISTURE IN ALFALFA PRODUCTION. Amer. Soc. Agron. Jour. 21: 241-268.

(42) Kingsley, Q. S., and Shubeck, F. E.

1959. fertility and cultural Practices. S. Dak. Agr. Expt. Sta. Agron. and Plant Path. Pam. 52: 7-12.

(43) and SHUBECK, F. E.

1959. Fer illity and cultural practices experiments. S. Dak. Agr. Expt. Sta. Agron. and Plant Path. Pam. 53: 6-10.

(44) Kuska, J. B., and Mathews, O. R.

1956. DRYLAND CROP-ROTATION AND TILLAGE EXPERIMENTS AT THE COLBY (kansas) branch experiment station. U.S. Dept. Agt. Cir. 979, $87 \mathrm{pp}$.

(45) Lehane, J. J., and Staple, W. J.

1943. THE EFFECT OF CRESTED WHEATgRASS ON SOME PHYSICAL AND CHeMical CHARACteristics of the soil. Sci. Agr. 23: 509-517.

(46) McCalla, T. M., and Russel, J. C.

1948. NITRATE PRODUCTION AS AFFECTED BY SWEETCLOVER RESIDUES LEFT ON THE SURFACE OF THE SOIL. Amer. Soc. Agron. Jour. 40: 411-421.

(47) McHenry, J. R., Alexander, L. T., and Zook, L. L.

1946. CARBON AND NITROGEN CONTENTS OF A CHERNOZEM SOIL AS AFFECTED BY AGE OF PERennial Grass sod. Soil Sci. Soc. Amer. Proc. 11: $407-412$.

(48) and Newell, L. C.

1947. INFLUENCE OF SOME PERENNIAL GRASSES OA THE ORGANIC MATTER CONTENT AND STRUCTURE OF AN EASTERN NEBRASKA FINE-TEXTURED sorl. Amer. Soc. Agron. Jour. 39: 981-994.

(49) and Newell, L. C.

1949. RESIDUAL EFFECT OF SOME PERENNIAL GRASSES ON THE STRÚCTURE of an EASTERn NEBRASKa FINE-TEXTURED soll. Agron. Jour. 41: 76-78.

(50) Zook, L. L., and RhoAdes, H. F.

1950. PORE SPACE AND AGGREGATION IN A CHERNOZEM SOIL AS AFFECTED BY AGE OF PERenNial grass SOD. Agron. Jour. 42: 377-380. 
(51) MA.rhews, O. R., and CLARK, V. I.

1937. RESULTS OF FIELD, SHELTERBELT, AND ORCHARD INVESTIGATIONS AT THE UNITED STATES DRYLAND FIELD STATION, ARDMORE, S. DAK., 1911-32. U.S. Dept. Agr. Cir. 421, 48 pp.

(52) and Cole, J. S.

1938. SPECIAL DRY-Farming PRoblems. In U.S. Dept. Agr. Yearbook, "Soils and Men," pp. 679-692.

(53) Mazurak, A. P., and Conard, E.

1959. RATES OF WATER ENTRY IN THE THREE GREAT SOIL GROUPS AFTER SEVEN Years IN GRASSES AND LegUMes AND sMall Grains. Agron. Jour. 51: 264-267.

(54)

METZGeR, W. H.

1935. THE RESIDUAL EFFECT OF ALFALFA CROPPING PERIODS OF VARIOUS LENGTHS UPON THE YIELD AND PROTEIN CONTENT OF SUCCEEDING wheat Crops. Amer. Soc. Agron. Jour. 27: 653-659.

(56)

(57) Moomaw, L.

1939. NITROGEN AND ORGANIC CARBON OF SOILS AS INFLUENCED BY CROPping systems and soil treatments. Kans. Agr. Expt. Sta. Tech. Bul. 45,36 pp.

1925. TILLAGE AND ROTATION EXPERIMENTS AT DICKINSON, HETTINGER, AND Williston, N. DaK. U.S. Dept. Agr. Dept. Bul. 1293, 23 pp.

(58) MYeRs, H. E.

1936. THE DIFFERENTIAL INFLUENCE OF CERTAIN VEGETATIVE COVERS ON DEEP sUbsoll Molsture. Amer. Soc. Agron. Jour. 28: 106-114.

(59) Hallsted, A. L., Kuska, J. B., and HaAs, H. J.

1943. NITROGEN AND CARBON CHANGES IN SOILS UNDER LOW RAINFALL AS INFLUENCED BY CROPPING SYSTEMS AND SOIL TREATMENT. Kans. Agr. Expt. Sta. Tech. Bul. 56, 52 pp.

(60) - and Mrers, H. G.

1944. SOIL AGGREGATION AS A FACTOR IN YIELDS FOLLOWING ALFALFA. Amer. Soc. Agron. Jour. 36: 965-969.

(61) Nelson, A. L.

1950. methods of tillage for winter wheat. Wyo. Agr. Expt. Sta. Bul. 300, 28 pp.

(62) Newton, J. D., Wyatт, F. A., and Brown, A. L.

1945. EFFECTS OF CULTIVATION AND CROPPING ON THE CHEMICAL COMPOSITION OF SOME WESTERN CANAdA PRAIRIE PROVINCE SOILS. . . Sci. Agr. 25: 718-737.

(63) Norum, E. B., Krantz, B. A., and HaAs, H. J.

1957. THE NORTHERN Great PLAINS. In U.S. Dept. Agr. Yearbook "Soil," pp. 494-505.

(64) Olmstead, L. B.

1946. THE EFFECT OF LONG-TIME CROPPING SYSTEMS AND TILLAGE PRACTICES UPON soll aggregation at haYs, Kansas. Soil Sci. Soc. Amer. Proc. 11: 89-92.

(65) Osenbrug, A., and Mathews, O. R.

1951. DRY-LAND CROP PRODUCTION ON THE CLAY SOILS OF WESTERN SOUTH Daкота. S. Dak. Agr. Expt. Sta. Cir. 85, 22 pp.

(66) Pieters, A. J.

1917. GREEN MANURING. A REVIEW OF THE AMERICAN EXPERIMEN' station literature. Amer. Soc. Agron. Jour. 9: 62-82, 109-126, $162-190$.

(67) Post, A. H., and Army, T. J.

1956. WHEAT YIELDS ON MONTANA DRYLANDS-ARE THEY GOING UP OR Down? Mont. Farmer-Stockman 43 (10): 1, 6.

(68) Puhr, L. F., Brage, B., Shubeck, F., and others.

1957. SOUth DaKota Fertilizer experiments. S. Dak. Agr. Expt. Sta Agron. Pam. 41, 27 pp.

(69) and Worzella, W. W.

1956. FERTILITY AND MAINTENANCE AND MANAGEMENT OF SOUTH DAKOTA sorl. S. Dak. Agr. Expt. Sta. Cir. 92, 24 pp. 
(70) Russel, J. C.

1929. ORGANIC MATTER PROBLEMS UNDER DRY-FARMING Conditions. Amer. Soc. Agron. Jour. 21: 960-969.

(71) Sarvis, J. T., and Thysell, J. C.

1936. CROP ROTATIONS AND TILLAGE EXPERIMENTS AT THE NORTHERN Great Plains Field station, Mandan, N. Dak. U.S. Dept. Agr. Tech. Bul. 536, $76 \mathrm{pp}$.

(72) Shubeck, F. E., and Kingsley, Q. S.

1958. Fertility and CUltural Practice experiments. S. Dak. Agr. Expt. Sta. Agron. and Plant Path. Pam. 42: 19-29.

(73) - and Kingsley, Q. S

1958. Fertility and CUltural practice experiments. S. Dak. Agr, Expt. Sta. Agron. and Plant Path. Pam. 43: 25-32.

(74) and Kingsley, Q. S.

1958. Fertility and cUltural practice experiments. S. Dak. Agr, Expt. Sta. Agron. and Plant Path. Pam. 48: 6-11.

(75) and Kingsley, Q. S.

1958. FERTILITY AND CUltural PRACTICE EXPeriments. S. Dak. Agr. Expt. Sta. Agron. and Plant Path. Pam. 49: 6-11.

(76) Steele, J. G.

1951. The Measure of oUR LAND. U.S. Soil Conserv. Serv. PA-128, 17 pp.

(77) Stevenson, T. M., and White, W. J.

1941. ROOT Fibre production of SOME PERENNial grasses. Sci. Agr. 22: 108-118.

(78) Stickler, F. C., Shrader, W. D., and Johnson, I. J.

1959. COMPARATIVE VALUE OF LEGUME AND FERTILIZER NITROGEN FOR CORN PRODUCTION. Agron. Jour. 51: 157-160.

(79) Towle, R. S.

1925. WORK OF THE SHERIDAN FIELD STATION FOR THE SEVEN YEARS 1917 TO 1923, INCLusive. U.S. Dept. Agr. Dept. Bul. 1306, 31 pp.

(80) Trsdal, H. M., and Kiesselbach, T. A.

1941. alfalfa in nebraska. Nebr. Agr. Expt. Sta. Bul. 331, 68 pp.

(81) U.S. Soll Conservation Service.

1950. Problem areas of soll conservation (MaP). U.S. Dept. Agr. Soil Conserv. Serv.

(82) Westin, F. C., Puhr, L. F., and Buntley, G. J.

1959. Solls of SoUth DaKota. S. Dak. Agr. Expt. Sta. Soil Survey Ser. No. 3, $34 \mathrm{pp}$.

(83) Worzella, W.' W., Puhr, L. F., Adams, M. W., and others.

1957. RESEARCH IN CROPS AND SOILS-A PROGRESS REPORT. S. Dak. Agr. Expt. Sta. Cir. 136, 23 pp.

(84) Young, R. A., Zubriski, J. C., and N * M, E. B.

1960. INFLUENCE OF LONG-TIME FERIIL TY MANAGEMENT PRACTICES ON Chemical and physical properties of a fargo clay. Soil Sci. Soc. Amer. Proc. 24: 124-128.

(85) Zook, L. L.

1923. DRY FARMiNG INVESTIGATIONS AT THE SCOTTSBLUFF SUBSTATION. Nebr. Agr. Expt. Sta. Bul. 192, 23 pp.

(86) and Weakley, H. E.

1950. CROP ROTATIONS AND TILLAGE EXPERIMENTS AT THE NORTH PLATTE (NEBR.) SUBStation, 1907-1934. U.S. Dept. Agr. Tech. Bul. 1007, 78 pp. 



